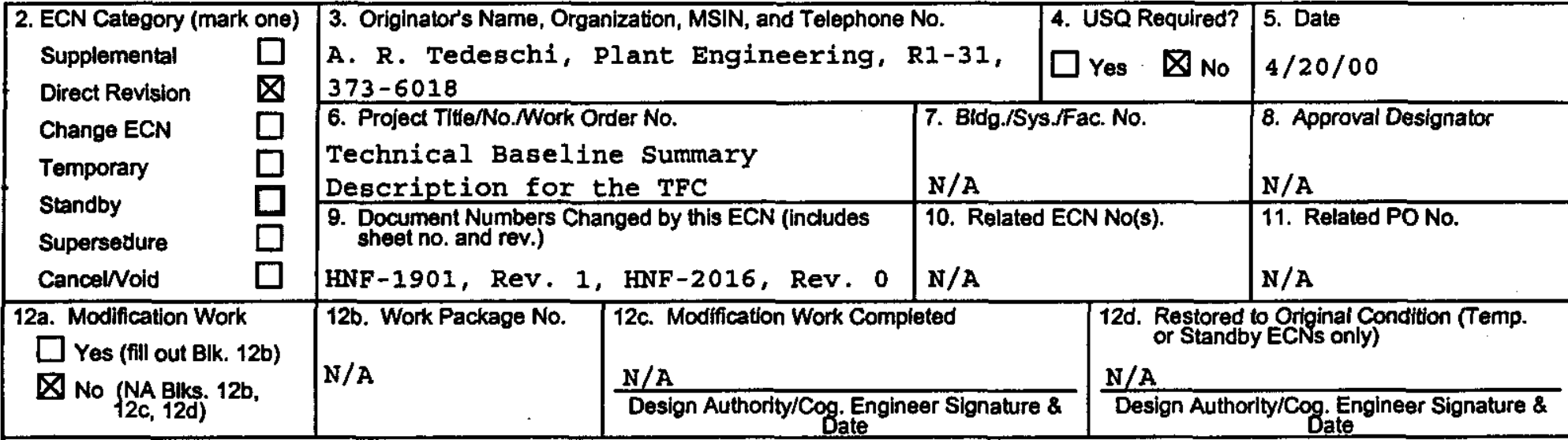

13a. Description of Change

13b. Design Baseline Document? $\square$ Yes $\bigotimes$ No

1) New technical baseline definitions and resulting data were incorporated.

2) Mission scope discussiion was minimized and references to upper-level documents were added.

3) Technical information and references were updated.

4) This document also supercedes HNF-2016, "TWRS Technical Baseline Summary Description"

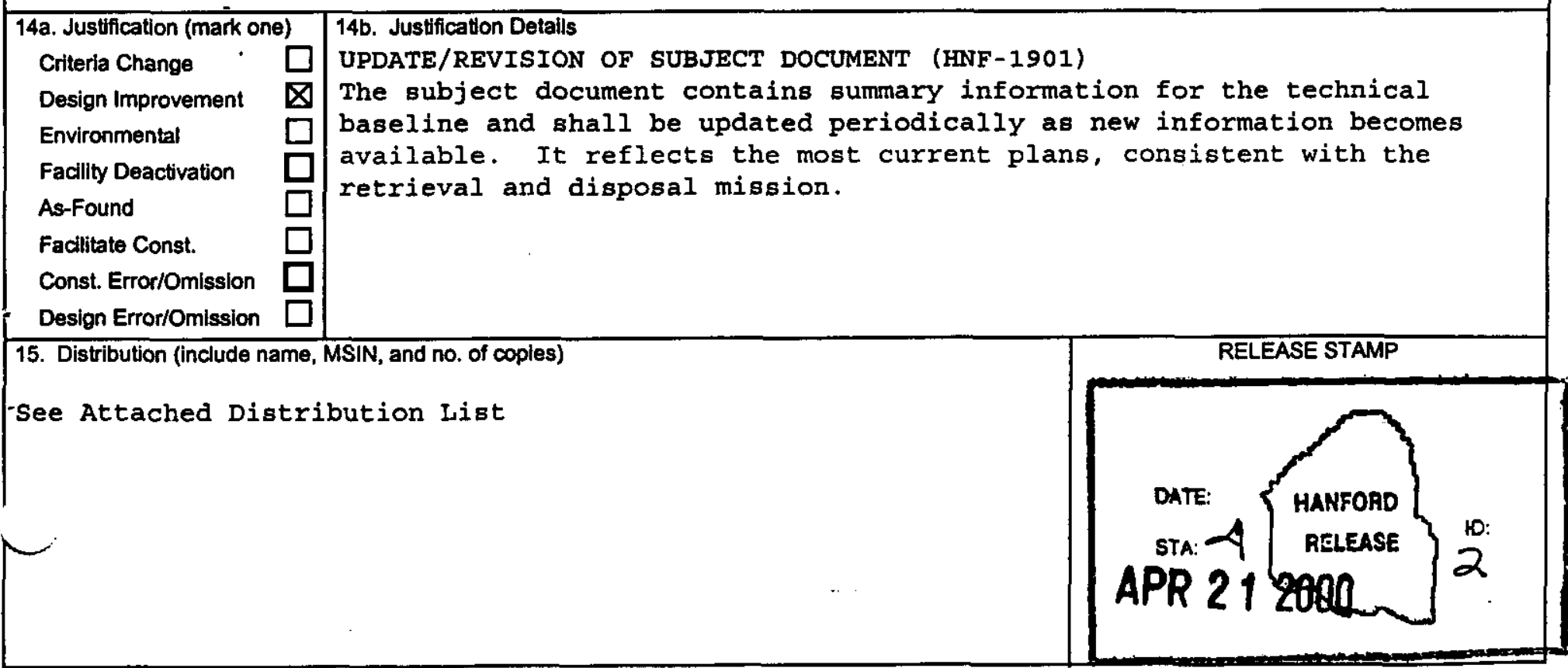




\begin{tabular}{|c|c|c|c|c|c|c|c|}
\hline \multicolumn{4}{|c|}{ ENGINEERING CHANGE NOTICE } & \multicolumn{2}{|c|}{ Page 2 of 2} & \multicolumn{2}{|c|}{$\begin{array}{l}\text { 1. ECN (use no. from pg. 1) } \\
660089\end{array}$} \\
\hline \multirow{3}{*}{$\begin{array}{l}\text { 16. Design Verfication } \\
\text { Required } \\
\square \text { Yes } \\
\bigotimes \text { No }\end{array}$} & \multicolumn{5}{|c|}{ 17. Cost Impact } & \multicolumn{2}{|c|}{ 18. Schedule Impact (days) } \\
\hline & \multicolumn{2}{|c|}{ Addironal $\square \leqslant \underline{N} / \mathrm{A}$} & \multicolumn{2}{|c|}{ Additional $\square \leqslant \underline{N / A}$} & & \multicolumn{2}{|c|}{ Improvement $\square \mathrm{N} / \mathrm{A}$} \\
\hline & \multicolumn{2}{|c|}{ Savings $\square \leqslant N / A$} & Savings $\square$ & \multicolumn{2}{|l|}{$\mathrm{N} / \mathrm{A}$} & Delay & $\mathrm{N} / \mathrm{A}$ \\
\hline \multicolumn{8}{|c|}{$\begin{array}{l}\text { 19. Change Impact Review: Indicate the related documents (other than the engineering documents identified on Side 1) that will be affected by } \\
\text { the change described in Block } 13 \text {. Enter the affected document number in Block } 20 \text {. }\end{array}$} \\
\hline \multicolumn{2}{|l|}{ SDD/DD } & $\square$ & Seismic/Stress Analysis & $\square$ & \multicolumn{2}{|c|}{ Tank Calibration Manual } & $\square$ \\
\hline \multicolumn{2}{|c|}{ Functional Design Criteria } & & Stress/Design Report & $\square$ & \multicolumn{2}{|c|}{ Health Physics Procedure } & $\square$ \\
\hline \multicolumn{2}{|c|}{ Operating Specification } & & Interface Control Drawing & $\square$ & \multicolumn{2}{|c|}{ Spares Multiple Unit Listing } & $\square$ \\
\hline \multicolumn{2}{|c|}{ Criticality Specification } & & Calibration Procedure & $\square$ & \multicolumn{2}{|c|}{ Test Procedures/Specification } & $\square$ \\
\hline \multicolumn{2}{|c|}{ Conceptual Design Report } & & Installation Procedure & $\square$ & \multicolumn{2}{|c|}{ Component Index } & $\square$ \\
\hline \multicolumn{2}{|l|}{ Equipment Spec. } & & Maintenance Procedure & $\square$ & ASME C & ded Item & $\square$ \\
\hline Const. Spec. & [ & & Engineering Procedure & $\square$ & Human 1 & actor Consideration & $\square$ \\
\hline Procurement Spec & [ & & Operating Instruction & $\square$ & Comput & Software & $\square$ \\
\hline Vendor Informatior & [ & & Operating Procedure & $\square$ & Electric & ircuit Schedule & $\square$ \\
\hline OM Manual & [ & & Operational Safety Requirement & $\square$ & ICRS Pr & cedure & $\square$ \\
\hline FSAR/SAR & - & & IEFD Drawing & $\square$ & Process & Control ManuaV/Plan & $\square$ \\
\hline Safety Equipment & it & & Cell Arrangement Drawing & $\square$ & Process & Flow Chart & $\square$ \\
\hline Radiation Work $\mathrm{Pe}$ & it & & Essential Material Specification & $\square$ & Purchas & Requisition & $\square$ \\
\hline Environmental Imp & t Statement & & Fac. Proc. Samp. Schedule & $\square$ & Tickler $F$ & & $\square$ \\
\hline Environmental Res & $t$ & & Inspection Plan & $\square$ & NONE & & $凶$ \\
\hline Environmental Per & [ & & Inventory Adjustment Request & $\square$ & & & $\square$ \\
\hline
\end{tabular}

20. Other Affected Documents: (NOTE: Documents listed below will not be revised by this ECN.) Signatures below indicate that the signing organization has been notified of other affected documents listed below.

Document Number/Revision

$\mathrm{N} / \mathrm{A}$
Document Number/Revision

$\mathrm{N} / \mathrm{A}$

Document Number/Revision

$\mathrm{N} / \mathrm{A}$

21. Approvals

Signature.

Design Authority 8

Cog. Eng. AR Tedeschi CAld halici

Cog. Mgr. RE Raymond $D E$ 4.21-00.

QA

Safety

Environ.

Other
Date

$4-21-00$
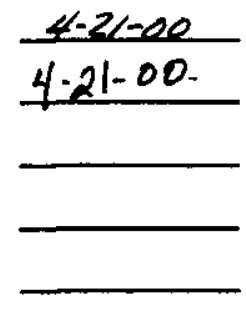

Signature

Date
Design Agent

PE

QA

Safety

Design

Environ.

Other

\section{DEPARTMENTLOE ENERGY}

Stgnature or a Control Number that tracks the Approval Signature

ADOITIONAL 
HNF-1901

Revision 2

\section{Technical Baseline}

Summary Description for the Tank Farm Contractor

Prepared for the U.S. Department of Energy

Assistant Secretary for Environmental Management

\section{CH2MHILL \\ Hanford Group, Inc.}

Richland, Washington

Contractor for the U.S. Department of Energy

Office of River Protection under Contract DE-AC06-99RL14047

Approved for Public Release; Further Dissemination Unlimited 
THIS PAGE INTENTIONALLY

LEFT BLANK 
HNF-1901

Revision 2

\section{Technical Baseline \\ Summary Description for the Tank Farm Contractor}

Prepared for the U.S. Department of Energy

Assistant Secretary for Environmental Management

\section{CH2MHILL \\ Hanford Group, Inc.}

Richland, Washington

Contractor for the U.S. Department of Energy

Office of River Protection under Contract DE-ACO6-99RL14047

Approved for Public Release; Further Dissemination Unlimited 
LEGAL DISCLAIMER

This report was prepared as an account of work sponsored by an agency of the United States Government. Neither the United States Government nor any agency thereof, nor any of their employees, nor any of their contractors, subcontractors or their employees, makes any warranty, express or implied, or assumes any legal liability or responsibility for the accuracy, completeness, or any third party's use or the results of such use of any information, apparatus, product, or process disclosed, or represents that its use would not infringe privately owned rights. Reference herein to any specific commercial product, process, or service by trade name, trademark, manufacturer, or otherwise, does not necessarily constitute or imply its endorsement. recommendation, or favoring by the United States

Government or any agency thereof or its contractors or subcontractors. The views and opinions of authors expressed herein do not necessarily state or reflect those of the United States Government or any agency thereof.

This report has been reproduced from the best available copy.

Available in paper copy and microfiche.

Available electronically at

http://www.doe.gov/bridge. Available for a processing fee to the U.S. Department of Energy and its contractors, in paper, from:

U.S. Department of Energy

Office of Scientific and Technical Information

P.O. Box 62

Oak Ridge, TN 37831-0062

phone: 865-576-8401

fax: 865-576-5728

omail: reports@adonis.osti.gov(423) 576-8401

Available for sale to the public, in paper, from:

U.S. Department of Commerce

National Technical Information Service

5285 Port Royal Road

Springfield, VA 22161

Phone: 800-553-6847

fax: 703-605-6900

email: orders@ ntis.fedworld.gov

online ordering:

http://www.ntis.gov/ordering.htm 


\title{
Technical Baseline Summary Description for the Tank Farm Contractor
}

\author{
A. R. Tedeschi \\ CH2M HILL Hanford Group, Inc. \\ Richland, WA 99352 \\ U.S. Department of Energy Contract DE-AC06-99RL14047
EDT/ECN: $660089 \quad$ UC: 2030
Cost Center: 71300
B\&R Code: EW310010
Charge Code: $108521 / \mathrm{AA} 3$
Total Pages: 193 \\ Key Words: technical baseline, tank farm, design, requirement
}

\begin{abstract}
:
This document is a revision of the document titled above, summarizing the technical baseline of the Tank Farm Contractor. It is one of several documents prepared by CH2M HILL Hanford Group, Inc. to support the U.S. Department of Energy Office of' River Protection Tank Waste Retrieval and Disposal Mission at Hanford.
\end{abstract}

TRADEMARK DISCLAIMER. Reference herein to any specific commercial product, process, or service by trade name, trademark, manufacturer, or otherwise, does not necessarily constitūte or imply its endorsement, recommendation, or favoring by the United States Government or any agency thereof or its contractors or subcontractors.

Printed in the United States of America. To obtain copies of this document, contact: Document Control Services, P.O. Box 950, Mailstop H6-08, Richland WA 99352, Phone (509) 372-2420; Fax (509) 376-4989.

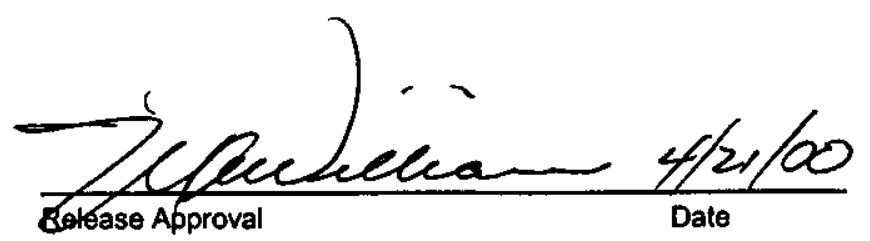

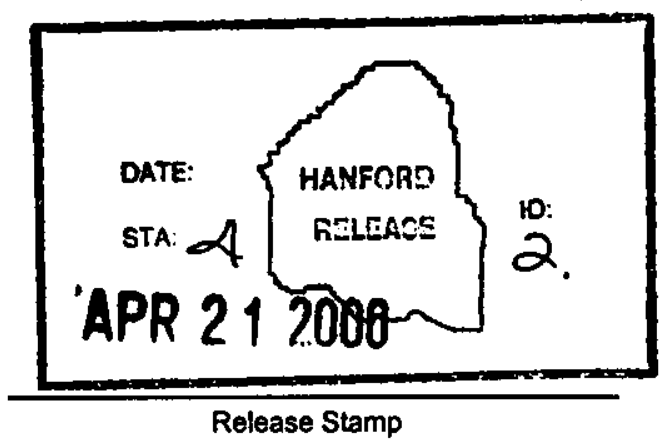

Release Stamp 
RECORD OF REVISION

(1) Document Number

HINF-1901, ReV. 2

Page 1

(2) Tite

Technical Baseline Summary Description for the Tank Farm Contractor

Change Control Record

(3) Revision

1

$2 \cdot R S$
(4) Description of Change - Replace, Add, and Delete Pages

(7)

ECN \#656080, periodic update/revision 12/29/99

ECN \#660089, periodic update/revision 4/21/00
Authorized for Release

\begin{tabular}{l|l} 
(5) Cog. Engr. & (6) Cog. Mgr. Date
\end{tabular}

OR Dovalle AH Friberg AR Tedegghi 


\title{
Technical Baseline Summary Description for the Tank Farm Contractor
}

Prepared by:

\author{
A. R. Tedeschi \\ CH2M HILL Hanford Group, Incorporated
}

Date Published

April 2000

Prepared for the U.S. Department of Energy

Assistant Secretary for Environmental Management

\section{CH2MHILL \\ Hanford Group, Inc.}

P. O. Box 1500

Richland, Washington

Contractor for the U.S. Department of Energy

Office of River Protection under Contract DE-ACO6-99RL14047 
HNF-1901 REV 2

This page intentionally left blank. 


\section{HNF-1901 REV 2}

Document Title: Technical Baseline Summary Description for the Tank Farm Contractor

Approved by:

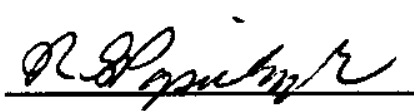

R. S. Popielarczyk, Chief Engineer
$4 / 21 / 00$

Date 


\section{HNF-1901 REV 2}

This page intentionally left blank. 


\section{EXECUTIVE SUMMARY}

This document, the Technical Baseline Summary Description for the Tank Farm Contractor, is one of several documents prepared by CH2M HILL Hanford Group, Inc., to support the U.S. Department of Energy Office of River Protection's mission at the Hanford Site to protect the Columbia River. This mission includes the programs necessary to support tank waste storage and retrieval, waste feed delivery, storage of immobilized waste, and closure of tank farms. Completion of this mission enables the tank farms to be closed and turned over for final remediation.

The purpose of this document is to summarize the technical baseline of the Tank Farm Contractor. The technical baseline is the set of equipment, facilities, materials, staff qualifications, and enabling documentation needed to start up and complete mission objectives. The value of identifying a technical baseline is to ensure adequate implementation of mission requirements through the entire project life cycle and cost-effective management of technical information.

The earlier version of this document, HNF-1901 Rev. 1, focused primarily on technical information generated in support of the Waste Immobilization Phase 1 of the Level 0 River Protection Project Mission Logic (Drawing TWR-2086), specifically, the technical baseline directly supporting the Tank Waste Retrieval and Disposal mission. This document continues that focus and has been updated to the latest technical baseline definition.

This document revision supersedes the Tank Waste Remediation System Technical Baseline Summary Description, HNF-2016, Revision 0 (Raymond 1998), prepared for summarizing the technical baseline of the Tank Farm Contractor for mission activities other than tank waste retrieval and disposal. This document thus contains the summary of technical baseline information for all activities of the Tank Farm Contractor. 


\section{HNF-1901 REV 2}

This page intentionally left blank.

ES-2 


\section{CONTENTS}

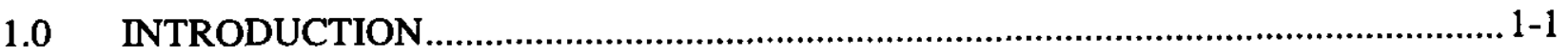

1.1 DOCUMENT CHANGES ……...................................................................1-1

1.2 TECHNICAL BASELINE DEFINITIONS ......................................................1-2

1.2.1 Technical Baseline ........................................................................ 1-2

1.3 TECHNICAL BASELINE GENERATION …….............................................1-3

1.4 STRUCTURE OF DOCUMENT ...................................................................... 1-5

1.5 INTEGRATED SAFETY MANAGEMENT SYSTEM APPLICATION............1-6

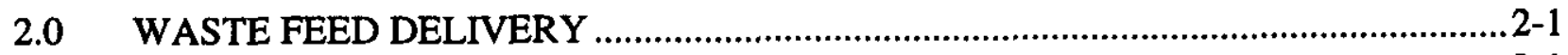

$2.1 \quad$ PRIMARY WASTE DEFINITION ……….................................................... $2-1$

$2.2 \quad$ PROCESS DEFINITION .............................................................................. $2-1$

2.3 STRUCTURES, SYSTEMS, AND COMPONENTS ………….........................2-2

2.3.1 System and Project Definition...................................................................2-2

2.3.2 Reliability, Availability, and Maintainability Risk Evaluation.................2-3

2.4 OPERATIONS, MAINTENANCE, AND SUPPORTING DOCUMENTS .......2-3

2.4.1 Operations and Maintenance Concept.........................................................2-3

2.4.2 Permits and Safety Authorizations.......................................................2-3

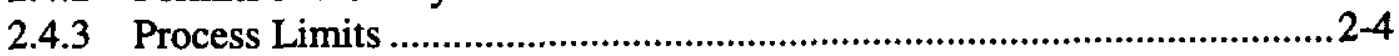

2.4.4 Safety Equipment List ...........................................................................2-4

2.4.5 Operations and Maintenance Procedures ....................................................2-4

2.4.6 Operations and Maintenance Records ....................................................2-4

2.4.7 Staff Qualifications ............................................................................. 2-5

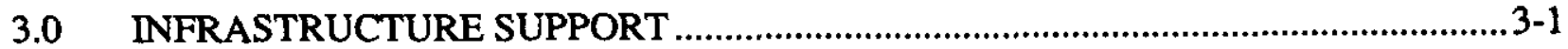

3.1 PRIMARY WASTE AND PRODUCT DEFINITIONS ....................................... 3-1

3.2 PROCESS DEFINITION ................................................................................. 3-1

3.3 STRUCTURES, SYSTEMS AND COMPONENTS ……..................................... 3-1

3.3.1 Systems and Project Definition ...................................................................3-2

3.4 OPERATIONS, MAINTENANCE, AND SUPPORTING DOCUMENTS ........3-2

3.4.1 Operations and Maintenance Concept....................................................... 3-2

3.4.2 Permits and Safety Authorizations ........................................................... 3-2

3.4.3 Process Limits .......................................................................................... 3-3

3.4.4 Operations and Maintenance Procedures .................................................... 3-3

3.4.5 Operations and Maintenance Records ........................................................ 3-3

4.0 PRIVATIZATION CONTRACTOR INTERFACE ...................................................... 4-1

5.0 PRODUCT STORAGE AND DISPOSAL ……............................................................. 5-1

5.1 PROCESS DEFINITION ............................................................................ 5-1

5.1.1 Immobilized Low-Activity Waste.............................................................5-1

5.1.2 Immobilized High-Level Waste ............................................................5-2

5.2 STRUCTURES, SYSTEMS, AND COMPONENTS ……................................5-2

5.2.1 Reliability, Availability, and Maintainability Risk Evaluation..................5-2 
5.3 OPERATIONS, MAINTENANCE, AND SUPPORTING DOCUMENTS .......5-2

5.3.1 Operations and Maintenance Concept.....................................................5-3

5.3.2 Permits and Safety Authorizations...........................................................5-3

5.3.3 Process Limits ........................................................................................5-3

5.3.4 Operations and Maintenance Procedures ………..........................................5-3

5.3.5 Operations and Maintenance Records ......................................................5-4

5.4 SECONDARY WASTE DEFINITION ............................................................. 5-4

6.0 UTILITY SERVICES INTERFACE

7.0 CLOSURE

7.1 PRIVATIZATION CONTRACTOR FACILITIES ................................................ 7-1

7.2 IMMOBILIZED WASTE FACILITIES .............................................................. 7-1

7.2.1 Immobilized Low-Activity Waste Facilities ................................................ 7-1

7.2.2 Immobilized High-Level Waste Facilities ................................................. 7-2

7.3 TANK FARM SYSTEMS ……………….................................................. 7-2

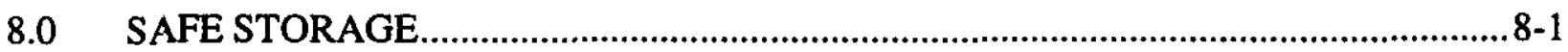

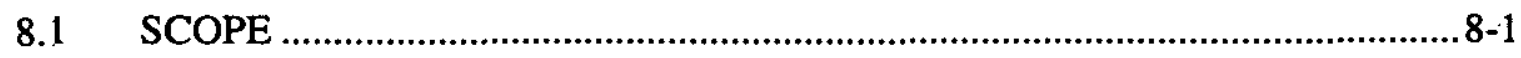

8.2 REQUIREMENTS BASELINE

8.2.1 Permits and Licenses................................................................... 8-1

8.2.2 Requirements Databases .................................................................. 8-1

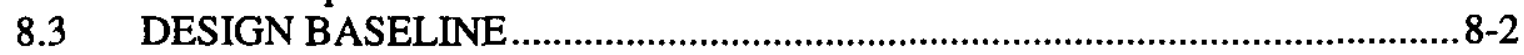

8.3.1 System Design Descriptions..........................................................................8-2

8.3.2 Drawing and Drawing Change Documents..................................................8-2

8.3.3 Specifications .......................................................................................... 8-2

8.3.4 Design Review Packages .................................................................... 8-2

8.3.5 Acceptance Tests................................................................................... 8-2

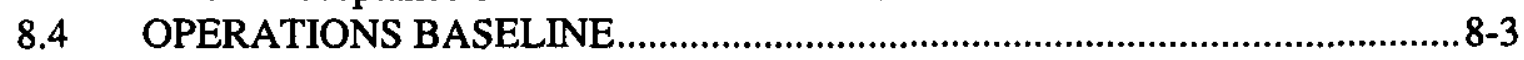

8.4.1 Staff Qualifications ............................................................................. 8-3

8.4.2 Authorization Basis Documents................................................................. 8-3

8.4.3 Operating Procedures, Surveillance Sheets, and Maintenance

8.4.4 Process Tests and Control Documents ....................................................8-3

8.4.5 Operational Databases................................................................................8 8-3

8.4.6 Safety Equipment List ......................................................................... 8-4

8.4.7 Spare Parts Documentation ...................................................................... 8-4

8.4.8 Operational Specification Document ......................................................8-4 
HNF-1901 REV 2

\section{APPENDICES}

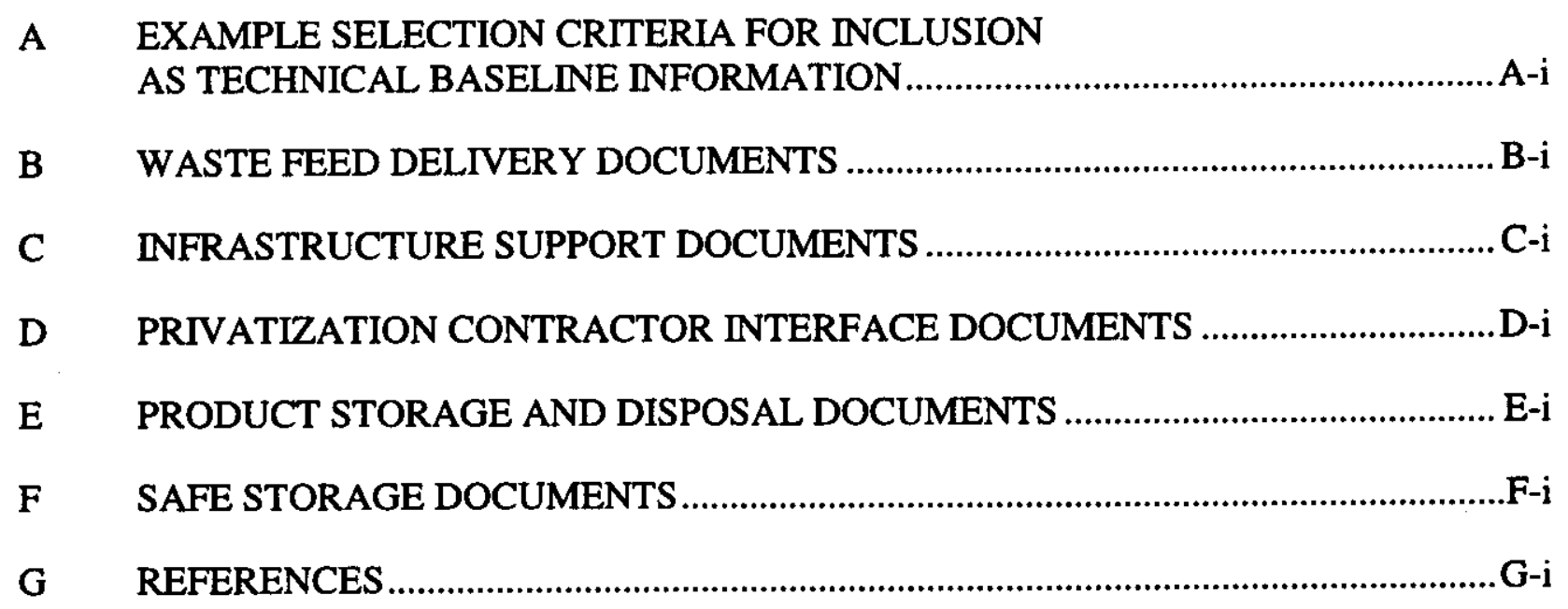

\section{FIGURES}

Figure 1-1. Technical Baseline Document Hierarchy and Process.........................................1-4

Figure 1-2. Technical Baseline Document Structure. .......................................................... 1-5

\section{TABLES}

Table 4-1. Interface Control Document Category Placement. 


\section{TERMS}

BNFL

CSB

DOE

DST

DYN

ES\&H

FH

HLW

ICD

IHLW

ILAW

LAW

ORP

RAM

RPP

SEMP

SSC

TSR

TWR\&D
BNFL Inc.

Canister Storage Building

U.S. Department of Energy

double-shell tank

DynCorp Tri-Cities Services, Inc.

environmental, safety, and health

Fluor Hanford, Inc.

high-level waste

interface control document

immobilized high-level waste

immobilized low-activity waste

low-activity waste

Office of River Protection

reliability, availability, and maintainability

River Protection Project

Systems Engineering Management Plan for the Tank Farm

Contractor

structures, systems, and components

technical safety requirement

Tank Waste Retrieval and Disposal (organization) 


\subsection{INTRODUCTION}

This document provides a summary description of the technical baseline for the Tank Farm Contractor. The Tank Farm Contractor provides mission support to the U.S. Department of Energy (DOE) Office of River Protection's (ORP) effort to ensure protection of the Columbia River. The ORP manages specifically the River Protection Project (RPP) mission to store, retrieve, treat, and dispose of Hanford's tank waste. The Tank Farm Contractor's mission includes the programs necessary to support RPP tank waste storage and retrieval, waste feed delivery to the Privatization Contractor, storage of immobilized waste produced by the Privatization Contractor, and tank farm closure. The full range of RPP missions and objectives is discussed in more detail in DOE/ORP-2000-10, River Protection Project Mission Analysis Report (ORP 2000a).

The technical baseline definition is first defined in DOE/ORP-2000-06 River Protection Project - Project Management Plan (ORP 2000b) which flows down contractually into baseline management documents. This technical baseline development process is outlined in both the RPP-6017 Draft Project Execution Plan for the Tank Farm Contractor (Halverson 2000), and the HNF-SD-WM-SEMP-002, Systems Engineering Management Plan for the Tank Farm Contractor (SEMP) (O'Toole 2000). The SEMP describes the tenets for the technical baseline strategy, developed from contractual requirements and constraints. These tenets include a focus on RPP Privatization Phase 1 activities. The balance of mission development, through a top-down system engineering process, is described in summary.

Identification of technical information as "technical baseline" performs the following functions:

- Identifies the minimal set of data necessary to be controlled under configuration management processes (e.g., maintaining accuracy and ensuring linkage with other affected technical information) out of the entire data set

- Provides an efficient methodology to verify adequate interfaces where many contractual and projectized activities exist.

\subsection{DOCUMENT CHANGES}

This document was originally issued as the Tank Waste Remediation System Retrieval and Disposal Mission Technical Baseline Summary Description (HNF-1901, Rev. 0, January 6, 1998). A subsequent revision in December 29, 1999, renamed the document to RPP Tank Waste Retrieval and Disposal Mission Technical Baseline Summary Description. Rev. 1 was an annual revision that added/revised technical baseline documents. This current document is the next step in improved technical baseline management for the Tank Farm Contractor.

New and revised technical information supporting the tank waste retrieval and disposal mission was added to this document. Additions and deletions to technical information also were made to support revised baseline definitions and hierarchy. New information was also added to begin populating the detailed listing of the technical baseline in the appendices with documents from the tank waste storage mission. One example of new technical information is the Tank Farm 
Essential Drawing Plan (Domnoske-Rauch 2000), which includes listings of essential drawings necessary for normal tank farm operation.

The Tank Farm Contractor, the Privatization Contractor, and the Project Hanford team have specific roles in executing the mission of the ORP. Each contractor develops technical baseline information. Technical baseline information managed by other Project Hanford contractors was included in prior versions of this document. This was done prior to establishment of the ORP, and subsequent contract changes providing direct reporting of the Tank Farm Contractor to ORP. Some of this information was removed when not relevant to the Tank Farm Contractor. The material left in was maintained to provide interface information. Higher level bases documents were removed from the technical baseline listing but are still referenced as contractually required documents.

A significant portion of text was removed in this version to eliminate redundant scope and mission activities better described in other Tank Farm Contractor documents. Section verbiage also was reduced to eliminate redundant document information contained in the appendices.

Pertinent information from HNF-2016, Tank Waste Remediation System Technical Baseline Summary Description (Raymond 1998) was added to this document to include a summary of the technical baseline for the balance of mission and begin population of technical information in the appendices. This document supersedes HNF-2016, establishing a single summary source for the technical baseline of the Tank Farm Contractor. This document will be revised periodically to include new or revised technical information for Tank Farm Contractor mission activities.

\subsection{TECHNICAL BASELINE DEFINITIONS}

The "technical baseline" as used herein is defined in DOE/ORP-2000-06, River Protection Project - Project Management Plan (ORP 2000b). Subset definitions of requirements, design, and operations baselines were revised through an engineering task team to be consistent with DOE Orders and Good Practice Guides: Life Cycle Asset Management (DOE OH430.1A), Project Execution and Engineering Management and Planning (GPG-FM-010), Configuration and Data Management (GPG-FM-012), and Baseline Development (GPG-FM-016) and HNF1900, Configuration Management Plan for the Tank Farm Contractor (Weir 2000). The applicable technical baseline subset definition was added to each document listed in Appendix B through $\mathrm{F}$. These subset definitions assist identification of the technical baseline in all phases of the project life cycle. They also assist identification of owners and subsequent configuration management of the technical information.

\subsubsection{Technical Baseline}

The technical baseline is the set of equipment, facilities, materials, staff qualifications, and enabling documentation needed to start up and complete mission objectives. The technical baseline consists of the following parts: requirements baseline, design baseline, and operations baseline. 


\subsubsection{Requirements Baseline}

The requirements baseline is the technical information that defines the customer's expectations, constraints, required products, and mission boundaries. The requirements baseline includes contractual requirements as well as contractor-generated or derived requirements. Examples include interface control documents (ICD), project flow sheets, and project definition criteria.

\subsubsection{Design Baseline}

The design baseline is the technical information that defines the processes and structures, systems, and components (SSC) necessary for the safe operation and delivery of products. Examples include drawings, procurement specifications, and test procedures.

\subsubsection{Operations Baseline}

The operations baseline is the technical information that defines the conduct of operation and maintenance of the SSCs. Examples include authorization bases, permits, operating procedures, and maintenance manuals.

\subsection{TECHNICAL BASELINE GENERATION}

The technical baseline is generated using the iterative systems engineering process. Technical information is identified for inclusion within the technical baseline set by evaluation of products, processes, and SSCs beginning with schedules, requirements, and other data. The original hierarchy encompassing the system engineering process and products was contained in the Hanford Site Technical Baseline Database. This flow-down for technical baseline identification is described by a document hierarchy in RPP-6017, Draft Project Execution Plan for the Tank Farm Contractor (Halverson 2000). The document hierarchy is depicted in Figure 1-1.

Selection of the technical baseline proceeds by applying the baseline definitions to missionrelated products, processes, and SSCs. Mission documents and technical expertise are used to apply these filters and to establish the technical baseline information set. Bases documents, such as DOE/ORP 2000-10 (ORP 2000) are used as tools to identify products, processes, and SSCs. Mission documents also define currently planned major projects. Technical information representing the products, processes, and SSCs of these projects are considered in the technical information set. A list of queries that help identify products, processes, and SSCs is included in Appendix A. Although the queries are not exhaustive, they assist the technical data owners in identifying technical information belonging to the technical baseline data set.

The identification of technical baseline information from vertical hierarchical requirements and mission scope is supplemented by evaluation of the lateral life cycle of the facilities, materials, and SSCs. This lateral view is depicted in Figure 1-2 (Halverson 2000). This figure shows the usage of technical baseline information through a life cycle. It also shows an identification of technical information by technical baseline subsets (requirements, design, operations). This lateral life cycle structure assists in initial identification and configuration management of the technical baseline information. 


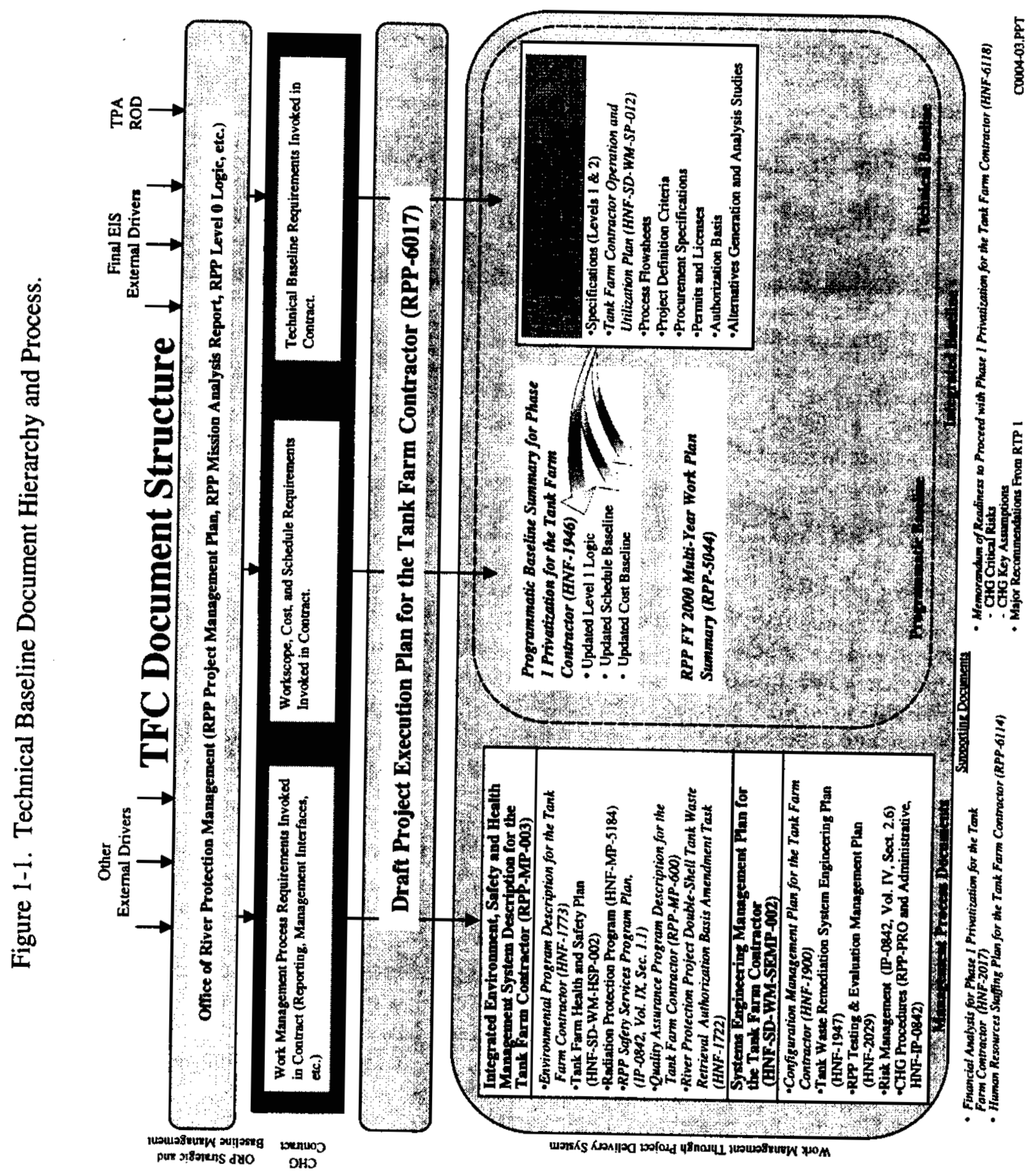


The technical baseline will grow in the succeeding years in accordance with scope, schedule, and budget. As schedule logic (e.g., River Protection Project Level-0 Logic (Drawing No. TWR-2086) changes, technical baseline information will change. Modifications to upper requirements and data also will drive changes in the technical baseline information set.

The process for developing and maintaining the Tank Farm Contractor technical baseline documents is described in more detail in HNF-1947, Tank Waste Remediation System Engineering Plan (Rifaey 1998). The technical baseline information within this document, and in a future database/information management system, is maintained under configuration management control to ensure quality baseline information set. Configuration control processes are described in HNF-1947 (Rifaey 1998) and HNF-1900 (Weir 2000).

Maintaining this summary description document includes the following:

- Reviewing new and revised technical baseline documents

- Assigning document categories (e.g., configuration information, requirement, source document) and identifying the source information for each document.

\begin{tabular}{|c|c|c|c|c|c|c|}
\hline \multirow{2}{*}{ 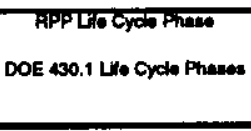 } & \multirow{2}{*}{$\begin{array}{l}\text { poriominos Noded of } \\
\text { Contraints } \\
\text { Planning }\end{array}$} & \multirow{2}{*}{ 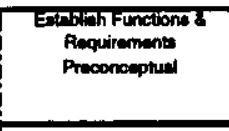 } & 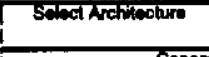 & bowon & xopoin & openio \\
\hline & & & \multicolumn{2}{|c|}{$\begin{array}{l}\text { Conowphat Phuse } \\
\text { Desipn Phese }\end{array}$} & $\begin{array}{l}\text { Costruction Pheas } \\
\text { Turnower Phese }\end{array}$ & 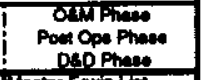 \\
\hline Operotions into & 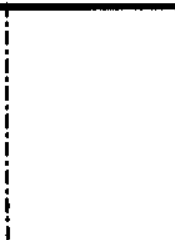 & & & 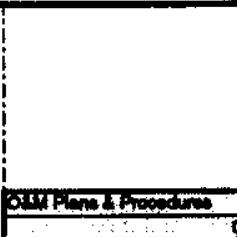 & 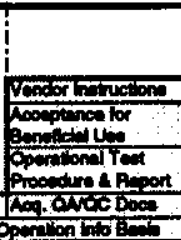 & 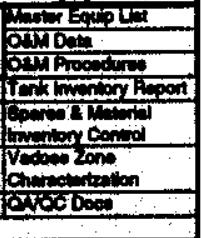 \\
\hline Decten info & ! & & & 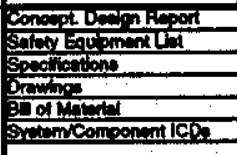 & 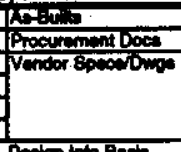 & \\
\hline 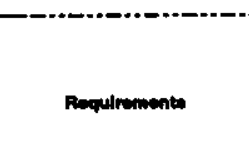 & 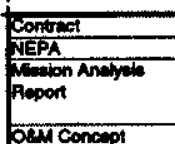 & 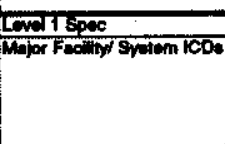 & 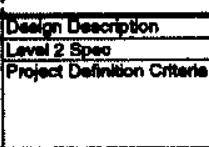 & 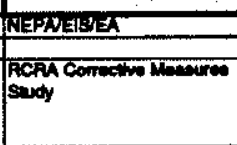 & 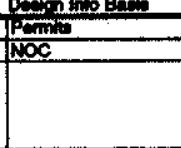 & 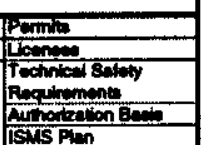 \\
\hline & & & Extin & $\frac{B \text { Bais }}{\text { treints }}$ & & \\
\hline
\end{tabular}

Figure 1-2. Technical Baseline Document Structure.

\subsection{STRUCTURE OF DOCUMENT}

The remaining sections 2.0 through 8.0 of this document briefly summarize the general scope of the technical baseline information included in the appendices.

The contents of each of the document sections are as follows.

- Section 2.0 addresses work and technical documents related to processing and retrieval of waste from the tanks and delivery of the waste feed to the Privatization Contractor. 
- Section 3.0 addresses work and technical documents related to providing infrastructure equipment and services for waste feed delivery.

- Section 4.0 addresses work and ICDs related to the Privatization Contractor's work to treat and immobilize the tank waste.

- Section 5.0 addresses work and technical documents related to receipt and disposal of immobilized low-activity waste (ILAW) and immobilized high-level waste (IHLW) and other products from the Privatization Contractor.

- Section 6.0 addresses work and technical documents related to utility services.

- Section 7.0 addresses work and technical documents related to tank and facility closure.

- Section 8.0 addresses work and technical documents related to tank waste storage.

This document contains seven appendices ( $A$ through $G$ ). Appendix $A$ is a listing of example selection criteria for technical baseline information inclusion. Appendices B through $\mathrm{F}$ support the scope sections described in sections 2.0 through 5.0, and section 8.0. Appendix $G$ provides document references. The reference citations are presented in tables according to categories (e.g., tank characterization reports, double-shell tank [DST] waste retrieval specifications, and other documents) listed on the first page of the appendix.

\subsection{INTEGRATED SAFETY MANAGEMENT SYSTEM APPLICATION}

RPP-MP-003, Integrated Environment, Safety, and Health Management System Description for the Tank Farm Contractor (CHG 2000a), establishes the systematic approach used by ORP and the contractor to integrate safety into management and work practices at all levels. Total safety integration enables the assigned missions to be efficiently and effectively accomplished while protecting the public, the worker, and the environment. This is to be accomplished through effective integration of safety management into all facets of work planning and execution. The technical baseline represents the implementation results of several facets of the integrated safety management process. It documents defined workscope, identified hazards, and hazard control processes. 
HNF-1901 REV 2

\subsection{WASTE FEED DELIVERY}

This section summarizes waste feed delivery bases and technical baseline documentation. Specific technical baseline document information related to this section is located in Appendix B.

\subsection{PRIMARY WASTE DEFINITION}

Tank waste consists of byproducts from chemical separations processing of irradiated nuclear fuel. The waste is highly radioactive because it contains fission and activation products from the fuel as well as smaller amounts of uranium and other actinides. The waste also contains residuals of the chemicals used in various separations processes performed at the Hanford Site. Other chemical additions were made to the waste to minimize corrosion of the underground storage tanks. Although similarities exist between the waste in the tanks, each tank contains waste with a unique composition.

A "best-basis" inventory was developed on a total-tank basis and for each of the 177 underground storage tanks. The best-basis inventory is located in HNF-SD-WM-TI-740, Standard Inventories of Chemicals and Radionuclides in Hanford Site Tank Wastes (Kupfer et al. 1997), and in 177 individual tank characterization reports (see Appendix B and Appendix G). These documents report work performed to date to establish standard total-tank and tank-by-tank component inventory estimates. The Tank Farm Contractor Characterization Program establishes an annual plan for tank waste sampling activities. The plan is outlined in HNF-SD-WM-PLN-126, Fiscal Year 1997 - 1998 Waste Information Requirements Document (Winkelman et al. 1997). The Tank Waste Retrieval and Disposal (TWR\&D) organization is developing data quality objectives, which are used to define further tank waste characterization efforts.

\subsection{PROCESS DEFINITION}

The privatization contract (ORP 1998) between DOE and the Privatization Contractor, BNFL Inc. (BNFL), is a source document for defining end-point requirements for the Waste Feed Delivery System. Under the DOE strategy, privatization takes place in two phases. In Privatization Phase 1 (demonstration phase) tank waste is retrieved and delivered to the Privatization Contractor by the RPP. The waste feed delivery process separates tank waste into a low-activity waste (LAW) fraction and a high-activity waste (HLW) fraction. Specifications in the privatization contract were used to define planning assumptions for the Waste Feed Delivery Program and other programs supporting the TWR\&D mission.

The operating scenario and the sequence of waste retrieval and delivery to the Privatization Contractor is defined in HNF-SD-WM-SP-012, Tank Farm Contractor Operation and Utilization Plan (Kirkbride 2000). The source of the process to be used for satisfying the envelope and delivery quantity requirements, along with laboratory testing and modeling that serve to establish the basis of the unit processes also are presented in HNF-SD-WM-SP-012 (Kirkbride 2000). The detailed flowsheets for these processes are defined in a set of waste feed 
delivery technical-basis flowsheets (HNF-1939, Waste Feed Delivery Technical Summary Baseline, Volume II, Addendum 1-1, "Waste Feed Delivery Flowsheet for 241-AZ-101" [Orme 1999a];Volume II, Addendum 2-1, "Waste Feed Delivery Flowsheet for 241-AN-105" [Orme 1999b]; Volume II, Addendum 3-1, "Waste Feed Delivery Flowsheet for 241-AN-104" [Orme 1999c]). To date, flowsheets have been developed specifically for delivery of waste from Tanks 241-AN-104, 241-AN-105, and 241-AZ-101 to the Privatization Contractor. The flowsheets contain both mass and energy balances.

\subsection{STRUCTURES, SYSTEMS, AND COMPONENTS}

SSCs for waste feed delivery are defined as the hardware and software required to process and transfer feed to the Privatization Contractor. Existing and future equipment used to transfer feed to the Privatization Contractor are identified as part of a waste feed delivery technical basis system description (HNF-1939, Waste Feed Delivery Technical Basis, Volume III, "Waste Feed Delivery System Description" [Rasmussen 1999]). This document identifies the specific tanks, associated piping and piping components, instrumentation and control systems, and ancillary equipment required to prepare and transfer the waste.

\subsubsection{System and Project Definition}

The Waste Feed Delivery System includes existing equipment as well as equipment to be provided by several projects. A number of the projects identified below predate the current TWR\&D mission. The objectives of each of these projects, however, are consistent with needs of the mission and the Waste Feed Delivery Program. The functional and technical requirements and products of each of these projects have been (or are being) evaluated and adjusted to support the current mission.

Top-level equipment and functional requirements for the overall DST system are defined in HNF-SD-WM-TRD-007, System Specification for the Double-Shell Tank System (CHG 2000). Specific hardware system functional criteria are further described in Level II specifications. After the functions and requirements and component specification documents are completed, the functional design criteria for the Waste Feed Delivery System projects will be reviewed and revised as needed to ensure compliance.

The following projects provide equipment necessary to satisfy the Privatization Phase 1 requirements of the Waste Feed Delivery System.

- Project W-314: Tank Farm Restoration and Safe Operations, provides new transfer piping, valving, and master-pump shutdown equipment.

- Project W-211: Initial Tank Retrieval System, provides new pumps (mixer pumps, decant pumps, slurry pumps, and supernate pumps); electrical system upgrades; instrumentation and control system upgrades; chemical addition system; and valving upgrades. 
- Project W-521: Waste Feed Delivery Systems, provides retrieval, transfer, and feed delivery systems to tie tank farms to the vitrification processing facility.

- Project W-151: AZ-101 Mixer Pumps, provides two mixer pumps, instrumentation and control upgrades, and electrical system upgrades in Tank 241-AZ-101.

Additional projects will be added to this document as their definition matures.

\subsubsection{Reliability, Availability, and Maintainability Risk Evaluation}

A waste feed delivery reliability, availability, and maintainability (RAM) risk evaluation was documented for an HLW feed tank (241-AZ-101) and LAW feed tanks (241-AN-104 and 241-AN-105) in HNF-2863, Waste Feed Delivery System Phase 1 Baseline RAM Assessment July 1998, (Dykes et al. 1998). This RAM analysis is updated for each tank and associated transfer system. The first RAM/risk evaluation was produced during fiscal year 1998. This RAM/risk evaluation is used to confirm or revise each tank's operating and maintenance concept and may be used as a basis for revising design requirements and for developing the spare equipment list for the Waste Feed Delivery System.

\subsection{OPERATIONS, MAINTENANCE, AND SUPPORTING DOCUMENTS}

Operations, maintenance, and supporting technical baseline documents are those documents that are used to enable and control field activities. Related documents are described in the following subsections.

\subsubsection{Operations and Maintenance Concept}

A waste feed delivery technical-basis operations and maintenance concept technical baseline document was generated in concert with the waste feed delivery RAM/risk evaluation, process flowsheets (Orme 1999a, 1999b, and 1999c), and system description (Rasmussen 1999). The operations and maintenance document is being used for developing waste feed delivery operation plans, maintenance plans, and operating and maintenance procedures. The operations and maintenance concept for the Waste Feed Delivery System is derived from current operating and maintenance practices and from new specification documents including HNF-SD-WM-TRD-007 (CHG 2000), which establishes functional and performance requirements for DST equipment systems.

\subsubsection{Permits and Safety Authorizations}

Permitting activities related to the RPP are identified in HNF-1773, Environment Program Description for the Tank Farm Contractor (Powell 2000), which addresses environmental policy requirements; permit and compliance responsibilities; planning; reports, notifications, and 
records; verification corrective actions; and preliminary permit modification schedules. The range of environmental actions, including required permits and other agency approvals that may affect waste feed delivery activities in the RPP, are described in HNF-2401, Waste Feed Delivery Environmental Permits and Approvals Plan (Tollefson and Potter 2000). The current list of environmental permits and related documentation can be found in HNF-4474, RPP Environmental Permits and Related Documentation (Dexter 1999). The safety Authorization Basis under which the Tank Farm Contractor currently operates is found in HNF-SD-WM-SAR-067, Tank Waste Remediation System Final Safety Analysis Report (CHG 2000c). That document is being amended to allow for Privatization Phase 1 operations and related field activities according to HNF-1722, River Protection Project Double-Shell Tank Waste Retrieval Authorization Basis Amendment Task Plan (Harris 2000).

\subsubsection{Process Limits}

Waste feed delivery process limits include operating limits and technical safety requirements (TSR). Operating limits are imposed to ensure that processing is at an acceptably low risk of failure to deliver on-specification waste to the Privatization Contractor on time. The TSRs are used to ensure the safe operation of tank farm facilities. The current TSRs for the Tank Farm Contractor are identified in HNF-SD-WM-TSR-006, Tank Waste Remediation System Technical Safety Requirements (CHG 2000a). That document defines acceptable conditions, safe boundaries, and bases thereof. Management or administrative controls required to ensure safe operation also are defined.

\subsubsection{Safety Equipment List}

HNF-SD-WM-SEL-040, TWRS Facility Safety Equipment List (Zaman 1999), lists the safety SSCs credited with preventing or mitigating hazards identified in safety basis documents. This document also defines the components of safety SSCs described only at the system level in the safety basis.

\subsubsection{Operations and Maintenance Procedures}

Operations and maintenance procedures are being developed for the Waste Feed Delivery System. Procedures are developed after the project designs are completed.

\subsubsection{Operations and Maintenance Records}

Operations and maintenance records include calibration, process performance, and system surveillance documents. As the Waste Feed Delivery System is defined, operations and maintenance procedures are written to govern recordkeeping activities. 


\subsubsection{Staff Qualifications}

Staff qualification is performed through establishment of minimum proficiency requirements and additional training. This program and specific certification/qualification training requirements are identified in procedures in HNF-IP-0842, RPP Administration, Volume III, "Training" (CHG 2000b). Additional training establishes generic training requirements and job specific certifications or qualifications. Generic training assures a minimum proficiency with site safety, quality, environment, security, and company requirements. Job specific training assures proficiency with specific SSC, procedure, discipline, and organizational requirements.

Completed generic and specific training records are maintained in training files. Examples of specific certifications and qualifications completed by Tank Farm Contractor personnel are: design authority, process engineer, radiological design, RPP facility criticality safety engineer, tank farm field crew, tank farm routines, tank farm retrieval, characterization core sampling rotary mode, senior shift technical advisor, tank farm operations engineer, and project manager. 
HNF-1901 REV 2

This page intentionally left blank. 


\subsection{INFRASTRUCTURE SUPPORT}

This section summarizes infrastructure support bases and technical baseline documentation. The Infrastructure support services that BNFL requires during completion of the Privatization Phase 1B mission are defined in documents in Appendix C.

The Infrastructure Program is responsible for ensuring that infrastructure services are provided to the Privatization Contractor, BNFL, during construction, startup, and production of its waste treatment facility in support of the Privatization Phase 1B of the TWR\&D mission.

Project W-519 provides access roads, land for siting the BNFL waste treatment facility and support equipment, raw and potable water, electricity, and transfer pipelines for liquid effluents. On completion of Project W-519, the Infrastructure Program, DynCorp Tri-Cities Services (DYN), and Fluor Hanford, Inc. (FH) will ensure that infrastructure services (i.e., roads, raw and potable water, electricity), radioactive-solid-waste disposal, and liquid-effluent transfers (i.e., nonradioactive/nondangerous and radioactive/dangerous) continue to support BNFL through the duration of the Phase 1B mission.

\subsection{PRIMARY WASTE AND PRODUCT DEFINITIONS}

The ORP/RPP team and BNFL ICDs and the privatization contract (ORP 1998) serve as the basis for defining the waste products expected from BNFL.

\subsection{PROCESS DEFINITION}

During Privatization Phase 1B, BNFL constructs, starts up, and commences operation of its waste treatment facility. Project W-519 was formed to perform infrastructure construction activities (e.g., access road development, water pipelines upgrades) to accommodate Phase 1B infrastructure needs for BNFL. After the completion of Project W-519 construction activities, the Infrastructure Program ensures that infrastructure needs for BNFL are met during the Phase 1B mission.

\subsection{STRUCTURES, SYSTEMS AND COMPONENTS}

The SSCs currently in place are documented in agreements in principle (LMHC 1999a, 1999b), the Project W-519 design drawings and specifications, and other project-specific documents. Hanford Site as-built drawings affected by Project W-519 and BNFL construction activities are being updated to reflect physical interfaces and equipment configuration changes. All documents related to SSCs are reviewed periodically against the ICDs. Significant changes are incorporated into the technical baseline after they are validated. In addition, the Tank Farm Contractor is responsible for the design and construction of a waste transfer pipeline from the Tank Farm Contractor LAW/HLW staging tanks to the BNFL LAW/HLW staging tanks. BNFL provides and installs the necessary tank, ancillary equipment, monitoring hardware 
(e.g., ventilation, emissions), and control systems to receive and transfer waste from the BNFL staging tanks to its facilities. The design of the LAW/HLW transfer pipeline, as well as the location of the LAW staging $\operatorname{tank}(\mathrm{s})$, is being developed.

\subsubsection{Systems and Project Definition}

The Infrastructure Program provides utility and electrical support to BNFL through existing or new infrastructure systems. Upgrade of the existing Hanford Site infrastructure systems is being performed by Project W-519.

\subsection{OPERATIONS, MAINTENANCE, AND SUPPORTING DOCUMENTS}

Operations, maintenance, and supporting documents are used to enable and control field activities. The Infrastructure Program has initiated Hanford Site infrastructure upgrade (i.e., design and construction) activities in support of the privatization contract (ORP 1998). Thus, many of the following sections are being developed and are intended as placeholders for future discussions and amendments to this document.

\subsubsection{Operations and Maintenance Concept}

Operations and maintenance concepts for water, electrical, roads, and liquid effluent/solid-waste disposal are developed from a combination of sources, including derivation from existing practices or previous concepts, adaptation of new procedures, ICDs, memoranda of agreement, and agreements in principle. Documents specific to the operation and maintenance of water, electrical, roads, and liquid effluent/solid-waste-disposal systems are added to and controlled as a part of the technical baseline as they are completed.

\subsubsection{Permits and Safety Authorizations}

Environmental permit planning documents are prepared or revised for the water, electrical, roads, and liquid effluent/solid-waste-disposal activities. In addition, the following Authorization Basis documents are being amended, as needed, to address interfaces with the Effluent Treatment Facility, Liquid Effluent Retention Facility, Treated Effluent Disposal Facility, and BNFL:

- HNF-SD-ETF-ASA-001, 200 Area Effluent Treatment Facility Auditable Safety Analysis Report (Campbell 2000)

- WHC-SD-C018H-HC-002, Hazard Categorization Report for the 200 Area Effluent Treatment Facility (Bourger 1994)

- HNF-SD-LEF-ASA-002, 242AL Liquid Effluent Retention Facility Auditable Safety Analysis (Galioto 1997a) 
- HNF-SD-WM-SAD-040, Liquid Effluent Retention Facility Final Hazard Category Determination (Galioto 1997b)

- WHC-SD-WM-SAR-023, 242-A Evaporator Safety Analysis Report (Campbell 1998).

\subsubsection{Process Limits}

Initial infrastructure support requirements were established in the ICDs for water, electrical, roads, and liquid effluent/solid-waste disposal. However, these initial requirements may be revised according to the privatization contract for Phase 1B.

\subsubsection{Operations and Maintenance Procedures}

The Infrastructure Program, DYN, and FH are developing operations and maintenance procedures for the water, electrical, roads, liquid effluent, and solid waste disposal systems, as needed. Procedure development occurs after Project W-519 has been completed and accepted by the RPP. Operations and maintenance procedures are considered technical baseline documents.

\subsubsection{Operations and Maintenance Records}

Operations and maintenance records include as a minimum calibration, process performance, and system surveillance documents. The Tank Farm Contractor, DYN, and FH develop procedures to govern recordkeeping activities associated with water, electrical, roads, liquid effluent, and solid-waste-disposal systems. 


\section{HNF-1901 REV 2}

This page intentionally left blank. 


\subsection{PRIVATIZATION CONTRACTOR INTERFACE}

This section summarizes privatization contract bases and technical baseline documentation. Privatization Contractor interface technical baseline documents are defined in ICDs in Appendix D.

In accordance with the TWRS Privatization Contract (ORP 1998), BNFL provides system capacity for waste treatment services for minimum order quantities of 6,000 units of LAW and 600 canisters of HLW glass. In a given year, BNFL can process up to 1,100 units of LAW and produce up to 120 canisters of HLW glass. Units of LAW are approximately equal to metric tons of sodium.

The Privatization Contractor provides the following services:

- Receive batches of the three LAW waste envelopes (A, B, and C)

- Receive batches of HLW feed (envelope D) into a Privatization Contractor-provided transfer system, tank, and facility

- Determine the degree of entrained solids, ${ }^{137} \mathrm{Cs},{ }^{99} \mathrm{~T},{ }^{90} \mathrm{Sr}$, and transuranic waste removal required to comply with contractual requirements and separate the waste into LAW and HLW fractions

- Treat and immobilize the LAW fraction and provide the final ILAW for return to the Tank Farm Contractor for disposal

- Treat and immobilize the HLW fraction and provide it to the Tank Farm Contractor for storage and ultimate disposal

- Protect materials from diversion and the facilities and materials from sabotage or other acts that can result in widespread exposure of workers and the public

- Deactivate Privatization Contractor facilities at the completion of waste treatment services.

Contractual expectations of the government (and hence the ORP/RPP team) and the Privatization Contractor are largely driven by interface descriptions identified in the privatization contract. Three interface descriptions identify that the Privatization Contractor is fully responsible for its generated dangerous waste, nondangerous solid waste, and liquid sanitary waste. The interface descriptions are part of the privatization contract and, as such, are not considered technical baseline documents.

Twenty interface descriptions are further defined through privatization ICDs. Two of these interfaces were eliminated through the results of system optimization studies. The remaining 18 privatization ICDs discussed in this section are grouped into one of four categories by the ORP/CH2M HILL Hanford Group, Inc./BNFL organizations: (1) Infrastructure, (2) Waste Feed, 
(3) Solid Waste Return, and (4) Environmental, Safety, and Health. The ICD subjects and categories are provided in Table 4-1.

Table 4-1. Interface Control Document Category Placement.

\begin{tabular}{|c|c|c|c|c|c|}
\hline \multirow{2}{*}{ ICD } & \multirow[b]{2}{*}{ ICD subject } & \multicolumn{4}{|c|}{ ICD catesory } \\
\hline & & $\begin{array}{l}\text { Infra- } \\
\text { structure }\end{array}$ & $\begin{array}{l}\text { Waste } \\
\text { Feed }\end{array}$ & $\begin{array}{l}\text { Solid Waste } \\
\text { Return }\end{array}$ & DS\&H \\
\hline 1 & Raw water & - & & & \\
\hline 2 & Potable water & $\bullet$ & & & \\
\hline 3 & Radioactive solid waste & & & - & \\
\hline 4 & Dangerous wastes & & & & - \\
\hline 5 & $\begin{array}{l}\text { Nonradioactive, } \\
\text { nondangerous liquid effluent }\end{array}$ & - & & & \\
\hline 6 & $\begin{array}{l}\text { Radioactive, dangerous liquid } \\
\text { effluent }\end{array}$ & $\bullet$ & & & \\
\hline 7 & Non-dangerous solid wastes & & & & - \\
\hline 8 & Liquid sanitary wastes & & & & $\bullet$ \\
\hline 9 & Land for siting & - & & & \\
\hline 10 & Deactivated facility and site & - & & & \\
\hline 11 & Electricity & - & & & \\
\hline 12 & Roads and rails & - & & & \\
\hline 14 & Immobilized high-level waste & & & 9 & \\
\hline 15 & $\begin{array}{l}\text { Immobilized low-activity } \\
\text { waste }\end{array}$ & & & - & \\
\hline 16 & Entrained solids & & $\bullet$ & & \\
\hline 19 & Low-activity waste feed & & - & & \\
\hline 20 & High-level waste feed & & 0 & & \\
\hline 22 & Air emissions & & & & - \\
\hline 23 & Waste treatability samples & & - & & \\
\hline 25 & Emergency response & & & & - \\
\hline 26 & Permits & & & & - \\
\hline
\end{tabular}

ES\&H = Environmental, Safety, and Health.

ICD = interface control document. 
HNF-1901 REV 2

\subsection{PRODUCT STORAGE AND DISPOSAL}

This section summarizes privatization contractor product bases and technical baseline documentation. Technical baseline documents are defined in Appendix E.

The Immobilized Waste Storage and Disposal Program is responsible for ensuring that the products from Privatization Contractor facilities are received, transported, stored, and disposed of properly. The term "products" is used only to describe vitrified waste. The products that are transferred back for management by the RPP contractor include the following:

- The ILAW, which is disposed of at the Hanford Site in a near-surface retrievable disposal facility

- The IHLW, which is stored at the Hanford Site and then shipped off Site for disposal.

Technical information listed for interfaces in Appendix E cover a wide variety of technical data. After final issuance of the ICDs, this technical information will be reexamined to eliminate information that is solely programmatic (i.e., information that does not represent products, processes, or SSCs, and to add other products other than vitrified waste, such as melters, and ventilation filters).

\subsection{PROCESS DEFINITION}

During Privatization Phase 1, LAW from the equivalent of approximately 12 DSTs is treated by the Privatization Contractor, and the resultant ILAW is disposed of on Site in a near-surface disposal facility. The Privatization Contractor also will treat the HLW. The resultant IHLW will be stored on Site, in the Hanford Site Canister Storage Building (CSB), and eventually shipped to an offsite disposal facility. Product streams containing entrained soljds may be returned from the Privatization Contractor to the Tank Farm Contractor. Negotiations between DOE and the Privatization Contractor define the return conditions for these product streams. Cesium-137 and ${ }^{90} \mathrm{Sr}$ capsules from previous Hanford Site operations are stored in the Waste Encapsulation and Storage Facility. The current baseline strategy is that processing of the capsules will be deferred to Phase 2.

\subsubsection{Immobilized Low-Activity Waste}

The Immobilized Waste Storage and Disposal Program's mission includes receiving ILAW packages produced by the Privatization Contractor, transporting the packages to a disposal site within the Hanford Site 200 Areas, and disposing of the packages in a manner that does not preclude retrieval. Project W-520 will construct a remote-handled trench for interim disposal. 


\subsubsection{Immobilized High-Level Waste}

The Immobilized Waste Storage and Disposal Program's mission includes receiving IHLW produced by the Privatization Contractor, transporting the products to an acceptable Hanford Site interim storage facility, and storing the products safely and economically until they can be shipped to a permanent facility. The primary objective is to provide onsite transportation systems and interim storage facilities for Privatization Phase 1 and 2 HLW products, which involves two primary projects. One project provides an onsite HLW product transportation system and retrofit of the CSB to accommodate Phase $1 \mathrm{HLW}$ products. The other project designs and constructs new facilities to accommodate Phase 2 HLW products.

\subsection{STRUCTURES, SYSTEMS, AND COMPONENTS}

The SSCs for product storage and disposal are defined to include the equipment and other systems required to transport, receive, store, and disposition products and waste from the Privatization Contractor. IHLW design requirements are found in WHC-SD-WM-DRD-012, Design Requirements Document for Interim Store Phase 1 Solidified High-Level Waste, Function 4.2.4.1.2 (Calmus 1996a). This and other design-basis documents in Appendix E identify specific facility components, instrumentation, control systems, and ancillary equipment required to receive and manage the Privatization Contractor products. The SSCs are further developed in the respective project-detailed design activities.

\subsubsection{Reliability, Availability, and Maintainability Risk Evaluation}

Risk planning, assessment, analysis, and management is used throughout the product storage and disposal activities to identify significant risk factors and formulate mitigation plans. The RAM risk analyses provide the basis for revising design requirements; anticipating spare equipment, training, and other project needs; and identifying potential programmatic impacts (e.g., scope, cost, schedule).

\subsection{OPERATIONS, MAINTENANCE, AND SUPPORTING DOCUMENTS}

Operations, maintenance, and supporting documents are those that are used to enable and control field activities. The Immobilized Waste Storage and Disposal Program recently initiated designs and engineering plans for the expected product storage and disposal activities. Thus, many of the following sections are only conceptual at this time or are intended to act as placeholders for future discussion and amendment of this document. 


\subsubsection{Operations and Maintenance Concept}

Operations and maintenance concepts for product storage and disposal are being developed from a combination of sources including derivation from existing practices or previous concepts (e.g., operating procedures for the Grout Disposal Facility vaults); adaptation of new procedures (e.g., modification of CSB maintenance procedures developed under Project W-379); and independent development of new practices (e.g., for the new ILAW disposal facility). Documents specific to operations and maintenance for product storage and disposal systems are added to and controlled by the technical baseline as the documents are completed.

\subsubsection{Permits and Safety Authorizations}

Environmental permit planning documents have been prepared for the product storage and disposal activities including HNF-SD-ENV-EE-003, Permitting Plan for the Immobilized Low-Activity Waste Project (Deffenbaugh et al. 1997); 70100-96-004, "Environmental Requirements Checklist for the High-Level Waste Storage Project Canister Storage Building" (Deffenbaugh 1996); and HNF-SD-ENV-EE-002, Environmental Permits and Approvals Plan for the High-Level Waste Interim Storage Project W-464 (Deffenbaugh 1998). For each applicable regulation, the permitting plans provide a summary of data requirements, a discussion of alternatives, a recommended implementation strategy, and an estimated cost of implementing the recommended alternative.

A comprehensive, graded approach to safety is being developed for the Immobilized Waste Storage and Disposal Program projects to integrate the appropriate safety inputs and requirements into the program's technical, cost, and schedule baselines. At this time, the RPP Authorization Basis for the Hanford Site does not include Projects W-464 or W-520, nor does it include future Privatization storage and disposal facilities. The Authorization Basis will be amended or another Authorization Basis will be developed to address these projects and interfaces with other Hanford Site projects and with the Privatization Contractor.

\subsubsection{Process Limits}

Process limits cannot be established at this time for product storage and disposal, primarily because the full characteristics, properties, and quantities of the ILAW and IHLW are not established yet. Process limits are developed after the privatization contract is finalized and more detailed designs are completed.

\subsubsection{Operations and Maintenance Procedures}

The Immobilized Waste Storage and Disposal Program develops operations and maintenance procedures for the product storage and disposal system. Procedures are developed as early as possible after design completion and finalized after project testing and acceptance by the Tank Farm Contractor. Operations and maintenance procedures are considered technical baseline documents. 


\subsubsection{Operations and Maintenance Records}

Operations and maintenance records include calibration, process performance, and system surveillance documents. After the product storage and disposal system has been defined, the Immobilized Waste Storage and Disposal Program develops procedures to govern recordkeeping activities. These records are technical baseline documents and are developed, collected, and maintained consistent with the project records.

\subsection{SECONDARY WASTE DEFINITION}

The product storage and disposal program is not generating secondary radioactive and solid waste now or in the near future. The secondary waste expected under this program is operational in nature and includes relatively small volumes of personal protective equipment, high-efficiency particulate air filters, and other material generated as a result of routine facility operations. 
This section summarizes utility service interface bases and technical baseline documentation. There are no current technical baseline documents listed in this document.

DYN provides the infrastructure support (utilities, transportation, general-purpose facilities, and sitewide services) for the Hanford Site, including the Tank Farm Contractor and the Privatization Contractor. This section briefly describes the scope of utility support to the TWR\&D mission.

The DYN Site Infrastructure mission is to provide safe, quality infrastructure services to the Hanford Site community that meet goals identified in HNF-SP-1169-98, FY 2000 Annual Work Plan for Infrastructure Programs WBS 6.2 (Dallas 1997). Specific infrastructure services that DYN provides to the Tank Farm Contractor include: site fabrication services, crane and rigging services, general-purpose facility management and maintenance services, utilities maintenance and operations, materials management, and laboratory operations support. They also provide calibration and nondestructive examination services; transportation; nonradioactive and solidwaste handling; environmental, safety, and health and quality assurance support; emergency services, including management of the Hanford Fire Department and Emergency Preparedness; and management of the landlord programs. Emergency services and landlord programs are covered by separate annual work plans.

Infrastructure support to the Privatization Contractor is addressed in privatization ICDs. DYN is responsible for providing the utilities (e.g., water, electricity), but is not responsible for installing the infrastructure or Privatization Contractor roads. The Tank Farm Contractor is responsible for the construction of the interface infrastructure. 
HNF-1901 REV 2

This page intentionally left blank. 


\subsection{CLOSURE}

This section summarizes tank farm facility closure bases and technical baseline documentation. There are no current technical baseline documents listed in this document.

Dangerous waste and radiologically contaminated treatment, storage, and disposal facilities supporting the TWR\&D mission require closure following the completion of their service. Closure is governed by DOE, Federal, and state regulations, which in most cases require comprehensive closure plans. Future site usage plans and guidance have been developed to guide decision making about postclosure site conditions. Tank farm closure is outside the Phase 1 mission. For this technical baseline summary, the most important closure information relates to privatization efforts and ILAW and IHLW storage and disposal systems. Information on these items is provided in this section, followed by information on closure of the general tank farm system and support facilities.

\subsection{PRIVATIZATION CONTRACTOR FACILITIES}

The Privatization Contractor is responsible for turning its facilities over to the ORP/RPP team after it has deactivated the systems, as required in the privatization contract (ORP 1998). Deactivated Privatization Contractor facilities are added to the inventory of Hanford Site facilities under transition and decontamination and decommissioning projects. Decisions regarding the final closure of Privatization Contractor facilities will be made once closure plans are developed and the DOE/EIS-0189, Tank Waste Remediation System, Hanford Site, Richland, Washington, Final Environmental Impact Statement (DOE and Ecology 1996) are updated or a separate environmental impact statement is written. BNFL-5193-ID-10, Interface Control Document for Deactivated Facility and Site (BNFL 2000) (see Section 5.0) provides the interface requirements for this activity.

\subsection{IMMOBILIZED WASTE FACILITIES}

After completion of the TWR\&D mission, including Phases 1 and 2, surface facilities for storing ILAW and IHLW are decontaminated (if necessary), razed, and/or filled to prevent subsidence. A standard Hanford Site surface barrier is assumed to be used as cover for the ILAW disposal facility and, if necessary, for the stabilized surface facilities (DOE/RW-0351P, Waste Acceptance - Systems Requirement Document [DOE 1996]).

\subsubsection{Immobilized Low-Activity Waste Facilities}

The ILAW facilities are maintained until all ILAW is received for ultimate disposal. At least 30 years of postclosure monitoring is provided, after which an approved closure plan is implemented and appropriate barriers are installed. Preparation of the ILAW facility closure plan and associated decision-making documentation (e.g., National Environmental Policy Act of 1969 ) is in the future. 


\section{HNF-1901 REV 2}

\subsubsection{Immobilized High-Level Waste Facilities}

The IHLW is to be temporarily stored in the CSB. Preparation of the CSB closure plan and associated decision-making documentation (e.g., National Environmental Policy Act of 1969) for closure of the CSB is in the future.

\subsection{TANK FARM SYSTEMS}

A summary of tank farm closure requirements is contained in DOE/ORP-2000-10 (ORP 2000a). The information source for the closure requirements is 62 FR 8693, "Record of Decision for the Tank Waste Remediation System, Hanford Site, Richland, Washington." Detailed requirements for closure of the tank farm systems will be developed as a future activity. 


\subsection{SAFE STORAGE}

\subsection{SCOPE}

The Tank Farm Contractor manages tank waste to minimize hazardous material exposure to the public and workers, to protect the environment, and to ensure cost-effective usage of storage facilities. This management involves oversight of a variety of SSCs used to store, monitor, confine, and transfer tank waste. This effort is separate from any waste retrieval, waste feed delivery, or handling of immobilized waste. Technical baseline information however is often applicable to both safe storage and tank waste retrieval and disposal missions. For example, Authorization Basis documents such as HNF-SD-WM-SAR-067, Tank Waste Remediation System Final Safety Analysis Report (CHG 2000c), and HNF-SD-WM-TSR-006, Tank Waste Remediation System Technical Safety Requirements (CHG 2000a) apply to all mission activities as new information is amended to them.

This section summarizes typical technical baseline information using the technical baseline subset descriptions. Specific technical information is contained in Appendix F, when not already noted in prior appendices. The information in Appendix $\mathrm{F}$ is cursory and represents the beginning of population loading of Safe Storage data represented by the summary designations below.

\subsection{REQUIREMENTS BASELINE}

\subsubsection{Permits and Licenses}

Various permits and licenses provide regulatory approval for specific tank farm operational activities, and provide requirements and commitments for design of modifications.

\subsubsection{Requirements Databases}

A variety of databases are used for tracking of safe storage requirements. These databases include the Authorization-Basis Requirements Management Interface (ARMI), the Hanford Site Technical Baseline Database, and the Environmental Requirements Management Interface (ERMI), which includes the standards/requirements identification documents. 


\subsection{DESIGN BASELINE}

\subsubsection{System Design Descriptions}

Design basis information is compiled in system design descriptions. This data is gathered from design reconstitution activities, facility walk-downs and equipment evaluation, reliability/availability/maintainability analyses, and facility modifications to ensure the safe storage mission.

\subsubsection{Drawing and Drawing Change Documents}

Essential and support drawings are identified in the Tank Farms Essential Drawing Plan, HNF-SD-WM-PC-002 (Domnoske-Rauch 2000). Change documents are issued as supplemental technical information to the drawings until they are incorporated within the drawing. Drawing change control is coordinated through engineering procedures in HNF-IP-0842 RPP Administration, Vol. IV Sec. 3.5 "Engineering Documents," and Sec. 4.25 "Engineering Drawings" (CHG 2000b). Drawing types include those that identify structure, system, and component configuration, and design information. This includes certified vendor information drawings which are controlled by HNF-IP-0842, RPP Administration, Vol. IV, Sec. 4.23 "Vendor Information" (CHG 2000b). Some drawings are used for operator aids, and supplemental information not used for configuration control, and is managed as Operations Baseline information.

\subsubsection{Specifications}

Design specifications are used in design input documents. Component procurement, construction, and installation specifications are used for facility modifications to ensure the safe storage mission. This includes upgrades and procurement of replacement material for maintenance activities.

\subsubsection{Design Review Packages}

Upgrade and maintenance design modifications require design verification. This design verification is conducted on a graded approach per HNF-IP-0842, RPP Administration, Vol. IV, Sec. 4.24 "Design Verification" (CHG 2000b). Documentation defining design through verification and review packages is used to support design changes and procurement activities, and identify how the technical baseline requirements are applied to the design.

\subsubsection{Acceptance Tests}

Acceptance tests are those tests that qualify adequacy of the design to design requirements. Test reports provide a record of system and component performance, and identify how the technical baseline requirements are satisfied in equipment operation. 


\subsection{OPERATIONS BASELINE}

\subsubsection{Staff Qualifications}

Staffs supporting the safe storage mission are qualified through meeting minimal educational and experience requirements, and after successful completion of general and specific training. Qualification programs for specific training are described in HNF-IP-0842, RPP Administration, Vol. III "Training" (CHG 2000b). Training records document satisfactory completion or meeting of qualification requirements.

\subsubsection{Authorization Basis Documents}

The safe storage mission is governed under authorization basis documents defined in HNF-IP-0842 RPP Administration, Vol. IV Sec. 5.4 "Unreviewed Safety Questions" (CHG 2000b). These include the Tank Waste Remediation System Final Safety Analysis Report (CHG 2000c), and the Tank Waste Remediation System Technical Safety Requirements

(CHG 2000d). New project activity safety analyses are amended to existing Authorization Basis documents to ensure consistency of analysis and safety control. Authorization Basis documents are supported by hazard analyses, and specific accident analysis evaluations. Implementation of Authorization Basis requirements and controls are through administrative procedures (e.g., HNF-IP-1266, Tank Farms Operations Administrative Controls (Coleman et al. 1997) and through operating procedures.

\subsubsection{Operating Procedures, Surveillance Sheets, and Maintenance Records}

Surveillance data sheets and operating procedures provide documentation for operative compliance with technical safety requirements and mission specific requirements. Maintenance records document reliability and maintainability of SSCs to mission goals and requirements, and establish a baseline for cost-effective management of the SSC.

\subsubsection{Process Tests and Control Documents}

Processing steps for both normal operation and changes are documented in process testing and control plans. These documents control key operational parameters to meet Authorization Basis requirements and achieve mission goals.

\subsubsection{Operational Databases}

Specific databases are used for documenting operational data to verify a variety of mission needs. Specific examples include the Master Equipment List, and calibration recall system managed through the Job Control System component listing. 
HNF-1901 REV 2

\subsubsection{Safety Equipment List}

The Safety Equipment List is a subset of the Master Equipment List and is currently managed under a separate technical information document (Zaman 1999). It further implements Authorization Basis requirements to system components.

\subsubsection{Spare Parts Documentation}

Spare and replacement parts are identified for essential operation, and cost-effective management of SSCs.

\subsubsection{Operational Specification Document}

Implementation of environmental and process control limits is identified in Operational Specification Documents. 
HNF-1901 REV 2

\begin{abstract}
APPENDIX A
EXAMPLE SELECTION CRITERIA FOR INCLUSION AS TECHNICAL BASELINE INFORMATION
\end{abstract}




\section{HNF-1901 REV 2}

This page intentionally left blank

A-ii 
Table A-1. Example Selection Criteria For Inclusion as Technical Baseline Information.

\begin{tabular}{|c|c|}
\hline \# & $\begin{array}{l}\text { Consider Related Technical Information as "Technical Baseline" if the Product, } \\
\text { Process, or Structure, System, and Component (SSC): }\end{array}$ \\
\hline 1 & Is required to support the Mission \\
\hline 2 & Needs to be controlled to validate its performance against requirements \\
\hline 3 & Satisfies safety or Authorization Basis requirements \\
\hline 4 & Relates to environmental requirements or regulations \\
\hline 5 & Satisfies natural phenomena criteria \\
\hline 6 & Should be controlled per a Risk Analysis \\
\hline 7 & Is a customer deliverable \\
\hline 8 & Implements a Basis requirement \\
\hline 9 & Provides a basis or justification for a configuration-controlled item \\
\hline 10 & Assigns or tracks ownership \\
\hline 11 & $\begin{array}{l}\text { Be used to design, acquire, install, construct, fabricate, use, operate, maintain, or change } \\
\text { a configuration-controlled item or information }\end{array}$ \\
\hline 12 & Assigns or controls interfaces \\
\hline 13 & Supports readiness activities \\
\hline 14 & Is managed per the quality assurance program plan \\
\hline 15 & Reflect as-built conditions that differ from design requirements \\
\hline 16 & Be related to specific predecessor or successor technical information \\
\hline 17 & Is called out specifically in work-breakdown structure documentation \\
\hline 18 & Requires periodic revision to be maintained current \\
\hline
\end{tabular}




\section{HNF-1901 REV 2}

This page intentionally left blank. 
HNF-1901 REV 2

APPENDIX B

WASTE FEED DELIVERY DOCUMENTS

B-i 


\section{HNF-1901 REV 2}

This page intentionally left blank.

B-ii 


\section{APPENDIX B \\ WASTE FEED DELIVERY DOCUMENTS}

\begin{tabular}{|l|l|l|}
\hline $\begin{array}{l}\text { Assigned Document } \\
\text { Number }\end{array}$ & Maintained Current? & Technical Baseline Subset \\
\hline B.1 & Yes & Operations \\
\hline
\end{tabular}

Document Name

Winkelman, W. D., M. R. Adams, T. M. Brown, J. W. Hunt, D. J. McCain, and L. J. Fergestrom, 1997, Fiscal Year 1997 - 1998 Waste Information Requirements Document, HNF-SD-WM-PLN-126, Rev.0, as amended, Lockheed Martin Hanford Corporation for Fluor Daniel Hanford, Inc., Richland, Washington.

\section{Responsible Organization}

CHG

Status of Preparation/Revision

The most recent full revision is included with the document name. Partial revisions are indicated by the notation, "as amended." The document will be revised as needed.

\section{Source Information Designation}

Annual plan for tank waste sampling activities with U.S. Department of Energy (DOE) and Ecology approval.

\section{Brief Summary of Content}

The Waste Information Requirements Document (formerly know as the Sample and Analysis Plan) describes characterization activities within the River Protection Project (RPP), which provides characterization information on Hanford Site waste tanks. The characterization information is required to perform operations and meet the commitments of RPP end users. These commitments are derived from the Hanford Federal Facility Agreement and Consent Order (Ecology et al. 1996), also known as the Tri-Party Agreement; the DOE/RL 94-0001, Recommendation 93-5 Implementation Plan (RL 1996) to the Defense Nuclear Facilities Safety Board (DNFSB); and other requirements.

Inter-related documents (successors and predecessors)

To be developed. 
HNF-1901 REV 2

\begin{tabular}{|l|l|l|}
\hline $\begin{array}{l}\text { Assigned Document } \\
\text { Number }\end{array}$ & Maintained Current? & Technical Baseline Subset \\
\hline B.2 & Yes & Operations \\
\hline
\end{tabular}

\section{Document Name}

Kupfer, M. J., A. L. Boldt, B. A. Higley, K. M. Hodgson, L. W. Shelton, B. C. Simpson, R. A. Watrous, S. L. Lambert, D. E. Place, R. M. Orme, G. L. Borsheim, N. G. Colton, M. D. LeClair, R. T. Winward, and W. W. Schulz, 1997, Standard Inventories of Chemicals and Radionuclides in Hanford Site Tank Wastes, HNF-SD-WM-TI-740, Rev. 0, as amended, prepared by Lockheed Martin Hanford Corporation for Fluor Daniel Hanford, Inc., Richland, Washington.

\section{Responsible Organization}

\section{CHG}

\section{Status of Preparation/Revision}

The most recent full revision is included with the document name. Partial revisions are indicated by the notation, "as amended." The document will be revised as needed.

\section{Source Information Designation}

Best-basis inventory of the chemicals and radiological contents of tank farm wastes.

\section{Brief Summary of Content}

This report presents work performed to date to establish standard global and tank-by-tank component inventory estimates. This work includes global inventory reconciliations for 26 nonradioactive components and 46 radionuclides that account for approximately 99 percent of the total tank waste inventory. To ensure that inventory values resulting from these evaluations are technically defensible and reproducible, every attempt is being made to document the basis (i.e., originating sources of assumptions, data, and background information that support these values).

Inter-related documents (successors and predecessors)

To be developed. 
HNF-1901 REV 2

\begin{tabular}{|l|l|l|}
\hline $\begin{array}{l}\text { Assigned Document } \\
\text { Number }\end{array}$ & Maintained Current? & Technical Baseline Subset \\
\hline B.3 & Yes & Operations \\
\hline Document Name \\
Tank Characterization Reports. See listing in Appendix G. \\
\hline Responsible Organization \\
CHG \\
\hline $\begin{array}{l}\text { Status of Preparation/Revision } \\
\text { Varies by report. }\end{array}$ \\
\hline $\begin{array}{l}\text { Source Information Designation } \\
\text { Best-basis inventories for the 177 individual DSTs and SSTs. } \\
\text { Brief Summary of Content } \\
\text { These 177 documents report the effort to provide waste inventory estimates that will serve as } \\
\text { standard characterization source terms for the various waste management activities. As part of } \\
\text { this effort, evaluations of the available information were performed for all 177 tanks, and a } \\
\text { best-basis inventory was established for each tank. This work follows the methodology that } \\
\text { was established by the standard inventory task identified in B.2. }\end{array}$ \\
\hline $\begin{array}{l}\text { Inter-related documents (successors and predecessors) } \\
\text { To be developed. }\end{array}$ \\
\hline
\end{tabular}


HNF-1901 REV 2

\begin{tabular}{|c|c|c|}
\hline $\begin{array}{l}\text { Assigned Document } \\
\text { Number }\end{array}$ & Maintained Current? & Technical Baseline Subset \\
\hline B.4 & Yes & Requirements \\
\hline \multicolumn{2}{|c|}{$\begin{array}{l}\text { Kirkbride, R. A., 2000, Tank Farm Contractor Operation and Utilization Plan, } \\
\text { HNF-SD-WM-SP-012, Rev. 2, CH2M HILL Hanford Group, Inc., Richland, Washington. }\end{array}$} & \\
\hline \multicolumn{3}{|c|}{ Responsible Organization } \\
\hline \multicolumn{3}{|c|}{$\begin{array}{l}\text { The most recent full revision is included with the document name. Partial revisions are } \\
\text { indicated by the notation, "as amended." The document will be revised as needed. }\end{array}$} \\
\hline \multicolumn{3}{|c|}{$\begin{array}{l}\text { The operating scenario and plans for the delivery of feed to the Privatization Contractor, } \\
\text { retrieval of waste from single- and double-shell tanks, and the overall process flowsheets. This } \\
\text { document is the source of the waste-feed delivery-system process. }\end{array}$} \\
\hline \multicolumn{3}{|c|}{$\begin{array}{l}\text { This document establishes the operating scenario and plans for the delivery of feed to the } \\
\text { Privatization Contractor, retrieval of waste from single-shell tanks, and the overall process } \\
\text { flowsheets for Privatization Phases } 1 \text { and } 2 \text {. This document consolidates previous versions of } \\
\text { the low-activity waste and high-level waste staging plans, the River Protection Project process } \\
\text { flowsheets, and the single-shell tank retrieval sequence. The existing plans and flowsheets are } \\
\text { updated with the most recent inventory and sludge washing data and are integrated with the } \\
\text { waste transfers projected by the operational waste volume projection. }\end{array}$} \\
\hline $\begin{array}{l}\text { Inter-related docum } \\
\text { To be developed. }\end{array}$ & essors and predecessor & \\
\hline
\end{tabular}


HNF-1901 REV 2

\begin{tabular}{|l|l|l|}
\hline $\begin{array}{l}\text { Assigned Document } \\
\text { Number }\end{array}$ & Maintained Current? & Technical Baseline Subset \\
\hline B.5 & Yes & Requirements \\
\hline
\end{tabular}

\section{Document Name}

Tollefson, K. S., and R. D. Potter, 2000, Waste Feed Delivery Environmental Permits and Approvals Plan, HNF-2401, Rev. 1, CH2M HILL Hanford Group, Inc., Richland, Washington.

\section{Responsible Organization}

\section{CHG}

\section{Status of Preparation/Revision}

The most recent full revision is included with the document name. Partial revisions are indicated by the notation, "as amended." The document will be revised as needed.

\section{Source Information Designation}

Description of environmental actions that may affect waste feed delivery activities.

\section{Brief Summary of Content}

The plan outlines alternative approaches to satisfying environmental standards and regulations. It describes the strategies needed to acquire permits and other regulatory approvals needed for waste feed delivery activities to proceed.

\section{Inter-related documents (successors and predecessors)}

Powell, P.A., 2000, Environmental Program Description for the Tank Farm Contractor, HNF-1773, Rev. 3, CH2M HILL Hanford Group, Inc., Richland, Washington. 
HNF-1901 REV 2

\begin{tabular}{|l|l|l|}
\hline $\begin{array}{l}\text { Assigned Document } \\
\text { Number }\end{array}$ & Maintained Current? & Technical Baseline Subset \\
\hline B.6 & Yes & Requirements \\
\hline Document Name \\
CHG, 2000, System Specification for the Double-Shell Tank System, HNF-SD-WM-TRD-007, \\
Rev. 0, Numatec Hanford Corporation for CH2M HILL Hanford Group, Inc., Richland, \\
Washington.
\end{tabular}


HNF-1901 REV 2

\begin{tabular}{|l|l|l|}
\hline $\begin{array}{l}\text { Assigned Document } \\
\text { Number }\end{array}$ & Maintained Current? & Technical Baseline Subset \\
\hline B.7 & Yes & Requirements \\
\hline
\end{tabular}

Document Names

Component Level 2 specifications for the Double-Shell Tank System:

CHG, 2000, Double-Shell Tank Diluent and Flush Subsystem Specification, HNF-4163, Rev. 0, Numatec Hanford Corporation for CH2M HILL Hanford Group, Inc., Richland, Washington.

CHG, 2000, Double-Shell Tank Maintenance and Recovery Subsystem Definition Report, HNF-4159, Rev. 0, Numatec Hanford Corporation for CH2M HILL Hanford Group, Inc., Richland, Washington.

CHG, 2000, Double-Shell Tank Mixer Pump Subsystem Specification, HNF-4164, Rev. 0, Numatec Hanford Corporation for CH2M HILL Hanford Group, Inc., Richland, Washington.

CHG, 2000, Double-Shell Tank Monitor and Control Subsystem, HNF-4155, Rev. 0, Numatec Hanford Corporation for CH2M HILL Hanford Group, Inc., Richland, Washington.

CHG, 2000, Double-Shell Tank Process Waste Sampling Subsystem Specification, HNF-4154, Rev. 0, Numatec Hanford Corporation for CH2M HILL Hanford Group, Inc., Richland, Washington.

CHG, 2000, Double-Shell Tank Transfer Piping Subsystem Specification, HNF-4161, Rev. 0, Numatec Hanford Corporation for CH2M HILL Hanford Group, Inc., Richland, Washington.

CHG, 2000, Double-Shell Tank Transfer Pump Subsystem Specification, HNF-4162, Rev. 0, Numatec Hanford Corporation for CH2M HILL Hanford Group, Inc., Richland, Washington.

CHG, 2000, Double-Shell Tank Transfer Valving Subsystem Specification, HNF-4160, Rev. 0, Numatec Hanford Corporation for CH2M HILL Hanford Group, Inc., Richland, Washington.

CHG, 2000, Double-Shell Tank Utilities Subsystem Specification, HNF-4157, Rev. 0, Numatec Hanford Corporation for CH2M HILL Hanford Group, Inc., Richland, Washington.

CHG, 2000, Double-Shell Tank Ventilation Subsystem Specification, HNF-5196, Rev. 0, Numatec Hanford Corporation for CH2M HILL Hanford Group, Inc., Richland, Washington.

Responsible Organization

CH2M HILL Hanford Group, Inc. 


\section{HNF-1901 REV 2}

\section{Status of Preparation/Revision}

Work is under way per fiscal year 1999 task plans.

\section{Source Information Designation}

N/A

\section{Brief Summary of Content}

Overall process design criteria for new and modified equipment supporting the waste feed delivery system.

\section{Inter-related documents (successors and predecessors)}

Claghorn, R. D., 1998, Performance Requirements for the Double-Shell Tank System: Phase 1, HNF-2168, Rev. 0, Numatec Hanford Corporation for Fluor Daniel Hanford, Inc., Richland, Washington.

Leonard, M. W., 2000, Engineering-Basis Document Review Supporting Double-Shell Tank System Specification, HNF-3350, Rev. 0, CH2M HILL Hanford Group, Inc., Richland, Washington.

Smith, D. F., and T. J. Conrads, 2000, Functional Analysis for Double-Shell Tank Subsystems, HNF-5136, Rev. 0, Numatec Hanford Corporation for CH2M HILL Hanford Group, Inc., Richland, Washington.

Hecht, S. L., 2000, Preliminary Heat Transfer Studies for the DST Transfer Piping, HNF-5442, Rev. 0, prepared by Fluor Hanford Corporation for CH2M HILL Hanford Group, Inc., Richland, Washington. 
HNF-1901 REV 2

\begin{tabular}{|l|l|l|}
\hline $\begin{array}{l}\text { Assigned Document } \\
\text { Number }\end{array}$ & Maintained Current? & Technical Baseline Subset \\
\hline B.8 & Yes & (See Individual List Below) \\
\hline
\end{tabular}

\section{Document Name}

Technical Baseline Documents for Project W-314

\section{Responsible Organization}

CHG

Status of Preparation/Revision

Various

Source Information Designation

Technical baseline documents related to the W-314 Project, Tank Farm Restoration and Safe Operations.

\section{Brief Summary of Content}

The project technical baseline documents are divided into 19 categories as identified below. The categories were developed in accordance with applicable engineering plans and procedures.

1. Functional Design Criteria (Requirements)

Boes, K. A., 1996b, Preliminary Design Requirements Document for Project W-314, Tank Farm Restoration and Safe Operations, WHC-SD-W314-DRD-001, Rev. 1, Westinghouse Hanford Company, Richland, Washington.

2. Conceptual Design Report (Design)

Boes, K. A., 1996a, Conceptual Design Report for Tank Farm Restoration and Safe Operations, Project W-314, WHC-SD-W314-CDR-001, Rev. 1, Fluor Daniel Hanford, Inc., Richland, Washington.

3. Alternate Design Study (Design)

Jacobson, R. W., 1997, Alternative Generation and Analysis Report, Tank Farm Monitoring and Master Pump Shutdown, Tank Farm Restoration and Safe Operation, W-314, HNF-SD-W314-AGA-007, Rev. 0, Lockheed Martin Hanford Corporation for Fluor Daniel Hanford, Inc., Richland, Washington. 
4. Final Design Report

TBD

5. Acceptance Test Plan (Design)

Hammers, J. S., 1999d, Test and Evaluation Plan for Project W-314 Tank Farm Restoration and Safe Operation, HNF-SD-W314-TEP-001, Rev. 3, Numatec Hanford Corporation for Lockheed Martin Hanford Corporation, Richland, Washington.

Hammers, J. S., 1999c, Project W-314 Specific Test and Evaluation Plan 241-AN-A Valve Pit, HNF-1733, Rev. 4, as amended, Numatec Hanford Corporation for Lockheed Martin Hanford Corporation, Richland, Washington.

HNF-XXXX through HNF-XXXX TBD (16 more STEPs are scheduled for release)

6. Operational Test Plan (Operations)

Hammers, J. S., 1999d, Test and Evaluation Plan for Project W-314 Tank Farm Restoration and Safe Operation, HNF-SD-W314-TEP-001, Rev. 3, Numatec Hanford Corporation for Lockheed Martin Hanford Corporation, Richland, Washington.

Hammers, J. S., 1999c, Project W-314 Specific Test and Evaluation Plan 241-AN-A Valve Pit, HNF-1733, Rev. 4, as amended, Numatec Hanford Corporation for Lockheed Martin Hanford Corporation, Richland, Washington.

HNF-XXXX through HNF-XXXX TBD (16 more STEPs are scheduled for release)

7. Operational Readiness Review/Acceptance Beneficial Use (Operations)

Warnick, T. L., 1997d, Project W-314 Master Pump Shutdown Upgrade Acceptance for Beneficial Use, HNF-SD-W314-ABU-001, Rev. 0, Fluor Daniel Northwest for Fluor Daniel Hanford, Inc., Richland, Washington.

Hammers, J. S., 1999a, Project W-314 241-AN-A Valve Pit Upgrade Acceptance for Beneficial Use, HNF-SD-W314-ABU-002, Rev. 0, Numatec Hanford Corporation for Lockheed Martin Hanford Corporation, Richland, Washington.

Hammers, J. S., 1999b, Project W-314 241-AN-B Valve Pit Upgrade Acceptance for Beneficial Use, HNF-SD-W314-ABU-003, Rev. 2, as amended, Numatec Hanford Corporation for Lockheed Martin Hanford Corporation, Richland, Washington.

Warnick, T. L., 1997e, Project W-314 SN-630 Transfer Line (AZ-02A to AN-B) Acceptance for Beneficial Use, HNF-SD-W314-ABU-004, Rev. 0, Fluor Daniel Northwest for Fluor Daniel Hanford, Inc., Richland, Washington. 
Warnick, T. L., 1997b, Project W-314 AX-B Valve Pit Upgrade Acceptance for Beneficial Use, HNF-SD-W314-ABU-005, Rev. 0, Fluor Daniel Northwest for Fluor Daniel Hanford, Inc., Richland, Washington.

Warnick, T. L., 1997g, Project W-314 SN-632 Transfer Line (AX-B to AZ-02A) Acceptance for Beneficial Use, HNF-SD-W314-ABU-006, Rev. 0, Fluor Daniel Northwest for Fluor Daniel Hanford, Inc., Richland, Washington.

Warnick, T. L., 1997c, Project W-314 AZ-02A Pump Pit Upgrade Acceptance for Beneficial Use, HNF-SD-W314-ABU-007, Rev. 0, Fluor Daniel Northwest for Fluor Daniel Hanford, Inc., Richland, Washington.

Warnick, T. L., 1997f, Project W-314 SN-634 Transfer Line (AB to AX-B) Acceptance for Beneficial Use, HNF-SD-W314-ABU-008, Rev. 0, Fluor Daniel Northwest for Fluor Daniel Hanford, Inc., Richland, Washington.

Warnick, T. L., 1997a, Project W-314 AB Valve Pit Upgrade Acceptance for Beneficial Use, HNF-SD-W314-ABU-009, Rev. 0, Fluor Daniel Northwest for Fluor Daniel Hanford, Inc., Richland, Washington.

8. Calculation/Analysis

TBD

9. Supporting Documents

TBD

10. Authorization Basis Changes (Operations)

CHG, 2000d, Tank Waste Remediation System Technical Safety Requirements, HNF-SD-WM-TSR-006, Rev. 1, as amended, CH2M HILL Hanford Group, Inc., Richland, Washington.

11. Reliability, Availability, Maintainability (RAM) Analysis

TBD

12. Constructability, Operability, and Implementability Analysis

TBD

13. Vendor Drawings/Instruction Manuals

TBD

14. System Design Description

TBD

15. Spare Parts List

TBD 


\section{HNF-1901 REV 2}

16. Control Drawings (Design)

Listing of project drawings for this project are in the project files.

17. Safety Equipment List (Operations)

Zaman, S. H., 1999, TWRS Facility Safety Equipment List, HNF-SD-WM-SEL-040, Rev. 4, as amended, Lockheed Martin Hanford Corporation, Richland, Washington.

18. Construction Specifications (Design)

Listing of construction specifications for this project is in the project files.

19. Fabrication Specifications (Design)

Listing of fabrication specifications for this project is in the project files.

Inter-related documents (successors and predecessors)

To be developed. 
HNF-1901 REV 2

\begin{tabular}{|c|c|c|}
\hline $\begin{array}{l}\text { Assigned Document } \\
\text { Number }\end{array}$ & Maintained Current? & Technical Baseline Subset \\
\hline B.9 & Yes & (See Individual List Below) \\
\hline \multicolumn{3}{|c|}{$\begin{array}{l}\text { Document Name } \\
\text { Technical Baseline Documents for Project W-211 }\end{array}$} \\
\hline \multicolumn{3}{|c|}{$\begin{array}{l}\text { Responsible Organization } \\
\text { CHG }\end{array}$} \\
\hline \multicolumn{3}{|c|}{ Status of Preparation/Revision } \\
\hline \multicolumn{3}{|c|}{$\begin{array}{l}\text { Source Information Designation } \\
\text { Technical baseline documents related to the W-211 Project, Initial Tank Retrieval System. }\end{array}$} \\
\hline \multicolumn{3}{|c|}{$\begin{array}{l}\text { The project technical baseline documents are divided into } 19 \text { categories as identified below. } \\
\text { The categories were developed in accordance with applicable engineering plans and } \\
\text { procedures. }\end{array}$} \\
\hline \multicolumn{3}{|c|}{ 1. Functional Design Criteria (Requirements) } \\
\hline \multicolumn{3}{|c|}{$\begin{array}{l}\text { Rieck, C. A., 1997c, Functional Design Criteria, Project W-211, Initial Tank Retrieval } \\
\text { Systems, HNF-SD-W211-FDC-001, Rev. 3, Numatec Hanford Corporation for Fluor Daniel } \\
\text { Hanford, Inc., Richland, Washington. }\end{array}$} \\
\hline \multicolumn{3}{|c|}{ 2. Conceptual Design Report (Design) } \\
\hline \multicolumn{3}{|c|}{$\begin{array}{l}\text { Rieck, C. A., 1994, Conceptual Design Report, Initial Tank Retrieval Systems for Project } \\
\text { W-211, WHC-SD-W211-CDR-001, Westinghouse Hanford Company, Richland, Washington. }\end{array}$} \\
\hline \multicolumn{3}{|c|}{ 3. Alternate Design Study (Design) } \\
\hline \multicolumn{3}{|l|}{ TBD } \\
\hline \multicolumn{3}{|c|}{ 4. Final Design Review Report } \\
\hline TBD W-211 is a phas & Each phase will reles & report as completed. \\
\hline
\end{tabular}




\section{Acceptance Test Plan}

TBD

6. Operational Test Plan

TBD

7. Operational Readiness Review/Acceptance Beneficial Use

TBD

8. Calculation/Analysis

Analysis is needed for each phase and the reports are issued as needed

9. Supporting Documents

Documents are released as needed for each phase

10. Authorization Basis Changes (Operations)

Rieck, C. A., 1998, Safety Assessment for Initial Tank Retrieval Systems-Project W-211, HNF-SD-W211-PSAD-001, Rev. 0, Numatec Hanford Corporation for Fluor Daniel Hanford, Inc., Richland, Washington.

11. Reliability, Availability, Maintainability (RAM) Analysis

TBD

12. Constructability, Operability, and Implementability Analysis

Constructability is checked during drawing/design review.

13. Vendor Drawings/Instruction Manuals

TBD

14. System Design Description

TBD

15. Spare Parts List

TBD

16. Control Drawings (Design)

Listing of project drawings is in the W-211 project file. 
17. Safety Equipment List (Operations)

Zaman, S. H., 1999, TWRS Facility Safety Equipment List, HNF-SD-WM-SEL-040, Rev. 4, as amended, Lockheed Martin Hanford Corporation, Richland, Washington.

18. Construction Specifications (Design)

Listing of project construction specifications are found in the W-211 project files.

19. Fabrication Specifications (Design)

Rieck, C. A., 1997d, Mobile Water Heater/Boiler Package, Procurement Specification W211-AP24-P2, Rev. 0, Numatec Hanford Corporation for Fluor Daniel Hanford, Inc., Richland, Washington.

Rieck, C. A., 1997a, Controlled Volume Metering Pump, Procurement Specification W211-AP24-P3, Rev. 0, Numatec Hanford Corporation for Fluor Daniel Hanford, Inc., Richland, Washington.

Rieck, C. A., 1997e, Steel Storage Tanks, Procurement Specification W211-AP24-P4, Rev. 0, Numatec Hanford Corporation for Fluor Daniel Hanford, Inc., Richland, Washington.

Rieck, C. A., 1997b, Diluent/Flush Pump, Procurement Specification W211-AP24-P5, Rev. 0, Numatec Hanford Corporation for Fluor Daniel Hanford, Inc., Richland, Washington.

Rieck, C. A., and M. E. McKinney, 1997, Procurement Specification, Slurry Transfer Pump, Specification W211-P001, Rev. 1, Numatec Hanford Corporation for Fluor Daniel Hanford, Inc., Richland, Washington.

Rieck, C. A., and M. E. McKinney, 1996a, Retrieval Control System Enclosures, Procurement Specification W211-P3, Rev. 0, Numatec Hanford Corporation for Fluor Daniel Hanford, Inc., Richland, Washington.

Rieck, C. A., and M. E. McKinney, 1996b, Waste Mobilization Mixer Pump, Procurement Specification W211-P005, Rev. 0, Numatec Hanford Corporation for Fluor Daniel Hanford, Inc., Richland, Washington.

Inter-related documents (successors and predecessors)

To be developed. 
HNF-1901 REV 2

\begin{tabular}{|l|l|l|}
\hline $\begin{array}{l}\text { Assigned Document } \\
\text { Number }\end{array}$ & Maintained Current? & Technical Baseline Subset \\
\hline B.10 & Yes & (See Individual List Below) \\
\hline
\end{tabular}

\section{Document Name}

Technical Baseline Documents for Project W-454

Responsible Organization

CHG

\section{Status of Preparation/Revision}

Various

\section{Source Information Designation}

Technical baseline documents related to the W-454 Project, AW Jumper Manifold Upgrade.

\section{Brief Summary of Content}

The project technical baseline documents are divided into 19 categories as identified below. The categories were developed in accordance with applicable engineering plans and procedures.

1. Functional Design Criteria (Requirements)

Mattichak, R. W., 1996b, Functional Design Criteria for AW Jumper Manifold Upgrade 241-AW Tank Farm Project W-454, WHC-SD-W454-FDC-001, Rev. 1, Westinghouse Hanford Company, Richland, Washington.

2. Conceptual Design Report (Design)

Mattichak, R. W., 1996a, Conceptual Design Letter Report for Project W-454, AW Jumper Manifold Upgrade, WHC-SD-W454-CDR-001, Rev. 0, Westinghouse Hanford Company, Richland, Washington.

3. Alternative Design Study

TBD

4. Final Design Review Report

TBD 
5. Acceptance Test Plan

TBD

6. Operational Test Plan

TBD

7. Operational Readiness Review/Acceptance Beneficial Use TBD

8. Calculation/Analysis

TBD

9. Supporting Documents

TBD

10. Authorization Basis Changes

TBD

11. Reliability, Availability, Maintainability (RAM) Analysis

TBD

12. Constructability, Operability, and Implementability Analysis

TBD

13. Vendor Drawings/Instruction Manuals

TBD

14. System Design Description

TBD

15. Spare Parts List

TBD

16. Control Drawings

TBD

17. Safety Equipment List

TBD

18. Construction Specifications

TBD

19. Fabrication Specifications

TBD

Inter-related documents (successors and predecessors)

To be determined. 
HNF-1901 REV 2

\begin{tabular}{|c|c|c|}
\hline $\begin{array}{l}\text { Assigned Document } \\
\text { Number }\end{array}$ & Maintained Current? & Technical Baseline Subset \\
\hline B.11 & Yes & (See Individual List Below) \\
\hline \multicolumn{3}{|c|}{$\begin{array}{l}\text { Document Name } \\
\text { Technical baseline documents for Project W-058 }\end{array}$} \\
\hline \multicolumn{3}{|c|}{ Responsible Organization } \\
\hline \multicolumn{3}{|c|}{ Status of Preparation/Revision } \\
\hline \multicolumn{3}{|c|}{ Technical baseline documents related to the W-058 Project, Cross Site Transfer Line. } \\
\hline \multicolumn{3}{|c|}{$\begin{array}{l}\text { The project technical baseline documents are divided into } 19 \text { categories as identified below. } \\
\text { The categories were developed in accordance with applicable engineering plans and } \\
\text { procedures. }\end{array}$} \\
\hline \multicolumn{3}{|c|}{ 1. Functional Design Criteria (Requirements) } \\
\hline \multicolumn{3}{|c|}{$\begin{array}{l}\text { Brantley, W. M., 1996, Functional Design Criteria for Project W-058, Replacement of the } \\
\text { Cross-Site Transfer System, WHC-SD-W058-FDC-001, Rev. 4, Westinghouse Hanford } \\
\text { Company, Richland, Washington. }\end{array}$} \\
\hline \multicolumn{3}{|c|}{ 2. Conceptual Design Report (Design) } \\
\hline \multicolumn{3}{|c|}{$\begin{array}{l}\text { Reep, I. E., 1992, Conceptual Design Report Replacement of the Cross-Site Transfer, } \\
\text { WHC-SD-W058-CDR-001, Rev. 0, Westinghouse Hanford Company, Richland, Washington. }\end{array}$} \\
\hline \multicolumn{3}{|c|}{ 3. Alternate Design Study } \\
\hline \multicolumn{3}{|l|}{ Not Applicable } \\
\hline \multicolumn{3}{|c|}{ 4. Final Design Review Report } \\
\hline Not Applicable & & \\
\hline
\end{tabular}


5. Acceptance Test Plan (Design)

Pacquet, E. A., 1997, Project W-058 Startup Test Plan, HNF-SD-W058-SUP-002, Rev. 1, Numatec Hanford Corporation for Fluor Daniel Hanford, Inc., Richland, Washington.

6. Operational Test Plan (Operations)

Pacquet, E. A., 1997, Project W-058 Startup Test Plan, HNF-SD-W058-SUP-002, Rev. 1, Numatec Hanford Corporation for Fluor Daniel Hanford, Inc., Richland, Washington.

7. Operational Readiness Review/Acceptance Beneficial Use (Operations)

Gilbert, J. L., 1998, Acceptance for Beneficial Use, Project W-058, HNF-SD-W058-ABU-001, Rev. 1, Numatec Hanford Corporation for Fluor Daniel Hanford, Inc., Richland, Washington.

8. Calculation/Analysis (Design)

Drawing No. H-2-822200, Sheets 1 and 2, Rev. 3, Drawing List (1998)

9. Supporting Documents

TBD

10. Authorization Basis Changes (Operations)

Kidder, R. J., 1996, Replacement of the Cross-Site Transfer System Preliminary Safety Analysis Report, WHC-SD-W058-PSAR-001, Rev.1, Westinghouse Hanford Company, Richland, Washington.

11. Reliability, Availability, Maintainability (RAM) Analysis

TBD

12. Constructability, Operability, and Implementability Analysis

Constructability was checked per Drawing Review/Approval Traveler

13. Vendor Drawings/Instruction Manuals

TBD

14. System Design Description (Design)

Draft has been issued as W-058 System Design Description; final release TBD

15. Spare Parts List

TBD 
16. Control Drawings

TBD

17. Safety Equipment List

TBD

18. Construction Specifications (Design)

W-058-C1, Rev. 1, Project Turnover Rev. 1 Technical Requirements Buried Pipeline for Replacement of the Cross Site Transfer System (1998)

W-058-C2, Rev. 2, Project Turnover Rev. 2 Construction Specification Pipeline Tie-ins for Replacement of the Cross Site Transfer System (1998)

W-058-C3, Rev. 3, Project Turnover Rev. 3 Construction Specification Diversion Box/Vent Station for Replacement of the Cross Site Transfer (1998)

W-058-C4, Rev. 0, Construction Specification Sagebrush Mitigation 600 Area (1996)

W-058-C5, Rev. 1, Project Turnover Rev 1 Construction Specification Flush System for Replacement of the Cross Site Transfer System (1998)

19. Fabrication Specifications (Design)

W-058-P1, Project Turnover Rev. 3 Procurement Specification Slurry Transfer Pump (1998)

W-058-P2, Rev. 6, Project Turnover Rev. 5 Procurement Specification Process Monitor and Control System (1998)

W-058-P5, Rev. 3, Project Turnover Rev. 3 Procurement Specification Process Instruments (1998)

W-058-P6, Rev. 2, As-Built Rev. 2 Procurement Specification Horizontal End Suction Centrifugal Pump (1998)

W-058-P8, Rev. 2, As-Built Rev. 2 Procurement Specification Compressed Air System (1998)

W-058-P9, Rev. 2, As-Built Rev. 2 Procurement Specification Air Operated Ball Values (1998)

W-058-P10, Project Turnover Rev. 1 Procurement Specification Rupture Disk/Relief Valve (1998)

W-058-P11, Rev. 1, Project Turnover Rev. 1 Procurement Specification Electric Circulation Heating System (1998) 


\section{HNF-1901 REV 2}

W-058-P12, Rev. 1, Project Turnover Rev. 1 Procurement Specification Chemical Feed System (1998)

W-058-P13 Rev. 1, Project Turnover Rev. 1 Procurement Specification, Calibration and Testing Laboratory Services (1998)

Inter-related documents (successors and predecessors)

To be developed. 
HNF-1901 REV 2

\begin{tabular}{|c|c|c|}
\hline $\begin{array}{l}\text { Assigned Document } \\
\text { Number }\end{array}$ & Maintained Current? & Technical Baseline Subset \\
\hline B. 12 & Yes & (See Individual List Below) \\
\hline \multicolumn{3}{|l|}{ Document Name } \\
\hline \multicolumn{3}{|c|}{ Responsible Organization } \\
\hline \multicolumn{3}{|c|}{ Status of Preparation/Revision } \\
\hline \multicolumn{3}{|c|}{ Source Information Designation } \\
\hline \multicolumn{3}{|c|}{$\begin{array}{l}\text { The project technical baseline documents are divided into } 19 \text { categories as identified below. } \\
\text { The categories were developed in accordance with applicable engineering plans and } \\
\text { procedures. }\end{array}$} \\
\hline \multicolumn{3}{|c|}{ 1. Functional Design Criteria (Requirements) } \\
\hline \multicolumn{3}{|c|}{$\begin{array}{l}\text { Keller, C. M., 1997, Functional Design Criteria for the Tank Farm Ventilation Upgrade, } \\
\text { Project W-030, HNF-SD-600-FDC-001, Rev. 4, Numatec Hanford Corporation for Fluor } \\
\text { Daniel Hanford, Inc., Richland, Washington. }\end{array}$} \\
\hline \multicolumn{3}{|c|}{$\begin{array}{l}\text { Nordquist, E. M., 1989, Conceptual Design Report, Tank Farm Ventilation Upgrade Cathodic } \\
\text { Protection System, WHC-SD-W030-CDR-001, Rev. 0, Westinghouse Hanford Company, } \\
\text { Richland, Washington. (Available in Project File only.) }\end{array}$} \\
\hline \multicolumn{3}{|c|}{ 3. Alternate Design Study } \\
\hline \multicolumn{3}{|l|}{ TBD } \\
\hline \multicolumn{3}{|c|}{ 4. Final Design Review Report (Design) } \\
\hline $\begin{array}{l}\text { Clifton, F. T., 1994, } P \\
\text { Westinghouse Hanfor }\end{array}$ & $\begin{array}{l}\text { O Final Review Report } \\
\text {, Richland, Washingto }\end{array}$ & D-W030-DRR-005, Rev. 0 \\
\hline
\end{tabular}


5. Acceptance Test Plan (Design)

Bowman, T. J., 1999, Acceptance Test Procedure for Cathodic Protection, Rectifier 31 , WHC-SD-W030-ATP-001, Rev. 1, Fluor Daniel Hanford, Inc., Richland, Washington.

Clifton, F. T., 1995a, Acceptance Test Procedure for Cathodic Protection, Rectifier 11, WHC-SD-W030-ATP-003, Rev. 0, Westinghouse Hanford Company, Richland, Washington.

Clifton, F. T., 1995b, Acceptance Test Procedure for Cathodic Protection, Rectifier 41, WHC-SD-W030-ATP-002, Rev. 0, Westinghouse Hanford Company, Richland, Washington.

Clifton, F. T., 1996a, Acceptance Test Procedure - Tank Farm and Miscellaneous Instrumentation, WHC-SD-W030-ATP-004, Rev. 0, Westinghouse Hanford Company, Richland, Washington.

Clifton, F. T., 1996b, Acceptance Test Procedure - Tank Farm Ventilation Upgrade W030; Primary Vent Filter Train, WHC-SD-W030-ATP-006, Rev. 0, Westinghouse Hanford Company, Richland, Washington.

Colosi, K. A., 1995, Acceptance Test Procedure Backup Power System, WHC-SD-W030-ATP-007, Rev. 0, Westinghouse Hanford Company, Richland, Washington.

Hill, L. F., 1995, Acceptance Test Procedure for W030 Monitor and Control System Software, WHC-SD-W030-ATP-011, Rev. 0, Westinghouse Hanford Company, Richland, Washington.

6. Operational Test Plan

TBD

7. Operational Readiness Review/Acceptance Beneficial Use TBD

8. Calculation/Analysis (Design)

Project W-030 summary calculations, contained in the project records

9. Supporting Documents

TBD

10. Authorization Basis (Operations)

CHG, 2000c, Tank Waste Remediation System Final Safety Analysis Report, HNF-SD-WM-SAR-067, Rev. 1, as amended, CH2M HILL Hanford Group, Inc., Richland, Washington. 
11. Reliability, Availability, Maintainability (RAM) Analysis

TBD

12. Constructability, Operability, and Implementability Analysis

TBD

13. Vendor Drawings/Instruction Manuals (Design)

H-2-131000, Drawing List

14. System Design Description

TBD

15. Spare Parts List (Operations)

Castleberry, J. L., 1998, Spare Parts List W-030 Tank Farm Ventilation Upgrade, HNF-1759, Rev. 1, Lockheed Martin Hanford Corporation for Fluor Daniel Hanford, Inc., Richland, Washington.

16. Control Drawings (Design)

H-2-131000, Drawing List

17. Safety Equipment List (Operations)

ECN 642900, HNF-SD-WM-SEL-040 (Zaman 1999)

18. Construction Specifications (Design)

W-030-C1, Rev. 1, As-Built Revision 1 Construction Specification-Site Preparation for Tank Farm Ventilation Upgrade (1998)

W-030-C2, Rev. 0, Construction Specification Tank Farm Ventilation Upgrade (1994)

19. Fabrication Specifications

TBD

Inter-related documents (successors and predecessors)

To be developed. 
HNF-1901 REV 2

\begin{tabular}{|c|c|c|}
\hline $\begin{array}{l}\text { Assigned Document } \\
\text { Number }\end{array}$ & Maintained Current? & Technical Baseline Subset \\
\hline B.13 & Yes & (See Individual List Below) \\
\hline \multicolumn{3}{|c|}{$\begin{array}{l}\text { Document Name } \\
\text { Technical baseline documents resulting from Project W-320 }\end{array}$} \\
\hline \multicolumn{3}{|c|}{ Responsible Organization } \\
\hline \multicolumn{3}{|c|}{$\begin{array}{l}\text { Status of Preparation/Revision } \\
\text { Various }\end{array}$} \\
\hline \multicolumn{3}{|c|}{ Source Information Designation } \\
\hline \multicolumn{3}{|c|}{$\begin{array}{l}\text { Brief Summary of Content } \\
\text { 1. Functional Design Criteria (Requirements) }\end{array}$} \\
\hline \multicolumn{3}{|c|}{$\begin{array}{l}\text { Bailey, J. W., 1998a, Functional Design Criteria for Tank 241-C-106 Waste Retrieval, Project } \\
\text { W-320, HNF-SD-W320-FDC-001, Rev. 5, Numatec Hanford Corporation for Fluor Daniel } \\
\text { Hanford, Inc., Richland, Washington. }\end{array}$} \\
\hline \multicolumn{3}{|c|}{$\begin{array}{l}\text { Bevins, R. R., 1998, Project W-320, Tank 241-C-106 Waste Retrieval Sluicing System } \\
\text { Testing Plan, WHC-SD-W320-TP-001, Rev. 1, Westinghouse Hanford Company, Richland, } \\
\text { Washington. }\end{array}$} \\
\hline \multicolumn{3}{|c|}{ 3. Calculation/Analysis (Design) } \\
\hline \multicolumn{3}{|c|}{$\begin{array}{l}\text { Bailey, J. W., 1998b, Project W-320, 241-C-106 Sluicing, Master Calculation List, HNF-2527, } \\
\text { Rev. 0, Numatec Hanford Corporation for Fluor Daniel Hanford, Inc., Richland, Washington. } \\
\text { 4. Authorization Basis (Operations) }\end{array}$} \\
\hline $\begin{array}{l}\text { CHG, 2000d, Tank W } \\
\text { HNF-SD-WM-SAR-0 } \\
\text { Washington. }\end{array}$ & $\begin{array}{l}\text { diation System Final Saf } \\
\text {, as amended, } \mathrm{CH} 2 \mathrm{M} \mathrm{H}\end{array}$ & $\begin{array}{l}\text { ysis Report, } \\
\text { ford Group, Inc., Richland, }\end{array}$ \\
\hline
\end{tabular}


5. Reliability, Availability, Maintainability (RAM) Analysis (Requirements)

Bevins, R. R., 1997, Severe Environmental Qualification and Life Expectancy of Immersible Pump System, HNF-SD-W320-ER-005, Rev. 0, Numatec Hanford Corporation for Fluor Daniel Hanford, Inc., Richland, Washington.

6. Vendor Drawings/Instruction Manuals

TBD

7. System Design Description (Design)

Carothers, K. G., S. D. Estey, N. W. Kirch, L. A., Stauffer, and J. W. Bailey 1999, Tank 241-C-106 Waste Retrieval Sluicing System Process Control Plan, HNF-SD-WM-PCP-013, Rev. 2, as amended Lockheed Martin Hanford Corporation for Fluor Daniel Hanford, Inc., Richland, Washington.

Graves, C. E., 1998, Design Basis Document, Project W-320, Tank 241-C-106, Sluicing Project Rebaselining Change Request New Scope, HNF-SD-W320-DB-001, Rev. 2, Numatec Hanford Corporation for Fluor Daniel Hanford, Inc., Richland, Washington.

8. Spare Parts List (Operations)

Bailey, J. W., 1998c, Project W-320, 241-C-106 Waste Retrieval Spare Parts List, HNF-2404, Rev. 1, Numatec Hanford Corporation for Fluor Daniel Hanford, Inc., Richland, Washington.

9. Control Drawings (Design)

Drawing No. H-2-818423, Drawing List, Rev. 2 (1998)

10. Safety Equipment List (Operations)

Bailey, J. W., and R. R. Bevins, 1997, Preliminary Engineering Analysis for Safety Class and Safety Significant WRSS Equipment, HNF-1559, Rev. 2, Numatec Hanford Corporation for Fluor Daniel Hanford, Inc., Richland, Washington.

11. Construction Specifications (Design)

W-320-C1, Rev. 1, As-Built Rev. 1 Tank 241-C-106 Sluicing Sitework/nterfarm Piping System (1998)

W-320-C2, Rev. 1, As-Built Rev. I Tank 241-C-106 Sluicing Equipment Removal System (1998)

W-320-C5, Rev. 1, as amended, As-Built Rev. 1 Tank 241-C-106 Sluicing C-Tank Farm (1998) 
W-320-C6, Rev. 2, As-Built Rev. 2 Tank 241-C-106 Sluicing Process Building Skid Fabrication (1998)

W-320-C7, Rev. 1, As-Built Rev. 1 Tank 241-C-106 Sluicing AY Tank Farm (1998)

12. Fabrication Specifications (Design)

W-320-P1, Rev. 0, Procurement Specification Exhaust Skid Ventilation Air Cleanup Trains (1995)

W-320-P2, Rev. 1, Procurement Specification Liquid Chiller, Skid Mounted (1995)

W-320-P3, Rev. 0, Procurement Specification Filter, High Efficiency Metal (1995)

W-320-P4, Rev. 0, Procurement Specification Heat Exchanger (1995)

W-320-P5, Rev. 0, Procurement Specification High Efficiency Mist Eliminator (1995)

W-320-P6, Rev. 0, Procurement Specification Fan, Recirculation Cooling (1995)

W-320-P7, Rev. 1, Procurement Specification Electric Heating Coils (1997)

W-320-P8, Rev. 0, Procurement Specification Moisture Separator (1995)

W-320-P17, Rev. 1, Tank 241-C-106 Sluicing (1995)

W-320-P18, Pump, Centrifugal (1997)

W-320-P20, Rev. 0, Procurement Specification Sluicer, Hydraulic Drive and Controls Tank 241-C-106 (1995)

W-320-P22, Air Compressor (1997)

W-320-P23, Air Drier (1997)

W-320-P24, Rev. 0, Procurement Specification Winch, Slurry/Sluice Pump (1995)

W-320-P32, Rev. 0, Procurement Specification Distribution Power Panels (1995)

W-320-P33, Rev. 0, Procurement Specification Electrical Equipment Skid AY-Farm (1995)

W-320-P34, Rev. 0, Procurement Specification for Electrical Equipment Skid C-Farm (1995)

W-320-P35, Rev. 0, Procurement Specification Seismic Shutdown System (1995)

W-320-P36, Rev. 0, Procurement Specification for Enclosure and Environmental Control (1995) 


\section{HNF-1901 REV 2}

W-320-P41, Rev. 0, Procurement Specification Isokinetic Air Sampling System (1995)

W-320—P44, Seismic Detectors (1997)

W-320-P45, Seismic Skids (1997)

Inter-related documents (successors and predecessors)

To be developed. 
HNF-1901 REV 2

\begin{tabular}{|c|c|c|}
\hline $\begin{array}{l}\text { Assigned Document } \\
\text { Number }\end{array}$ & Maintained Current? & Technical Baseline Subset \\
\hline B.14 & Yes & (See Individual List Below) \\
\hline \multicolumn{3}{|c|}{$\begin{array}{l}\text { Document Name } \\
\text { Technical baseline documents for Project W-151 }\end{array}$} \\
\hline \multicolumn{3}{|c|}{ Responsible Organization } \\
\hline \multicolumn{3}{|c|}{ Status of Preparation/Revision } \\
\hline \multicolumn{3}{|c|}{ Source Information Designation } \\
\hline \multicolumn{3}{|c|}{$\begin{array}{l}\text { The project technical baseline documents are divided into } 19 \text { categories as identified below. } \\
\text { The categories were developed in accordance with applicable engineering plans and } \\
\text { procedures. }\end{array}$} \\
\hline \multicolumn{3}{|c|}{ 1. Functional Design Criteria (Requirements) } \\
\hline \multicolumn{3}{|c|}{$\begin{array}{l}\text { Nordquist, E. M., 1997e, Tank 101-AZ Waste Retrieval System Functional Design Criteria, } \\
\text { HNF-SD-W151-FDC-001, Rev. 4, Numatec Hanford Corporation for Fluor Daniel Hanford, } \\
\text { Inc., Richland, Washington. }\end{array}$} \\
\hline \multicolumn{3}{|c|}{ 2. Conceptual Design Report (Design) } \\
\hline \multicolumn{3}{|c|}{$\begin{array}{l}\text { Lambert, D. L., 1990, Tank 101-AZ Waste Retrieval System Project W-151, } \\
\text { WHC-SD-W151-CDR-001, Rev. 0, Westinghouse Hanford Company, Richland, Washington. }\end{array}$} \\
\hline \multicolumn{3}{|c|}{ 3. Alternate Design Study (Requirements) } \\
\hline \multicolumn{3}{|c|}{$\begin{array}{l}\text { Shaw, C. P., 1992, Mixer Pump Study for Project W-151, WHC-SD-WM-ES-195, Rev. 0, } \\
\text { Westinghouse Hanford Company, Richland, Washington. }\end{array}$} \\
\hline \multicolumn{3}{|c|}{ 4. Final Design Review Report (Design) } \\
\hline $\begin{array}{l}\text { Crass, D. W., 1997, } F \\
\text { HNF-SD-W151-DRR } \\
\text { Hanford, Inc., Richlan }\end{array}$ & $\begin{array}{l}\text { sign Review Report Proje } \\
\text { 0, Lockheed Martin Ha } \\
\text { ngton. }\end{array}$ & $\begin{array}{l}\text { 51 Mixer Pump Procurement, } \\
\text { Corporation for Fluor Daniel }\end{array}$ \\
\hline
\end{tabular}


5. Acceptance Test Plan (Design)

Nordquist, E. M., 1995, Mixer Pump Test Specification Project W-151, WHC-SD-W151-TS-001, Rev. 0, Westinghouse Hanford Company, Richland, Washington.

Troyer, G. L., 1995, Project W-151 Flexible Receiver Radiation Detector System Acceptance Test Plan, WHC-SD-W151-ATP-001, Rev. 1, Westinghouse Hanford Company, Richland, Washington.

Nordquist, E. M., 1997a, Cathodic Protection Acceptance Test Procedure, HNF-SD-W 151-ATP-002, Rev. 1, Numatec Hanford Corporation for Fluor Daniel Hanford, Inc., Richland, Washington.

Nordquist, E. M., 1996, Project W-151 Test Plan, WHC-SD-W151-TP-003, Rev. 0, Westinghouse Hanford Company, Richland, Washington.

6. Operational Test Plan (Operations)

Staehr, T. W., 1999, Mixer Pump Test Plan for Double-Shell Tank AZ-101, HNF-SD-WM-PTP-027, Rev. 4, as amended, COGEMA Engineering Corporation for Fluor Daniel Hanford, Inc., Richland, Washington.

7. Operational Readiness Review/Acceptance Beneficial Use (Operations)

Nordquist, E. M., 1997b, Document Required for Acceptance for Beneficial Use of Project W-151, Tank 101-AZ Waste Retrieval System, HNF-SD-WM-ABU-023, Rev. 1, Numatec Hanford Corporation for Fluor Daniel Hanford, Inc., Richland, Washington.

8. Calculation/Analysis (Design)

Ziada, A. H., 1993, Stress Analysis of 4- to 6-Inch and 42-Inch Flexible Receiver, WHC-SD-W151-DA-003, Rev. 0, Westinghouse Hanford Company, Richland, Washington.

Ziada, A. H., 1994, W-151 Mixer Pump Energy Absorption Cylinder Analysis, WHC-SD-W151-DA-004, Rev. 0, Westinghouse Hanford Company, Richland, Washington.

Moody, D. A., 1996, 241-AZ-101 Mixer Pump Support Assembly, Extension Riser, and Spray Wash System Design Verification, WHC-SD-W151-DA-005, Rev. 0, Westinghouse Hanford Company, Richland, Washington.

Crass, D. W., 1996a, W-151 Steam Coil Fatigue Analysis for Mixer Pump Jet Loads, WHC-SD-W151-DA-006, Rev. 0, Westinghouse Hanford Company, Richland, Washington.

Crass, D. W., 1996b, W-151 Transfer Pump Stress Analysis for Mixer Pump Jet Loads, WHC-SD-W151-DA-007, Rev. 0, Westinghouse Hanford Company, Richland, Washington. 
Julyk, L. J., 1997, Evaluation of the Effect of Project W-151 Mixer Pump Jets on In-Tank Equipment Considering Potential Sludge Buildup on Equipment in Waste Tank 241-AZ-101, Hanford Site, Richland, Washington, HNF-SD-W151-DA-008, Rev. 0, Fluor Daniel Northwest, Inc., for Fluor Daniel Hanford, Inc., Richland, Washington.

9. Supporting Documents (Operations)

Shaw, C. P., 1992, Mixer Pump Study for Project W-151, WHC-SD-WM-ES-195, Rev. 0, Westinghouse Hanford Company, Richland, Washington.

Nordquist, E. M., 1997d, Project W-151 Project Field Verification Documentation, HNF-SD-W151-FVP-001, Rev. 0, as amended, Numatec Hanford Corporation for Fluor Daniel Hanford, Inc., Richland, Washington.

Nordquist, E. M., 1997c, Project W-151 Checkout - Testing Report, HNF-SD-W151-TRP-003, Rev. 0, Numatec Hanford Corporation for Fluor Daniel Hanford, Inc., Richland, Washington.

10. PSAR and Authorization Basis (Operations)

Bourger, F. H., and J. C. Conner, 1992, Preliminary Safety Analysis Report for Project W151, Tank 241-AZ-101 Waste Retrieval System, WHC-SD-W151-PSAR-001, Rev. 0, Westinghouse Hanford Company, Richland, Washington.

CHG, 2000c, Tank Waste Remediation System Final Safety Analysis Report, HNF-SD-WM-SAR-067, Rev. 1, as amended, CH2M HLL Hanford Group, Inc., Richland, Washington.

11. Reliability, Availability, Maintainability (RAM) Analysis

TBD

12. Constructability, Operability, and Implementability Analysis

TBD

13. Vendor Drawings/Instruction Manuals (Design)

Drawing No. H-2-78870, Rev. 4, TWRS Top Drawing Index (1998)

14. System Design Description (Design)

Kohlman, E. H., 1993, Project W-151 Supplemental Design Requirements, WHC-SD-W151-SDRD-001, Rev. 0, Westinghouse Hanford Company, Richland, Washington. 
15. Spare Parts List (Operations)

Nordquist, E. M., 1997b, Document Required for Acceptance for Beneficial Use of Project W-151, Tank 101-AZ Waste Retrieval System, HNF-SD-WM-ABU-023, Rev. 1, Numatec Hanford Corporation for Fluor Daniel Hanford, Inc., Richland, Washington.

16. Control Drawings (Design)

Drawing No. H-2-78870, Rev. 4, TWRS Top Drawing Index (1998)

Drawing No. H-2-79335, Rev. 2, TWRS - Drawing Index 4-6" Tank 101-AZ Waste Retrieval System (1998)

Drawing No. H-2-79207, Rev. 2, TWRS Drawing Index Tank AZ-101 Drywell/Profile Thermocouple (1997)

Drawing No. H-2-80936, Rev. 3, Area Map Drawing List (1997)

17. Safety Equipment List

TBD

18. Construction Specifications (Design)

W-151-C1, Rev. 1, As-Built Revision 1 Construction Specification for Tank 101-AZ Waste Retrieval Systems (1996)

W-151-C2, Rev. 1, As-Built Revision 1 Construction Specification for Tank 101-AZ Waste Retrieval Systems (1996)

W-151-C3, Rev. 1, As-Built Revision 1 Construction Specification for Tank 101-AZ Waste Retrieval Systems (1996)

19. Fabrication Specifications (Design)

WHC-S-0037, Rev. 3, Specification for High Pressure Hot Water System Project W-151 Tank 101-AZ Waste Retrieval System (1996)

WHC-S-0040, Rev. 1, Specification for Waste Mobilization Mixer Pump Project W-151 Tank AZ-101 Waste Retrieval System (1996)

WHC-S-0099, Rev. 2, Waste Tank Riser - Drywell Mapping Positioner (1994)

WHC-S-0410, Rev. 2, Procurement Specification for 241-AZ-101, W151 Suspended Fixture and Weld Inspection Camera System (1996)

V-W151-0002, Rev. 2, Specification for 101-AZ Mixer Pump Variable Speed Drive (1996) 
HNF-1901 REV 2

V-W151-0003, Rev. 1, Specification for Modifications for Grove Crane at 1100 (1996)

V-W151-0004, Rev. 1, Specification for 101-AZ Sludge Mobilization Monitor Cable and Cable Reel (1996)

Inter-related documents (successors and predecessors)

To be determined. 
HNF-1901 REV 2

\begin{tabular}{|l|l|l|}
\hline $\begin{array}{l}\text { Assigned Document } \\
\text { Number }\end{array}$ & Maintained Current? & Technical Baseline Subset \\
\hline B.15 & Yes & Requirements \\
\hline
\end{tabular}

\section{Document Name}

Dykes, A. A., J. K. Liming, B. K. Olson, 1999, Waste Feed Delivery System Phase I Preliminary Reliability, Availability, Maintainability Analysis, HNF-2863, Rev. 4, Numatec Hanford Corporation for Lockheed Martin Hanford Corporation, Richland, Washington.

\section{Responsible Organization}

\section{CHG}

\section{Status of Preparation/Revision}

The most recent full revision is included with the document name. Partial revisions are indicated by the notation, "as amended." The document will be revised as needed.

\section{Source Information Designation}

Reliability, availability, and maintainability risk evaluation report.

\section{Brief Summary of Content}

Initially, this reliability, availability, and maintainability (RAM) evaluation will include feed delivery only. This report presents the results of a first pass RAM assessment of the Phase I River Protection Project (RPP) Waste Feed Delivery System transfers to the Privatization Contractor. It is designed to be used for operational risk assessments to support the development of an operations and maintenance concept tailored to the unique requirements of the RPP Privatization Program.

\section{Inter-related documents (successors and predecessors)}

To be developed. 
HNF-1901 REV 2

\begin{tabular}{|c|c|c|}
\hline $\begin{array}{l}\text { Assigned Document } \\
\text { Number }\end{array}$ & Maintained Current? & Technical Baseline Subset \\
\hline B. 16 & Yes & Requirements \\
\hline \multicolumn{3}{|c|}{$\begin{array}{l}\text { Document Name } \\
\text { RL, 1993, Hanford Facility Dangerous Waste Part A Permit Application, DOE/RL-88-21, as } \\
\text { amended, U.S. Department of Energy, Richland Operations Office, Richland, Washington. }\end{array}$} \\
\hline \multicolumn{3}{|c|}{$\begin{array}{l}\text { Responsible Organization } \\
\text { CHG }\end{array}$} \\
\hline \multicolumn{3}{|c|}{$\begin{array}{l}\text { Status of Preparation/Revision } \\
\text { Part A was completed. }\end{array}$} \\
\hline \multicolumn{3}{|c|}{$\begin{array}{l}\text { Source Information Designation } \\
\text { Resource Conservation and Recovery Act of } 1976 \text { (RCRA) Part A permit for the tank farms as } \\
\text { a hazardous waste treatment, storage, and/or disposal facility (Section } 4.2 .2 .2 \text { for double-shell } \\
\text { tanks [DST] and Section 4.2.2.8 for single-shell tanks [SST]). }\end{array}$} \\
\hline \multicolumn{3}{|c|}{$\begin{array}{l}\text { Brief Summary of Content } \\
\text { Defines the acceptable waste codes, total volumes, and process volumes allowed for the DSTs } \\
\text { and SSTs. }\end{array}$} \\
\hline \multicolumn{3}{|c|}{ Inter-related documents (successors and predecessors) } \\
\hline
\end{tabular}


HNF-1901 REV 2

\begin{tabular}{|c|c|c|}
\hline $\begin{array}{l}\text { Assigned Document } \\
\text { Number }\end{array}$ & Maintained Current? & Technical Baseline Subset \\
\hline B. 17 & Yes & Requirements \\
\hline \multicolumn{3}{|c|}{$\begin{array}{l}\text { Document Name } \\
\text { Dexter, M. L., 1999, RPP Environmental Permits and Related Documentation, HNF-4474, } \\
\text { Rev. 4, CH2M HILL Hanford Group, Inc., Richland, Washington. }\end{array}$} \\
\hline \multicolumn{3}{|c|}{$\begin{array}{l}\text { Responsible Organization } \\
\text { CHG }\end{array}$} \\
\hline \multicolumn{3}{|c|}{$\begin{array}{l}\text { The most recent full revision is included with the document name. Partial revisions are } \\
\text { indicated by the notation, "as amended." The document will be revised as needed. }\end{array}$} \\
\hline \multicolumn{3}{|c|}{ Source Information Designation } \\
\hline \multicolumn{3}{|c|}{$\begin{array}{l}\text { This document contains the current list of environmental permits and related documentation } \\
\text { for River Protection Project (RPP) facilities and activities. RPP Environment, Safety, Health } \\
\text { and Quality Assurance maintain copies of these permits and related approvals. }\end{array}$} \\
\hline \multicolumn{3}{|c|}{ Inter-related documents (successors and predecessors) } \\
\hline
\end{tabular}


HNF-1901 REV 2

\begin{tabular}{|l|l|l|}
\hline $\begin{array}{l}\text { Assigned Document } \\
\text { Number }\end{array}$ & Maintained Current? & Technical Baseline Subset \\
\hline B.18 & No & Requirements \\
\hline
\end{tabular}

\section{Document Name}

Rasmussen, J. E., 1997, "Radioactive Air Emissions Notice of Construction (NOC) Project W-314, Tank Farm Restoration and Safe Operations," (letter 97-EAP-760 to A. W. Conklin, Washington State Department of Health and J. Leitch, U.S Environmental Protection Agency, December 8) U.S. Department of Energy, Richland Operations Office, Richland, Washington.

\section{Responsible Organization}

\section{CHG}

\section{Status of Preparation/Revision}

Delivered to Washington State Department of Health and U.S. Environmental Protection Agency, December 1997. Awaiting approval.

\section{Source Information Designation}

W-314 Project Air Permit with the U.S. Environmental Protection Agency, Washington State Department of Health, and Washington State Department of Ecology.

\section{Brief Summary of Content}

This document serves as a notice of construction, pursuant to the requirements of WAC 246-247, and as a request for approval to construct pursuant to 40 CFR 61.96 for the activities associated with Project.W-314, Tank Farm Restoration and Safe Operation.

\section{Inter-related documents (successors and predecessors)}

To be developed. 
HNF-1901 REV 2

\begin{tabular}{|c|c|c|}
\hline $\begin{array}{l}\text { Assigned Document } \\
\text { Number }\end{array}$ & Maintained Current? & Technical Baseline Subset \\
\hline B. 19 & No & Requirements \\
\hline \multicolumn{3}{|c|}{$\begin{array}{l}\text { Document Name } \\
\text { Bauer, J. D., 1994b, Notice of Construction Application Pursuant to Washington } \\
\text { Administrative Code } 246-247 \text { for Ventilation Upgrades, } 241-A Y \text { and } 241 \text {-AZ Tank Farms, } \\
\text { (Correspondence } 9400852 \text { to A. W. Conklin, Washington Department of Health, March 2), } \\
\text { U.S. Department of Energy, Richland Operations Office, Richland, Washington. }\end{array}$} \\
\hline \multicolumn{3}{|c|}{$\begin{array}{l}\text { Responsible Organization } \\
\text { CHG }\end{array}$} \\
\hline \multicolumn{3}{|c|}{$\begin{array}{l}\text { Status of Preparation/Revision } \\
\text { Awaiting approval. }\end{array}$} \\
\hline \multicolumn{3}{|c|}{$\begin{array}{l}\text { Air Permit for 241-AY and 241-AZ Ventilation Upgrade Project (includes Projects W-151 } \\
\text { and W-030) with the U.S. Environmental Protection Agency, Washington State Department } \\
\text { of Health, and Washington State Department of Ecology. }\end{array}$} \\
\hline \multicolumn{3}{|c|}{$\begin{array}{l}\text { This document is a notice of construction (NOC) for Ventilation Upgrades } 241-A Y \text { and } \\
241-A Z \text { Tank Farms. This NOC was submitted pursuant to WAC 246-247, "Radiation } \\
\text { Protection-Air Emissions." The NOC includes two projects: Project W-151 and } \\
\text { Project W-030. }\end{array}$} \\
\hline \multicolumn{3}{|c|}{ Inter-related documents (successors and predecessors) } \\
\hline
\end{tabular}


HNF-1901 REV 2

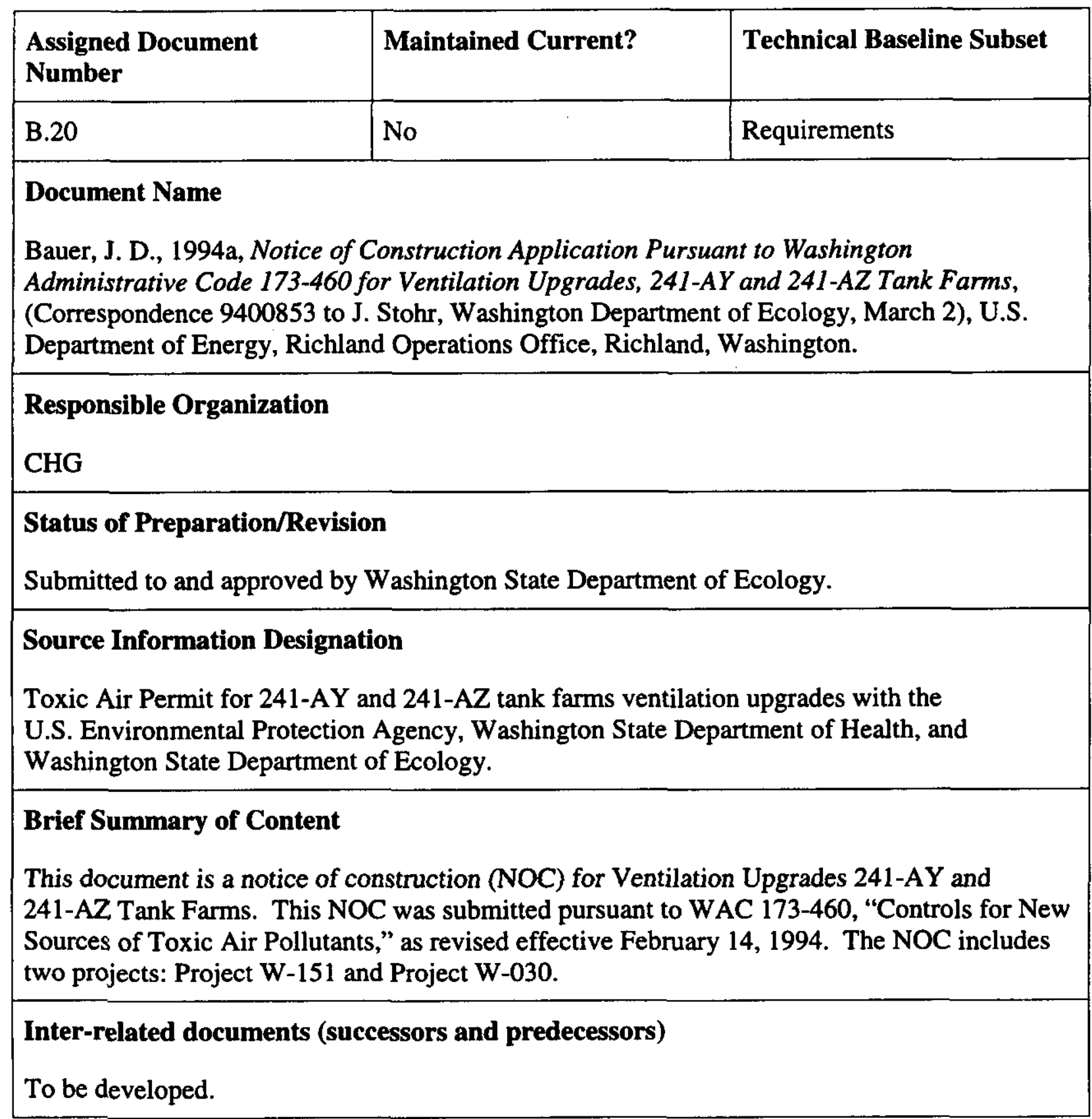


HNF-1901 REV 2

\begin{tabular}{|c|c|c|}
\hline $\begin{array}{l}\text { Assigned Document } \\
\text { Number }\end{array}$ & Maintained Current? & Technical Baseline Subset \\
\hline B. 21 & Yes & Operations \\
\hline \multicolumn{3}{|c|}{$\begin{array}{l}\text { Document Name } \\
\text { CHG, 2000c, Tank Waste Remediation System Final Safety Analysis Report, } \\
\text { HNF-SD-WM-SAR-067, Rev. 1, as amended, CH2M HILL Hanford Group, Inc., Richland, } \\
\text { Washington. }\end{array}$} \\
\hline $\begin{array}{l}\text { Responsible Organiz } \\
\text { CHG }\end{array}$ & & \\
\hline \multicolumn{3}{|c|}{$\begin{array}{l}\text { The most recent full revision is included with the document name. Partial revisions are } \\
\text { indicated by the notation, "as amended." The document will be revised as needed. }\end{array}$} \\
\hline \multicolumn{2}{|c|}{ Safety authorization basis for operation of the tank farms. } & \\
\hline \multicolumn{3}{|c|}{$\begin{array}{l}\text { The Final Safety Analysis Report (FSAR) provides a cohesive, integrated, and systematic } \\
\text { interim safety basis. The FSAR documents the basis for the conclusion tank farm facility } \\
\text { operations can be conducted safely complying with the requirements of DOE Order } 5480.23 \text {, } \\
\text { Nuclear Safety Analysis Reports. }\end{array}$} \\
\hline \multicolumn{3}{|c|}{$\begin{array}{l}\text { Implementation of the controls established by this FSAR enhances the safe operation of the } \\
\text { Tank Farm Contractor facilities. It also provides a sound basis for conducting effective } \\
\text { unreviewed safety question evaluations to ensure continued safe operations. }\end{array}$} \\
\hline Inter-related docume & cessors and predecessor & \\
\hline
\end{tabular}


HNF-1901 REV 2

\begin{tabular}{|l|l|l|}
\hline $\begin{array}{l}\text { Assigned Document } \\
\text { Number }\end{array}$ & Maintained Current? & Technical Baseline Subset \\
\hline B.22 & Yes & Operations \\
\hline
\end{tabular}

\section{Document Name}

CHG, 2000d, Tank Waste Remediation System Technical Safety Requirements, HNF-SD-WM-TSR-006, Rev. 1, as amended, CH2M HILL Hanford Group, Inc., Richland, Washington.

\section{Responsible Organization}

\section{CHG}

\section{Status of Preparation/Revision}

The most recent full revision is included with the document name. Partial revisions are indicated by the notation, "as amended." The document will be revised as needed.

\section{Source Information Designation}

Technical safety requirements.

\section{Brief Summary of Content}

The Tank Farm Contractor technical safety requirements (TSR) for the facilities within the scope of the final safety analysis report (FSAR) define acceptable conditions, safe boundaries, bases, and management or administrative controls required ensuring safe operation during waste storage, transfer, and characterization. The TSRs are based on the preventive and mitigative features determined to be essential in the FSAR, complying with DOE Order 5480.22 Technical Safety Requirements.

Inter-related documents (successors and predecessors)

To be developed. 
HNF-1901 REV 2

\begin{tabular}{|l|l|l|}
\hline $\begin{array}{l}\text { Assigned Document } \\
\text { Number }\end{array}$ & Maintained Current? & Technical Baseline Subset \\
\hline B.23 & Yes & Operations \\
\hline
\end{tabular}

\section{Document Name}

Zaman, S. H., 1999, TWRS Facility Safety Equipment List, HNF-SD-WM-SEL-040, Rev. 4, as amended, Lockheed Martin Hanford Corporation, Richland, Washington.

\section{Responsible Organization}

$\mathrm{CHG}$

\section{Status of Preparation/Revision}

The most recent full revision is included with the document name. Partial revisions are indicated by the notation, "as amended." The document will be revised as needed.

\section{Source Information Designation}

Facility safety equipment.

\section{Brief Summary of Content}

The safety classification in this document supports the Tank Farm Contractor FSAR. The barriers and administrative controls in the FSAR to prevent or mitigate the accidents analyzed are the basis for the selection of the safety classification described.

This document provides the Tank Farm Contractor facility with the information requirements to support the occurrence reporting activities for operations and establishes the operating and maintenance systems, structures, and components important to safety.

Inter-related documents (successors and predecessors)

To be developed. 
HNF-1901 REV 2

\begin{tabular}{|l|l|l|}
\hline $\begin{array}{l}\text { Assigned Document } \\
\text { Number }\end{array}$ & Maintained Current? & Technical Baseline Subset \\
\hline B.24 & Yes & Requirements \\
\hline
\end{tabular}

\section{Document Name}

Orme, R. M., 1999a, Waste Feed Delivery Technical Basis, Volume II, HNF-1939, Rev. 0, Numatec Hanford Corporation for Fluor Daniel Hanford, Inc., Richland, Washington.

\section{Responsible Organization}

\section{CHG}

\section{Status of Preparation/Revision}

The most recent full revision is included with the document name. Partial revisions are indicated by the notation, "as amended." The document will be revised as needed.

\section{Source Information Designation}

Chemical property listing for planned retrieval waste streams.

\section{Brief Summary of Content}

This is the second volume of a four-volume set describing waste feed technical requirements. This flowsheet provides process parameters for the delivery of waste from three specific tanks, including a discussion of the proposed scenario for retrieving and delivering the waste, chemical behavior and characteristics of the waste in those tanks, and related energy considerations.

\section{Inter-related documents (successors and predecessors)}

Orme, R. M., 1999a, Waste Feed Delivery Technical Basis, Volume II, Addendum 1-1, "Waste Feed Delivery Flow Sheet for 241-AZ-101," HNF-1939, Rev. 0a, Numatec Hanford Corporation for Fluor Daniel Hanford, Inc., Richland, Washington.

Orme, R. M., 1999b, Waste Feed Delivery Technical Basis, Volume II, Addendum 2-1, "Waste Feed Delivery Flow Sheet for 241-AN-105," HNF-1939, Rev. Ob, Numatec Hanford Corporation for Fluor Daniel Hanford, Inc., Richland, Washington.

Orme, R. M., 1999c, Waste Feed Delivery Technical Basis, Volume II, Addendum 3-1, "Waste Feed Delivery Flow Sheet for 241-AN-104," HNF-1939, Rev. Oc, prepared by Numatec Hanford Corporation for Fluor Daniel Hanford, Inc., Richland, Washington. 
HNF-1901 REV 2

\begin{tabular}{|l|l|l|}
\hline $\begin{array}{l}\text { Assigned Document } \\
\text { Number }\end{array}$ & Maintained Current? & Technical Baseline Subset \\
\hline B.25 & Yes & Requirements \\
\hline
\end{tabular}

Document Name

Rasmussen, O. R., 1999, Waste Feed Delivery Technical Basis, Volume III, "Waste Feed Delivery System Description," HNF-1939, Rev. 0A, prepared by Lockheed Martin Hanford Corporation, Richland, Washington.

Responsible Organization

CHG

\section{Status of Preparation/Revision}

The most recent full revision is included with the document name. Partial revisions are indicated by the notation, "as amended." The document will be revised as needed.

Source Information Designation

Configured hardware and facility description for retrieval baseline planning.

\section{Brief Summary of Content}

This is the third volume of a four-volume waste set describing feed technical requirements. This volume describes the tank farm infrastructure that supports waste feed delivery. It includes the existing tank farm system, and retrieval and transfer systems to be built by projects W-211, W-314, and W-509. This volume set includes a large set of Appendices A-J listing technical baseline information.

Inter-related documents (successors and predecessors)

To be developed. Subset information within this document (e.g., drawings) will be listed separately in the technical baseline database version. 
HNF-1901 REV 2

\begin{tabular}{|c|c|c|}
\hline $\begin{array}{l}\text { Assigned Document } \\
\text { Number }\end{array}$ & Maintained Current? & Technical Baseline Subset \\
\hline B.26 & Yes & Requirements \\
\hline \multicolumn{3}{|c|}{$\begin{array}{l}\text { Document Name } \\
\text { Carlson, A. B., P. J. Certa, A. A. Dykes, J. K. Liming, B. K. Olson, J. G. Stampelos, and } \\
\text { M. M. Jennings, 1999, Waste Feed Delivery Technical Basis, Volume IV Waste Feed Delivery } \\
\text { Operations and Maintenance Concept, HNF-1939, Vol. IV, Rev. 0, Fluor Daniel Hanford, } \\
\text { Inc., Richland, Washington. }\end{array}$} \\
\hline \multicolumn{3}{|l|}{ Responsible Organizat } \\
\hline \multicolumn{3}{|c|}{$\begin{array}{l}\text { The most recent full revision is included with the document name. Partial revisions are } \\
\text { indicated by the notation, "as amended." The document will be revised as needed. }\end{array}$} \\
\hline \multicolumn{3}{|c|}{ Source Information Designation } \\
\hline \multicolumn{3}{|c|}{$\begin{array}{l}\text { This is the fourth volume of a four-volume set describing waste feed technical requirements. } \\
\text { This document describes how the waste feed delivery physical system will be operated and } \\
\text { maintained, identifies existing constraints that must be satisfied, describes operation and } \\
\text { maintenance functions and requirements, provides a traceable basis for the allocation of } \\
\text { operation and maintenance resources, and addresses the ability to meet the waste feed delivery } \\
\text { schedule for the three source tanks. }\end{array}$} \\
\hline
\end{tabular}


HNF-1901 REV 2

This page intentionally left blank. 
HNF-1901 REV 2

APPENDIX C

INFRASTRUCTURE SUPPORT DOCUMENTS

C-i 


\section{HNF-1901 REV 2}

This page intentionally left blank.

C-ii 
HNF-1901 REV 2

\begin{tabular}{|l|l|l|}
\hline $\begin{array}{l}\text { Assigned Document } \\
\text { Number }\end{array}$ & Maintained Current? & Technical Baseline Subset \\
\hline C. 1 & No & Requirements \\
\hline
\end{tabular}

\section{Document Name}

Galbraith, J. D., and P. M. Daling (PNNL), 1997, Decision Document: Phase 1 Intermediate Waste Feed Staging System Design Requirements, HNF-SD-WM-TI-800, Rev. 0, Numatec Hanford Corporation for Fluor Daniel Hanford, Inc., Richland, Washington.

\section{Responsible Organization}

\section{CHG}

\section{Status of Preparation/Revision}

The most recent full revision is included with the document name. Partial revisions are indicated by the notation, "as amended." The document will be revised as needed.

\section{Source Information Designation}

Intermediate feed staging.

\section{Brief Summary of Content}

In FY 1996, a Tank Waste Remediation System Project Decision Board was convened to select a strategy for preparing feed to transfer to the low-activity waste Private Contractor. The Decision Board selected a strategy referred to as "Intermediate Feed Staging." In this strategy, the Hanford Site Management and Integration contractor would transfer low-level waste feed to an intermediate feed staging tank where it would be sampled to validate that the material is within the Private Contractor's feed specification. Once the validation was completed, the feed material would be transferred to the Private Contractor's feed tanks. This document provides design requirements for modification to Tanks 241-AP-102 and 241-AP-104.

Inter-related documents (successors and predecessors)

To be developed. 
HNF-1901 REV 2

\begin{tabular}{|l|l|l|}
\hline $\begin{array}{l}\text { Assigned Document } \\
\text { Number }\end{array}$ & Maintained Current? & Technical Baseline Subset \\
\hline C. 2 & Yes & (See Individual List Below) \\
\hline
\end{tabular}

\section{Document Name}

Various

\section{Responsible Organization}

\section{CHG}

\section{Status of Preparation/Revision}

Various

\section{Source Information Designation}

Technical baseline documents related to the W-519 Project, TWRS Privatization Phase 1 Infrastructure Support

\section{Brief Summary of Content}

The project technical baseline documents are divided into 19 categories as identified below. The categories were developed in accordance with applicable engineering plans and procedures.

1. Functional Design Criteria (Requirements)

Parazin, R. J., 1998a, Design Requirements Document for TWRS Privatization Phase 1 Liquid Effluent Transfer Systems, HNF-SD-WM-DRD-014, Rev. 1, as amended, Numatec Hanford Corporation for Fluor Daniel Hanford, Inc., Richland, Washington.

Parazin, R. J., 1998b, Design Requirements Document for TWRS Privatization Phase 1 Raw and Potable Water Supply Systems, HNF-SD-WM-DRD-015, Rev. 1, Numatec Hanford Corporation for Fluor Daniel Hanford, Inc., Richland, Washington.

Parazin, R. J., 1998c, Design Requirements Document for TWRS Privatization Phase 1 Site Development, HNF-SD-WM-DRD-013, Rev. 2, Numatec Hanford Corporation for Fluor Daniel Hanford, Inc., Richland, Washington.

Singh, G., 1997e, Design Requirements Document, Design Requirements for the Phase 1 Privatization Electrical Power System, WHC-SD-WM-DRD-011, Rev. 1, Numatec Hanford Corporation for Fluor Daniel Hanford, Inc., Richland, Washington. 
2. Conceptual Design Report (Design)

Singh, G., 1997a, Conceptual Design Report, TWRS Privatization Phase I, Electrical Power System Subproject W-503, HNF-SD-W503-CDR-001, Rev. 0, Numatec Hanford Corporation for Fluor Daniel Hanford, Inc., Richland, Washington.

Singh, G., 1997b, Conceptual Design Report, TWRS Privatization Phase 1, Liquid Effluent Transfer Systems Subproject W-506, HNF-SD-W506-CDR-001, Rev. 0, Numatec Hanford Corporation for Fluor Daniel Hanford, Inc., Richland, Washington.

Singh, G., 1997c, Conceptual Design Report, TWRS Privatization Phase I, Raw and Potable Water, Subproject W-504, HNF-SD-W504-CDR-001, Rev. 0, Numatec Hanford Corporation for Fluor Daniel Hanford, Inc., Richland, Washington.

Singh, G., 1997d, Conceptual Design Report, TWRS Privatization Phase 1, Site Development and Roads, Subproject W-505, HNF-SD-W505-CDR-001, Rev. 0, Numatec Hanford Corporation for Fluor Daniel Hanford, Inc., Richland, Washington.

Singh, G., 1997e, Design Requirements Document, Design Requirements for the Phase 1 Privatization Electrical Power System, WHC-SD-WM-DRD-011, Rev. 1, Numatec Hanford Corporation for Fluor Daniel Hanford, Inc., Richland, Washington.

Singh, G., and D. L. Fort, 1997, Summary Conceptual Design Report for Tank Waste Remediation System Privatization Phase 1 Infrastructure Support, Project W-519, HNF-1939, Rev. 0, Numatec Hanford Corporation for Fluor Daniel Hanford, Inc., Richland, Washington.

3. Alternative Design Study

TBD

4. Final Design Review Report

TBD

5. Acceptance Test Plan

TBD

6. Operational Test Plan reports

TBD

7. Operational Readiness Review/Acceptance Beneficial Use

TBD 
8. Calculation/Analysis

TBD

9. Supporting Documents (Requirements)

Parazin, R. J., 1998d, TWRS Privatization Phase 1, Master Site Plan, HNF-SD-TWR-DSD-001, Rev. 1, Numatec Hanford Corporation for Fluor Daniel Hanford, Inc., Richland, Washington.

Shade, J. W., 1997, TWRS Phase 1 Privatization Site Environmental Baseline and Characterization Plan, HNF-SD-TWR-EV-001, Rev. 0, prepared by Numatec Hanford Corporation for Fluor Daniel Hanford, Inc., Richland, Washington.

10. PSAR and Authorization Basis

TBD

11. Reliability, Availability, Maintainability (RAM) Analysis

TBD

12. Constructability, Operability, and Implementation

TBD

13. Vendor Drawings/Instruction Manuals

TBD

14. System Design Description

TBD

15. Spare Parts List

TBD

16. Control Drawings

TBD

17. Safety Equipment List

TBD 
HNF-1901 REV 2

18. Construction Specifications

TBD

19. Fabrication Specifications

TBD

Inter-related documents (successors and predecessors)

To be developed 


\section{HNF-1901 REV 2}

This page intentionally left blank.

C-6 
HNF-1901 REV 2

\section{APPENDIX D}

PRIVATIZATION CONTRACTOR INTERFACE DOCUMENTS

D-i 


\section{HNF-1901 REV 2}

This page intentionally left blank.

D-ii 
HNF-1901 REV 2

\begin{tabular}{|c|c|c|}
\hline $\begin{array}{l}\text { Assigned Document } \\
\text { Number }\end{array}$ & Maintained Current? & Technical Baseline Subset \\
\hline D.1 & Yes & Requirements \\
\hline \multicolumn{3}{|l|}{ Document Name } \\
\hline \multicolumn{3}{|c|}{$\begin{array}{l}\text { BNFL, 2000, Interface Control Document for Raw Water, BNFL-5193-ID-01, Rev. 4, as } \\
\text { amended, BNFL Inc., Richland, Washington. }\end{array}$} \\
\hline \multicolumn{3}{|c|}{ Responsible Organization } \\
\hline \multicolumn{3}{|c|}{ BNFL Inc., CHG, and DOE } \\
\hline \multicolumn{3}{|c|}{ Status of Preparation/Revision } \\
\hline \multicolumn{3}{|c|}{ Draft. Work is continuing on final. } \\
\hline \multicolumn{3}{|c|}{ Source Information Designation } \\
\hline \multicolumn{3}{|c|}{ Establishes interfaces with Privatization Contractor for the delivery and use of raw water. } \\
\hline \multicolumn{3}{|c|}{ Brief Summary of Content } \\
\hline \multicolumn{3}{|c|}{$\begin{array}{l}\text { This document defines the interfaces, responsibilities, and timeframes between DOE, the } \\
\text { Tank Farm Contractor, and BNFL Inc. with respect to raw water during Privatization Phase } 1 \\
\text { activities. Included is the Tank Farm Contractor responsibility to install raw water piping to } \\
\text { the Privatization Contractor fence and the amount of raw water to be delivered. }\end{array}$} \\
\hline \multicolumn{3}{|c|}{ Inter-related documents (successors and predecessors) } \\
\hline To be developed & & \\
\hline
\end{tabular}


HNF-1901 REV 2

\begin{tabular}{|l|l|l|}
\hline $\begin{array}{l}\text { Assigned Document } \\
\text { Number }\end{array}$ & Maintained Current? & Technical Baseline Subset \\
\hline D.2 & Yes & Requirements \\
\hline
\end{tabular}

Document Name

BNFL, 2000, Interface Control Document for Potable Water, BNFL-5193-ID-02, Rev. 4, as amended, BNFL Inc., Richland, Washington.

\section{Responsible Organization}

BNFL Inc., CHG, and DOE

\section{Status of Preparation/Revision}

Draft. Work is continuing on final.

\section{Source Information Designation}

Establishes interfaces with Privatization Contractor for the delivery and use of potable water.

\section{Brief Summary of Content}

This document defines the interfaces, responsibilities, and timeframes between DOE, the Tank Farm Contractor, and BNFL Inc. with respect to potable water during Privatization Phase 1 activities. Included is the Tank Farm Contractor responsibility to install potable water piping to the Privatization Contractor fence and the amount of potable water to be delivered.

Inter-related documents (successors and predecessors)

To be developed. 
HNF-1901 REV 2

\begin{tabular}{|l|l|l|}
\hline $\begin{array}{l}\text { Assigned Document } \\
\text { Number }\end{array}$ & Maintained Current? & Technical Baseline Subset \\
\hline D.3 & Yes & Requirements \\
\hline
\end{tabular}

Document Name

BNFL, 2000, Interface Control Document for Radioactive Solid Waste, BNFL-5193-ID-03, Rev. 5, as amended, BNFL Inc., Richland, Washington.

Responsible Organization

BNFL Inc., CHG, and DOE

Status of Preparation/Revision

Draft. Work is continuing on final.

Source Information Designation

Establishes interfaces with Privatization Contractor for the handling and managing of radioactive solid waste.

\section{Brief Summary of Content}

This document defines the interfaces, responsibilities, and timeframes between DOE, the Tank Farm Contractor, and the Privatization Contractor with respect to radioactive solid waste during Privatization Phase 1 activities. Included is the estimation of radioactive solid volumes and compliance with HNF-EP-0063, Hanford Site Solid Waste Acceptance Criteria (FDH 1998).

Inter-related documents (successors and predecessors)

To be developed. 
HNF-1901 REV 2

\begin{tabular}{|l|l|l|}
\hline $\begin{array}{l}\text { Assigned Document } \\
\text { Number }\end{array}$ & Maintained Current? & Technical Baseline Subset \\
\hline D.4 & Yes & Requirements \\
\hline
\end{tabular}

Document Name

BNFL, 2000, Interface Control Document for Dangerous Waste, BNFL-5193-ID-04, Rev. 3, as amended, BNFL Inc., Richland, Washington.

\section{Responsible Organization}

BNFL Inc., CHG, and DOE

\section{Status of Preparation/Revision}

Draft. Work is continuing on final.

\section{Source Information Designation}

Establishes interfaces with Privatization Contractor for dangerous waste handling.

\section{Brief Summary of Content}

This document defines the interfaces with BNFL Inc. for administrative requirements for dispositioning dangerous waste.

Inter-related documents (successors and predecessors)

To be determined. 
HNF-1901 REV 2

\begin{tabular}{|l|l|l|}
\hline $\begin{array}{l}\text { Assigned Document } \\
\text { Number }\end{array}$ & Maintained Current? & Technical Baseline Subset \\
\hline D.5 & Yes & Requirements \\
\hline
\end{tabular}

Document Name

BNFL, 2000, Interface Control Document for Nonradioactive, Nondangerous Liquid Effluents, BNFL-5193-ID-05, Rev. 4, as amended, BNFL Inc., Richland, Washington.

Responsible Organization

BNFL Inc., CHG, and DOE

\section{Status of Preparation/Revision}

Draft. Work is continuing on final.

\section{Source Information Designation}

Establishes interfaces with Privatization Contractor for the handling and managing of nonradioactive, nondangerous liquid effluents.

\section{Brief Summary of Content}

This document defines the interfaces, responsibilities, and timeframes between DOE, the Tank Farm Contractor, and the Privatization Contractor with respect to nonradioactive, nondangerous liquid effluents during Privatization Phase 1 activities. Included are the acceptance volume and flow rates from BNFL Inc., the installation and maintenance of a receiving pipeline, and regulator permit requirements.

Inter-related documents (successors and predecessors)

To be developed. 
HNF-1901 REV 2

\begin{tabular}{|l|l|l|}
\hline $\begin{array}{l}\text { Assigned Document } \\
\text { Number }\end{array}$ & Maintained Current? & Technical Baseline Subset \\
\hline D.6 & Yes & Requirements \\
\hline
\end{tabular}

\section{Document Name}

BNFL, 2000, Interface Control Document for Radioactive, Dangerous Liquid Effluents, BNFL-5193-ID-06, Rev. 4, as amended, BNFL Inc., Richland, Washington.

\section{Responsible Organization}

BNFL Inc., CHG, and DOE

\section{Status of Preparation/Revision}

Draft. Work is continuing on final.

\section{Source Information Designation}

Establishes interfaces with Privatization Contractor for the handling and managing of radioactive, dangerous liquid effluents.

\section{Brief Summary of Content}

This document defines the interfaces, responsibilities, and timeframes between DOE, the Tank Farm Contractor, and BNFL Inc. with respect to handling and managing radioactive, dangerous liquid effluents during Privatization Phase 1 activities. Included is the acceptance volume and flow rate from the Privatization Contractor, the installation and maintenance of a receiving pipeline, and regulator permitting requirements.

\section{Inter-related documents (successors and predecessors)}

To be developed. 
HNF-1901 REV 2

\begin{tabular}{|l|l|l|}
\hline $\begin{array}{l}\text { Assigned Document } \\
\text { Number }\end{array}$ & Maintained Current? & Technical Baseline Subset \\
\hline D.7 & Yes & Requirements \\
\hline
\end{tabular}

Document Name

BNFL, 2000, Interface Control Document for Nondangerous Solid Waste, BNFL-5193-ID-07, Rev. 3, as amended, BNFL Inc., Richland, Washington.

Responsible Organization

BNFL Inc., CHG, and DOE

Status of Preparation/Revision

Draft. Work is continuing on final.

\section{Source Information Designation}

Establishes interfaces with Privatization Contractor for nondangerous solid waste handling.

\section{Brief Summary of Content}

This document defines the interfaces with BNFL Inc. for administrative requirements for dispositioning nondangerous solid waste.

Inter-related documents (successors and predecessors)

To be determined. 
HNF-1901 REV 2

\begin{tabular}{|l|l|l|}
\hline $\begin{array}{l}\text { Assigned Document } \\
\text { Number }\end{array}$ & Maintained Current? & Technical Baseline Subset \\
\hline D.8 & Yes & Requirements \\
\hline
\end{tabular}

\section{Document Name}

BNFL, 2000, Interface Control Document for Liquid Sanitary Waste, BNFL-5193-ID-08, Rev. 3, as amended, BNFL Inc., Richland, Washington.

\section{Responsible Organization}

BNFL Inc., CHG, and DOE

\section{Status of Preparation/Revision}

Draft. Work is continuing on final.

\section{Source Information Designation}

Establishes interfaces with Privatization Contractor for sanitary waste handling.

\section{Brief Summary of Content}

This document defines the interfaces with BNFL Inc. for administrative requirements for dispositioning liquid sanitary waste.

Inter-related documents (successors and predecessors)

To be determined. 
HNF-1901 REV 2

\begin{tabular}{|c|c|c|}
\hline $\begin{array}{l}\text { Assigned Document } \\
\text { Number }\end{array}$ & Maintained Current? & Technical Baseline Subset \\
\hline D.9 & Yes & Requirements \\
\hline \multicolumn{3}{|c|}{$\begin{array}{l}\text { Document Name } \\
\text { BNFL, 2000, Interface Control Document for Land for Siting, BNFL-5193-ID-09, Rev.4, as } \\
\text { amended, BNFL Inc., Richland, Washington. }\end{array}$} \\
\hline \multicolumn{3}{|c|}{$\begin{array}{l}\text { Responsible Organization } \\
\text { BNFL Inc., CHG, and DOE }\end{array}$} \\
\hline \multicolumn{3}{|c|}{$\begin{array}{l}\text { Status of Preparation/Revision } \\
\text { Draft. Work is continuing on final. }\end{array}$} \\
\hline \multicolumn{3}{|c|}{$\begin{array}{l}\text { Source Information Designation } \\
\text { Establishes interfaces with Privatization Contractor for land for siting Privatization Phase } 1 .\end{array}$} \\
\hline \multicolumn{3}{|c|}{$\begin{array}{l}\text { Brief Summary of Content } \\
\text { This document defines the interfaces, responsibilities, and timeframes between DOE, the Tank } \\
\text { Farm Contractor, and BNFL Inc. with respect to land for siting Privatization Phase } 1 \text { activities. } \\
\text { Included are the land location and size and a no-cost lease. }\end{array}$} \\
\hline \multicolumn{3}{|c|}{ Inter-related documents (successors and predecessors) } \\
\hline
\end{tabular}


HNF-1901 REV 2

\begin{tabular}{|l|l|l|}
\hline $\begin{array}{l}\text { Assigned Document } \\
\text { Number }\end{array}$ & Maintained Current? & Technical Baseline Subset \\
\hline D.10 & Yes & Requirements \\
\hline Document Name & BNFL, 2000, Interface Control Document for Deactivated Facility and Site, \\
BNFL-5193-ID-10, Rev. 3, as amended, BNFL Inc., Richland, Washington. \\
\hline Responsible Organization \\
BNFL Inc., CHG, and DOE \\
Status of Preparation/Revision \\
Draft. Work is continuing on final. \\
\hline Source Information Designation \\
Establishes interfaces with Privatization Contractor for facility deactivation and site turnover to \\
DOE following completion of Privatization Phase 1 activities. \\
\hline Brief Summary of Content \\
This document defines the interfaces, responsibilities, and timeframes between DOE, the Tank \\
Farm Contractor, and BNFL Inc. with respect to facility deactivation and site turnover to DOE \\
following completion of Privatization Phase 1 activities. \\
\hline $\begin{array}{l}\text { Inter-related documents (successors and predecessors) } \\
\text { To be developed. }\end{array}$ \\
\hline
\end{tabular}


HNF-1901 REV 2

\begin{tabular}{|l|l|l|}
\hline $\begin{array}{l}\text { Assigned Document } \\
\text { Number }\end{array}$ & Maintained Current? & Technical Baseline Subset \\
\hline D.11 & Yes & Requirements \\
\hline
\end{tabular}

\section{Document Name}

BNFL, 2000, Interface Control Document for Electricity, BNFL-5193-ID-11, Rev. 4, as amended, BNFL Inc., Richland, Washington.

\section{Responsible Organization}

BNFL Inc., CHG, and DOE

\section{Status of Preparation/Revision}

Draft. Work is continuing on final.

\section{Source Information Designation}

Establishes interfaces with Privatization Contractor with respect to electricity delivery to Privatization Contractor facilities during Privatization Phase 1 activities.

\section{Brief Summary of Content}

This document defines the interfaces, responsibilities, and timeframes between DOE, the Tank Farm Contractor, and BNFL Inc. with respect to electricity delivery during Privatization Phase 1. Included is the defined power supply and capacity. DynCorp Tri-Cities Services, Incorporated, will supply the power.

Inter-related documents (successors and predecessors)

To be developed. 
HNF-1901 REV 2

\begin{tabular}{|c|c|c|}
\hline $\begin{array}{l}\text { Assigned Document } \\
\text { Number }\end{array}$ & Maintained Current? & Technical Baseline Subset \\
\hline D. 12 & Yes & Requirements \\
\hline \multicolumn{3}{|c|}{$\begin{array}{l}\text { Document Name } \\
\text { BNFL, 2000, Interface Control Document for Roads, BNFL-5193-ID-12, as amended, Rev. 4, } \\
\text { BNFL Inc., Richland, Washington. }\end{array}$} \\
\hline \multicolumn{3}{|c|}{$\begin{array}{l}\text { Responsible Organization } \\
\text { BNFL Inc., CHG, and DOE }\end{array}$} \\
\hline \multicolumn{3}{|c|}{$\begin{array}{l}\text { Status of Preparation/Revision } \\
\text { Draft. Work is continuing on final. }\end{array}$} \\
\hline \multicolumn{3}{|c|}{$\begin{array}{l}\text { Establishes interfaces with Privatization Contractor for road use during Privatization Phase } 1 \\
\text { activities and establishes that there will be no direct rail. }\end{array}$} \\
\hline \multicolumn{3}{|c|}{$\begin{array}{l}\text { This document defines the interfaces, responsibilities, and timeframes between DOE, the Tank } \\
\text { Farm Contractor, and BNFL Inc. with respect to road and rail construction and uses during } \\
\text { Privatization Phase } 1 \text { activities. Included is the government responsibility to supply roads to the } \\
\text { boundary and that the Privatization Contractor will build and maintain roads within the boundary. } \\
\text { No direct rail line will be provided. }\end{array}$} \\
\hline $\begin{array}{l}\text { Inter-related docum } \\
\text { To be developed. }\end{array}$ & essors and predecessors & \\
\hline
\end{tabular}


HNF-1901 REV 2

\begin{tabular}{|l|l|l|}
\hline $\begin{array}{l}\text { Assigned Document } \\
\text { Number }\end{array}$ & Maintained Current? & Technical Baseline Subset \\
\hline D.13 & Yes & Requirements \\
\hline
\end{tabular}

\section{Document Name}

BNFL, 2000, Interface Control Document for Immobilized High-Level Waste, BNFL-5193-ID-14, Rev. 4, as amended, Draft, BNFL Inc., Richland, Washington.

Responsible Organization

CHG

Status of Preparation/Revision

Draft. Work is continuing on final.

Source Information Designation

Establishes interfaces with Privatization Contractor for the acceptance and delivery of immobilized high-level waste product by and to DOE and the Tank Farm Contractor during Privatization Phase 1 activities.

\section{Brief Summary of Content}

This document defines the interfaces, responsibilities, and timeframes between DOE, the Tank Farm Contractor, and BNFL Inc. with respect to the acceptance and delivery of the immobilized high-level waste product by and to DOE and the Tank Farm Contractor during Privatization Phase 1 activities. Included are packaging and acceptance criteria and notification requirements.

Inter-related documents (successors and predecessors)

To be developed. 
HNF-1901 REV 2

\begin{tabular}{|l|l|l|}
\hline $\begin{array}{l}\text { Assigned Document } \\
\text { Number }\end{array}$ & Maintained Current? & Technical Baseline Subset \\
\hline D.14 & Yes & Requirements \\
\hline
\end{tabular}

Document Name

BNFL, 2000, Interface Control Document for Immobilized Low-Activity Waste, BNFL-5193-ID-15, Rev. 4, as amended, Draft, BNFL Inc., Richland, Washington.

\section{Responsible Organization}

BNFL Inc., CHG, and DOE

\section{Status of Preparation/Revision}

Draft. Work is continuing on final.

\section{Source Information Designation}

Establishes interfaces with Privatization Contractor for acceptance and delivery of the immobilized low-activity waste product by and to DOE and the Tank Farm Contractor during Privatization Phase 1 activities.

\section{Brief Summary of Content}

This document defines the interfaces, responsibilities, and timeframes between DOE, the Tank Farm Contractor, and BNFL Inc. with respect to acceptance and delivery of immobilized low-activity waste product by and to DOE and the Tank Farm Contractor during Privatization Phase 1 activities. Included are packaging and acceptance criteria and notification requirements.

Inter-related documents (successors and predecessors)

To be developed. 
HNF-1901 REV 2

\begin{tabular}{|l|l|l|}
\hline $\begin{array}{l}\text { Assigned Document } \\
\text { Number }\end{array}$ & Maintained Current? & Technical Baseline Subset \\
\hline D.15 & Yes & Requirements \\
\hline
\end{tabular}

Document Name

BNFL, 2000, Interface Control Document for Entrained Solids, BNFL-5193-ID-16, Rev. 3, BNFL Inc., Richland, Washington.

\section{Responsible Organization}

BNFL Inc., CHG, and DOE

\section{Status of Preparation/Revision}

Draft. Work is continuing on final.

\section{Source Information Designation}

Establishes interfaces with Privatization Contractor for the return of entrained solids to DOE and the Tank Farm Contractor from the Privatization Contractor during Privatization Phase 1 activities.

\section{Brief Summary of Content}

This document defines the interfaces, responsibilities, and timeframes between DOE, the Tank Farm Contractor, and BNFL Inc. with respect to the return of entrained solids to DOE and the Tank Farm Contractor from the Privatization Contractor during Privatization Phase 1 activities. Included are transfer-mechanism (pipeline) information and lag-storage requirements.

Inter-related documents (successors and predecessors)

To be developed. 
HNF-1901 REV 2

\begin{tabular}{|l|l|l|}
\hline $\begin{array}{l}\text { Assigned Document } \\
\text { Number }\end{array}$ & Maintained Current? & Technical Baseline Subset \\
\hline D.16 & Yes & Requirements \\
\hline
\end{tabular}

\section{Document Name}

BNFL, 2000, Interface Control Document for Low-Activity Waste Feed, BNFL-5193-ID-19, Rev. 4, as amended, BNFL Inc., Richland, Washington.

\section{Responsible Organization}

BNFL Inc., CHG, and DOE

Status of Preparation/Revision

Draft. Work is continuing on final.

Source Information Designation

Establishes interfaces with Privatization Contractor for the delivery of low-activity waste feed.

\section{Brief Summary of Content}

This document defines the interfaces, responsibilities, and timeframes between DOE, the Tank Farm Contractor, and BNFL Inc, with respect to the delivery of low-activity waste feed to the Privatization Contractor during Privatization Phase 1 activities. Included is the selection of waste envelopes and waste quantity, provision of waste feed composition, and provision of samples to the Privatization Contractor for testing.

Inter-related documents (successors and predecessors)

To be developed. 
HNF-1901 REV 2

\begin{tabular}{|l|l|l|}
\hline $\begin{array}{l}\text { Assigned Document } \\
\text { Number }\end{array}$ & Maintained Current? & Technical Baseline Subset \\
\hline D.17 & Yes & Requirements \\
\hline
\end{tabular}

\section{Document Name}

BNFL, 2000, Interface Control Document for High-Level Waste Feed, BNFL-5193-ID-20, Rev. 4, as amended, BNFL Inc., Richland, Washington.

\section{Responsible Organization}

BNFL Inc., CHG, and DOE

\section{Status of Preparation/Revision}

Draft. Work is continuing on final.

\section{Source Information Designation}

Establishes interfaces with Privatization Contractor for the delivery of high-activity waste feed.

\section{Brief Summary of Content}

This document defines the interfaces, responsibilities, and timeframes between DOE, the Tank Farm Contractor, and BNFL Inc. with respect to the delivery of high-level waste feed to the Privatization Contractor during Privatization Phase 1 activities. Included is the transfer of HLW feed consistent with specifications, and provision of samples to the Privatization Contractor for testing.

Inter-related documents (successors and predecessors)

To be developed. 
HNF-1901 REV 2

\begin{tabular}{|l|l|l|}
\hline $\begin{array}{l}\text { Assigned Document } \\
\text { Number }\end{array}$ & Maintained Current? & Technical Baseline Subset \\
\hline D.18 & Yes & Requirements \\
\hline
\end{tabular}

\section{Document Name}

BNFL, 2000, Interface Control Document for Air Emissions, BNFL-5193-ID-22, Rev. 3, as amended, BNFL Inc., Richland, Washington.

\section{Responsible Organization}

BNFL Inc., CHG, and DOE

\section{Status of Preparation/Revision}

Draft. Work is continuing on final.

\section{Source Information Designation}

Establishes interfaces with Privatization Contractor with respect to air emissions from the Privatization Contractor's facilities.

\section{Brief Summary of Content}

This document defines the interfaces and responsibilities for air emissions regulatory and reporting requirements. DOE and Tank Farm Contractor responsibilities include reviewing and concurring with notices of construction, seeking modifications to the Hanford Air Operating Permit, allocating emissions, and using the existing monitoring network to collect required air samples.

Inter-related documents (successors and predecessors)

To be developed. 
HNF-1901 REV 2

\begin{tabular}{|l|l|l|}
\hline $\begin{array}{l}\text { Assigned Document } \\
\text { Number }\end{array}$ & Maintained Current? & Technical Baseline Subset \\
\hline D.19 & Yes & Requirements \\
\hline
\end{tabular}

\section{Document Name}

BNFL, 2000, Interface Control Document for Waste Treatability Samples, BNFL-5193-ID-23, Rev. 3, as amended, BNFL Inc., Richland, Washington.

\section{Responsible Organization}

BNFL Inc., CHG, and DOE

\section{Status of Preparation/Revision}

Draft. Work is continuing on final.

\section{Source Information Designation}

Establishes interfaces with Privatization Contractor for waste treatability sample delivery and residue return.

\section{Brief Summary of Content}

This document defines the interfaces and responsibilities for waste treatability samples that will be used by the Privatization Contractor to develop information in support of facility design, safety basis, and permitting. DOE and the Tank Farm Contractor are responsible for obtaining the samples and providing them to the Privatization Contractor and for dispositioning the returned residue from studies conducted on these samples.

Inter-related documents (successors and predecessors)

To be developed. 
HNF-1901 REV 2

\begin{tabular}{|l|l|l|}
\hline $\begin{array}{l}\text { Assigned Document } \\
\text { Number }\end{array}$ & Maintained Current? & Technical Baseline Subset \\
\hline D.20 & Yes & Requirements \\
\hline
\end{tabular}

Document Name

BNFL, 2000, Interface Control Document for Emergency Response, BNFL-5193-ID-25,

Rev. 3, as amended, BNFL Inc., Richland, Washington.

\section{Responsible Organization}

BNFL Inc., CHG, and DOE

\section{Status of Preparation/Revision}

Draft. Work is continuing on final.

Source Information Designation

Establishes interfaces with Privatization Contractor for emergency response to events involving the Privatization Contractor facilities and the Hanford Site.

\section{Brief Summary of Content}

This document defines the interfaces and responsibilities for emergency planning notification, preparedness, response, and reporting. The interface covers organization, authorities, and responsibilities for BNFL Inc. and DOE.

Inter-related documents (successors and predecessors)

To be developed. 
HNF-1901 REV 2

\begin{tabular}{|l|l|l|}
\hline $\begin{array}{l}\text { Assigned Document } \\
\text { Number }\end{array}$ & Maintained Current? & Technical Baseline Subset \\
\hline D.21 & Yes & Requirements \\
\hline
\end{tabular}

\section{Document Name}

BNFL, 2000, Interface Control Document for Permitting, BNFL-5193-ID-26, Rev. 3, as amended, BNFL Inc., Richland, Washington.

\section{Responsible Organization}

BNFL Inc., CHG, and DOE

\section{Status of Preparation/Revision}

Draft. Work is continuing on final.

\section{Source Information Designation}

Establishes interfaces with Privatization Contractor for permits.

\section{Brief Summary of Content}

This document defines the interfaces with BNFL Inc. for administrative requirements for permitting and compliance. DOE and the Tank Farm Contractor have the responsibility to review and comment on treatment-facility permit applications and provide Site information for use in permit applications, permit modifications, and requested modifications to Hanford Site permits to incorporate Privatization Contractor activities.

Inter-related documents (successors and predecessors)

To be developed. 
HNF-1901 REV 2

This page intentionally left blank. 
HNF-1901 REV 2

\section{APPENDIX E}

PRODUCT STORAGE AND DISPOSAL DOCUMENTS

E-i 


\section{HNF-1901 REV 2}

This page intentionally left blank.

E-ii 
HNF-1901 REV 2

\begin{tabular}{|l|l|l|}
\hline $\begin{array}{l}\text { Assigned Document } \\
\text { Number }\end{array}$ & Maintained Current? & Technical Baseline Subset \\
\hline E.1 & Yes & Requirements \\
\hline
\end{tabular}

Document Name

Alm, A. L., 1996, "Approval of Critical Decisions for Phase 1 Immobilized High-Level and Low-Activity Waste Interim Storage and Tank Farm Restoration and Safe Operations Projects (Projects W-464, W-465, and W-314)," (letter to J. Wagoner, Manager, U.S. Department of Energy, Richland Operations Office, Richland, Washington, December 26), U.S. Department of Energy, Washington, D.C.

Responsible Organization

DOE-RL

Status of Preparation/Revision

The U.S. Department of Energy memo was issued December 26, 1996.

Source Information Designation

Identification of immobilized wastes to be stored.

Brief Summary of Content

U.S. Department of Energy decision document authorizing start of conceptual design for highlevel waste and low-activity waste interim storage.

Inter-related documents (successors and predecessors)

None. 
HNF-1901 REV 2

\begin{tabular}{|l|l|l|}
\hline $\begin{array}{l}\text { Assigned Document } \\
\text { Number }\end{array}$ & Maintained Current? & Technical Baseline Subset \\
\hline E.2 & Yes & Requirements \\
\hline
\end{tabular}

\section{Document Name}

Calmus, R. B., 1996b, HLW Interim Storage Architecture Selection - Decision Report, WHC-SD-WM-TA-183, Rev. 0, Westinghouse Hanford Company, Richland, Washington.

Responsible Organization

CHG

Status of Preparation/Revision

The most recent full revision is included with the document name. Partial revisions are indicated by the notation, "as amended." The document will be revised as needed.

\section{Source Information Designation}

Establishes disposal options and facilities for immobilized high-level waste.

\section{Brief Summary of Content}

The U.S. Department of Energy has embarked upon a course to acquire Hanford Site tank waste treatment and immobilization services using privatized facilities. This plan contains a two-phase approach. Phase 1 is a "proof of principle/commercial demonstration-scale" effort and Phase 2 is a full-scale production effort. Interim storage and disposal of various products from privatized facilities are not included in the privatization scope. Interim storage capabilities are to be furnished by the U.S. Department of Energy. This document presents the decision and decision basis to provide for interim storage of Phase 1 high-level waste products until they can be transferred to a Federal geologic repository for disposal.

Inter-related documents (successors and predecessors)

None. 
HNF-1901 REV 2

\begin{tabular}{|l|l|l|}
\hline $\begin{array}{l}\text { Assigned Document } \\
\text { Number }\end{array}$ & Maintained Current? & Technical Baseline Subset \\
\hline E.3 & No & Requirements \\
\hline
\end{tabular}

\section{Document Name}

Claghorn, R. D., 1997, Decision Document for the Final Disposition of Cesium and Strontium Capsules, HNF-SD-WM-RPT-294, Rev. 0, Numatec Hanford Corporation for Fluor Daniel Hanford, Inc., Richland, Washington.

\section{Responsible Organization}

\section{CHG}

\section{Status of Preparation/Revision}

The most recent full revision is included with the document name. Partial revisions are indicated by the notation, "as amended." The document will be revised as needed.

\section{Source Information Designation}

Discusses how and when cesium-137/strontium-90 capsules at the Hanford Site will be prepared for disposal.

\section{Brief Summary of Content}

This report was prepared to document decisions regarding the disposition of cesium and strontium capsules. A decision support board was established to consider the multiple drivers for decisions regarding disposition of cesium and strontium capsules and to make the decisions that forms the near-term guidance for the project. The decision process included several decision board meetings, documented in this report, in which technical and programmatic information was presented by technical staff and considered by the decision board. The process also included preparation of the decision documentation, which is presented in this report.

\section{Inter-related documents (successors and predecessors)}

Taylor, W. J., 1998, “Contract No. DE-AC06-96RL13200 - Waste Disposal Division (WDD) Multi-Year Work Plan (MYWP) Update Guidance for Fiscal Year 1999 (FY99)," (letter 98-WDD-103 to R. D. Hanson, Fluor Daniel Hanford, Inc., September 21), U.S. Department of Energy, Richland Operations Office, Richland, Washington. 
HNF-1901 REV 2

\begin{tabular}{|c|c|c|}
\hline $\begin{array}{l}\text { Assigned Document } \\
\text { Number }\end{array}$ & Maintained Current? & Technical Baseline Subset \\
\hline E.4 & No & (See individual list below) \\
\hline \multicolumn{3}{|c|}{$\begin{array}{l}\text { Document Identification } \\
\text { Technical baseline documents for Project W-464 }\end{array}$} \\
\hline \multicolumn{3}{|l|}{ CHG } \\
\hline \multicolumn{3}{|c|}{ Status of Preparation/Revision } \\
\hline \multicolumn{3}{|c|}{$\begin{array}{l}\text { Source Information Designation } \\
\text { Technical baseline documents related to the W-464 Project. }\end{array}$} \\
\hline \multicolumn{3}{|c|}{$\begin{array}{l}\text { The project technical baseline documents are divided into } 19 \text { categories as identified below. } \\
\text { The categories were developed in accordance with applicable engineering plans and procedures }\end{array}$} \\
\hline \multicolumn{3}{|c|}{ 1. Functional Design Criteria (Requirements) } \\
\hline \multicolumn{3}{|c|}{$\begin{array}{l}\text { Calmus, R. B., 1996a, Design Requirements Document for Interim Store Phase I Solidified } \\
\text { High-Level Waste, Function 4.2.4.1.2, WHC-SD-WM-DRD-012, Rev. 0, Westinghouse } \\
\text { Hanford Company, Richland, Washington. }\end{array}$} \\
\hline \multicolumn{3}{|c|}{ 2. Conceptual Design Report } \\
\hline \multicolumn{3}{|l|}{ TBD } \\
\hline \multicolumn{3}{|c|}{ 3. Final Design Review Report } \\
\hline \multicolumn{3}{|l|}{ TBD } \\
\hline \multicolumn{3}{|c|}{ 4. Alternative Design Study } \\
\hline \multicolumn{3}{|l|}{ TBD } \\
\hline \multicolumn{3}{|c|}{ 5. Acceptance Test Plan reports (projects only) } \\
\hline TBD & & \\
\hline
\end{tabular}


6. Operational Test Plan

TBD

7. Operational Readiness Review/Acceptance Beneficial Use

TBD

8. Calculation/Analysis

TBD

9. Supporting Documents (Requirements)

Deffenbaugh, M. L., 1996, "Environmental Requirements Checklist for the High-Level Waste Storage Project Canister Storage Building," (letter 70100-96-004 to K. C. Burgard, November 4), Lockheed Martin Hanford Corporation, Richland, Washington.

Deffenbaugh, M. L., J. D. Guberski, C. J. Grando, V. L. Armstrong, J. E. Mercado, and M. W. Cline, 1997, Permitting Plan for the Immobilized Low-Activity Waste Project, HNF-SD-ENV-EE-003, Rev. 0, Lockheed Martin Hanford Corporation for Fluor Daniel Hanford, Inc., Richland Washington.

Jacobs, E. R., 1996, Final CSB High-Level Waste Supplemental Report, (letter FRF049 to J. J. Jones, Westinghouse Hanford Company, September 19), Fluor Daniel, Inc., Richland, Washington.

10. PSAR and Authorization Basis

TBD

11. Reliability, Availability, Maintainability (RAM) Analysis

TBD

12. Constructability, Operability, and Implementability Analysis

TBD

13. Vendor Drawings/Instruction Manuals

TBD

14. System Design Description

TBD 
15. Spare Parts List

TBD

16. Control Drawings

TBD

17. Safety Equipment List

TBD

18. Construction Specifications

TBD

19. Fabrication Specifications

TBD

Inter-related documents (successors and predecessors)

To be developed. 
HNF-1901 REV 2

\begin{tabular}{|c|c|c|}
\hline $\begin{array}{l}\text { Assigned Document } \\
\text { Number }\end{array}$ & Maintained Current? & Technical Baseline Subset \\
\hline E.5 & Yes & (See individual list below) \\
\hline \multicolumn{3}{|c|}{$\begin{array}{l}\text { Document Identification } \\
\text { Technical baseline documents for Project W-520 }\end{array}$} \\
\hline \multicolumn{3}{|c|}{$\begin{array}{l}\text { Responsible Organization } \\
\text { CHG }\end{array}$} \\
\hline \multicolumn{3}{|c|}{$\begin{array}{l}\text { Status of Preparation/Revision } \\
\text { Various }\end{array}$} \\
\hline \multicolumn{3}{|c|}{$\begin{array}{l}\text { Source Information Designation } \\
\text { Technical baseline documents related to the W-520 Project, Immobilized Low-Activity Waste } \\
\text { Interim Storage. Note: This project replaces W-465. }\end{array}$} \\
\hline \multicolumn{3}{|c|}{$\begin{array}{l}\text { Brief Summary of Content } \\
\text { The project technical baseline documents are divided int } \\
\text { The categories were developed in accordance with appli } \\
\text { 1. Functional Design Criteria (Requirements) }\end{array}$} \\
\hline \multicolumn{3}{|c|}{$\begin{array}{l}\text { Ashworth, S. C., and D. A. Burbank, 1998, Design Requirements Document for Project W-520, } \\
\text { Immobilized Low-Activity Waste Disposal, HNF-2211, Rev. 0, COGEMA Engineering Corp., } \\
\text { Richland, Washington. }\end{array}$} \\
\hline \multicolumn{3}{|l|}{ TBD } \\
\hline \multicolumn{3}{|c|}{ 3. Alternative Design Study } \\
\hline \multicolumn{3}{|l|}{ TBD } \\
\hline \multicolumn{3}{|c|}{ 4. Final Design Review Report } \\
\hline
\end{tabular}


5. Acceptance Test Plan

TBD

6. Operational Test Plan

TBD

7. Operational Readiness Review/Acceptance Beneficial Use

TBD

8. Calculation/Analysis

TBD

9. Supporting Documents

TBD

10. PSAR Authorization Basis

TBD

11. Reliability, Availability, Maintainability (RAM) Analysis

TBD

12. Constructability, Operability, and Implementability Analysis

TBD

13. Vendor Drawings/Instruction Manuals

TBD

14. System Design Description

TBD

15. Spare Parts List

TBD

16. Control Drawings

TBD 
17. Safety Equipment List

TBD

18. Construction Specifications

TBD

19. Fabrication Specifications

TBD

Inter-related documents (successors and predecessors)

To be developed. 
HNF-1901 REV 2

\begin{tabular}{|l|l|l|}
\hline $\begin{array}{l}\text { Assigned Document } \\
\text { Number }\end{array}$ & Maintained Current? & Technical Baseline Subset \\
\hline E.6 & No & Design \\
\hline
\end{tabular}

\section{Document Name}

Shade, J. W., C. T. Kincaid, G. A. Whyatt, M. G. Piepho, K. Rhoads, J. A. Voogd, J. H.

Westsik, M. D. Freshley, 1994, Performance Assessment of Grouted Double-Shell Tank Waste

Disposal at Hanford, WHC-SD-WM-EE-004, Rev. 1, Westinghouse Hanford Company, Richland, Washington.

\section{Responsible Organization}

\section{CHG}

\section{Status of Preparation/Revision}

The most recent full revision is included with the document name. Partial revisions are indicated by the notation, "as amended." The document will be revised as needed.

\section{Source Information Designation}

Discusses relationship of immobilized low-activity waste to ongoing performance assessments and confirms that existing grout vaults are sufficient for the first four years of operation.

\section{Brief Summary of Content}

This document provides the performance assessment required for the Grout Disposal Facility. It provides a technical analysis of potential impacts to the public from the release of waste radionuclides disposed of in grout. This analysis includes an evaluation of disposal-system properties, environmental conditions, and public-exposure scenarios. These potential future conditions are analyzed for time periods extending up to 10,000 years for comparison to the performance objectives. Analyses beyond 10,000 years are conducted to evaluate potential maximum impact. Although future events cannot be predicted with certainty, the range of scenarios presented in this performance assessment provides some understanding of the critical elements influencing public exposure from waste disposal.

Inter-related documents (successors and predecessors)

None. 
HNF-1901 REV 2

\begin{tabular}{|l|l|l|}
\hline $\begin{array}{l}\text { Assigned Document } \\
\text { Number }\end{array}$ & Maintained Current? & Technical Baseline Subset \\
\hline E.7 & No & Design \\
\hline
\end{tabular}

Document Name

Mann, F. M., C. R. Eiholzer, Y. Chen, N. W. Kline, A. H. Lu, B. P. McGrail, and P. D. Rittmann, 1997, Hanford Low-Level Tank Waste Interim Performance Assessment, HNF-EP-0884, Rev. 1, Fluor Daniel Hanford, Inc., Richland, Washington.

Responsible Organization

CHG.

\section{Status of Preparation/Revision}

The most recent full revision is included with the document name. Partial revisions are indicated by the notation, "as amended." The document will be revised as needed.

\section{Source Information Designation}

Examines long-term health and environmental effects associated with disposal in the Hanford Site 200 East Area of low-activity waste from single-shell tanks and double-shell tanks.

\section{Brief Summary of Content}

This report examines the long-term environmental and human-health effects associated with the disposal of the low-level fraction of the single- and double-shell tank waste in the Hanford Site 200 East Area. This report was prepared as a good management practice to provide needed information about the relationship between the disposal-system design and performance early in the disposal-system project cycle. The calculations in this performance assessment show that the disposal of the low-level fraction can meet environmental and health performance objectives.

Inter-related documents (successors and predecessors)

None. 
HNF-1901 REV 2

\begin{tabular}{|l|l|l|}
\hline $\begin{array}{l}\text { Assigned Document } \\
\text { Number }\end{array}$ & Maintained Current? & Technical Baseline Subset \\
\hline E.8 & Yes & Requirements \\
\hline
\end{tabular}

Document Name

Deffenbaugh, M. L., J. D. Guberski, C. J. Grando, V. L. Armstrong, J. E. Mercado, and M. W. Cline, 1997, Permitting Plan for the Immobilized Low-Activity Waste Project, HNF-SD-ENV-EE-003, Rev. 0, Lockheed Martin Hanford Corporation for Fluor Daniel Hanford, Inc., Richland Washington.

Responsible Organization

CHG

Status of Preparation/Revision

The most recent full revision is included with the document name. Partial revisions are indicated by the notation, "as amended." The document will be revised as needed.

\section{Source Information Designation}

Establishes requirements, alternatives, implementation strategy, and estimated costs for environmental permits and compliance.

\section{Brief Summary of Content}

This document addresses the environmental permitting requirements for the transportation and interim storage of the immobilized low-activity waste produced during Hanford Site Privatization Phase 1.

Inter-related documents (successors and predecessors)

None. 
HNF-1901 REV 2

\begin{tabular}{|l|l|l|}
\hline $\begin{array}{l}\text { Assigned Document } \\
\text { Number }\end{array}$ & Maintained Current? & Technical Baseline Subset \\
\hline E.9 & Yes & Requirements \\
\hline
\end{tabular}

Document Name

Deffenbaugh, M. L., 1996, "Environmental Requirements Checklist for the High-Level Waste Storage Project Canister Storage Building," (letter 70100-96-004 to K. C. Burgard, November 4), Lockheed Martin Hanford Corporation, Richland, Washington.

\section{Responsible Organization}

CHG

\section{Status of Preparation/Revision}

The document was issued via letter in November 1996.

\section{Source Information Designation}

Establishes requirements, alternatives, implementation strategy, and estimated costs for environmental permits and compliance.

\section{Brief Summary of Content}

The path forward for solidified high-level waste (HLW) interim storage entails use of the spent nuclear fuel Canister Storage Building (CSB) for interim storage of solidified HLW produced during Privatization Phase 1. The CSB is designed as a "zero discharge" facility. Engineering assessments have indicated that excess CSB vaults (the two southern-most vaults 2 and 3 ) could, with some modification, be used for immobilized HLW interim storage. This environmental checklist addresses the specific storage of Phase $1 \mathrm{HLW}$ products in the CSB. This permitting checklist will provide the basis to develop a permitting plan concurrent with HLW interim-storage project CSB conceptual design.

Inter-related documents (successors and predecessors)

None. 
HNF-1901 REV 2

\begin{tabular}{|l|l|l|}
\hline $\begin{array}{l}\text { Assigned Document } \\
\text { Number }\end{array}$ & Maintained Current? & Technical Baseline Subset \\
\hline E.10 & Yes & Requirements \\
\hline
\end{tabular}

\section{Document Name}

Deffenbaugh, M. L., 1998, Environmental Permits and Approvals Plan for High-Level Waste Interim Storage, Project W-464, HNF-SD-ENV-EE-002, Rev. 1, Lockheed Martin Hanford Corporation for Fluor Daniel Hanford, Inc., Richland, Washington.

\section{Responsible Organization}

\section{CHG}

\section{Status of Preparation/Revision}

The most recent full revision is included with the document name. Partial revisions are indicated by the notation, "as amended." The document will be revised as needed.

\section{Source Information Designation}

Establishes requirements, alternatives, implementation strategy, and estimated costs for environmental permits and compliance.

\section{Brief Summary of Content}

This permitting and approvals plan describes the environmental permitting activities necessary for the transportation and interim storage of (1) immobilized high-level waste (IHLW), produced primarily during Phase 1 vitrification plant operations (glass product), (2) radioactive cesium, separated during Phase 1 low-activity waste (LAW) vitrification plant operation (separated cesium), and (3) secondary high-level radioactive and mixed waste, produced during Phase 1 (high-level waste [HLW] and LAW vitrification plant operations (nonroutine HLW). Secondary or nonroutine HLW is expected to consist primarily of refractory and solidified glass from failed melters.

This plan has several objectives, including the following:

- Identification of the necessary permitting activities

- Evaluation of the current permitting status for IHLW activities

- Identification of options and strategies to comply with environmental requirements

- Recommended course of action for each of the required permitting activities

- Estimated time required to undertake those permitting activities

- Estimated cost to implement the permitting activities.

Inter-related documents (successors and predecessors)

None. 
HNF-1901 REV 2

APPENDIX F

\section{SAFE STORAGE DOCUMENTS}

F-i 
HNF-1901 REV 2

This page intentionally left blank.

F-ii 
HNF-1901 REV 2

APPENDIX F

SAFE STORAGE DOCUMENTS

\begin{tabular}{|l|l|l|}
\hline $\begin{array}{l}\text { Assigned Document } \\
\text { Number }\end{array}$ & Maintained Current? & Technical Baseline Subset \\
\hline F.1 & Yes & Design \\
\hline Document Name \\
$\begin{array}{l}\text { Domnoske-Rauch, L. A., 2000, Tank Farms Essential Drawing Plan, HNF-SD-WM-PC-002, } \\
\text { Rev. 12, CH2M HILL Hanford Group, Inc., Richland, Washington. }\end{array}$ \\
\hline Responsible Organization \\
CHG \\
\hline $\begin{array}{l}\text { Status of Preparation/Revision } \\
\text { The most recent full revision is included with the document name. Partial revisions are } \\
\text { indicated by the notation, "as amended." The document will be revised as needed. }\end{array}$ \\
\hline $\begin{array}{l}\text { Source Information Designation } \\
\text { Drawing baseline of tank farm operations. }\end{array}$ \\
\hline $\begin{array}{l}\text { Brief Summary of Content } \\
\text { This document provides a detailed listing of essential and support drawings selected for the } \\
\text { tank farms and associated facilities. While planned for maintaining current, scope and budget } \\
\text { guidance has limited revision. }\end{array}$ \\
$\begin{array}{l}\text { Inter-related documents (successors and predecessors) } \\
\text { To be determined. }\end{array}$ \\
\hline
\end{tabular}


HNF-1901 REV 2

\begin{tabular}{|l|l|l|}
\hline $\begin{array}{l}\text { Assigned Document } \\
\text { Number }\end{array}$ & Maintained Current? & Technical Baseline Subset \\
\hline F.2 & Yes & Operations \\
\hline
\end{tabular}

Document Name

Coleman, L., J. Colgan, W. Cox, B. Crea, P. Powell, and R. Webb, 1997, Tank Farms

Operations Administrative Controls, HNF-IP-1266, Rev. 1, as amended, Lockheed Martin Hanford Corporation for Fluor Daniel Hanford, Inc.

This document is revised uniquely in that certain sections have revision numbers yet the document has no overall revision. It is available on the internet at http://aptfpg02.rl.gov/1266_Procedures/1266.htm.

\section{Responsible Organization}

CHG

\section{Status of Preparation/Revision}

The most recent full revision is included with the document name. Partial revisions are indicated by the notation, "as amended." The document will be revised as needed.

\section{Source Information Designation}

Authorization Basis implementing document.

\section{Brief Summary of Content}

This document provides operational control requirements and steps for implementing the technical safety requirement administrative controls.

Inter-related documents (successors and predecessors)

Tank Waste Remediation System Technical Safety Requirements (CHG 2000b) 
HNF-1901 REV 2

\begin{tabular}{|l|l|l|}
\hline $\begin{array}{l}\text { Assigned Document } \\
\text { Number }\end{array}$ & Maintained Current? & Technical Baseline Subset \\
\hline F.3 & Yes & Operations \\
\hline
\end{tabular}

\section{Document Name}

Zaman, S. H., 1999, TWRS Facility Safety Equipment List, HNF-SD-WM-SEL-040, Rev. 4, as amended, Lockheed Martin Hanford Corporation, Richland, Washington.

The master equipment list is maintained in the $\mathrm{CHG}$ job control system database.

\section{Responsible Organization}

CHG

\section{Status of Preparation/Revision}

The most recent full revision is included with the document name. Partial revisions are indicated by the notation, "as amended." The document will be revised as needed.

\section{Source Information Designation}

Component identification document.

\section{Brief Summary of Content}

This equipment list provides a component designation for tank farm SSCs.

Inter-related documents (successors and predecessors)

To be determined 
HNF-1901 REV 2

This page intentionally left blank.

F-4 
HNF-1901 REV 2

\section{APPENDIX G}

\section{REFERENCES}

G-i 
HNF-1901 REV 2

This page intentionally left blank.

\section{G-ii}




\section{CONTENTS}

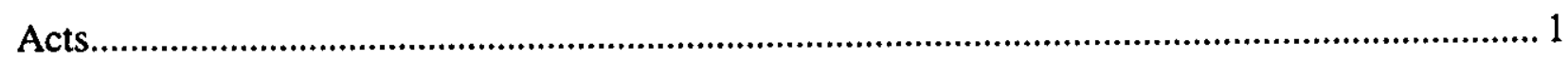

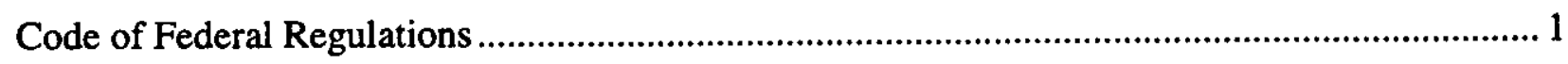

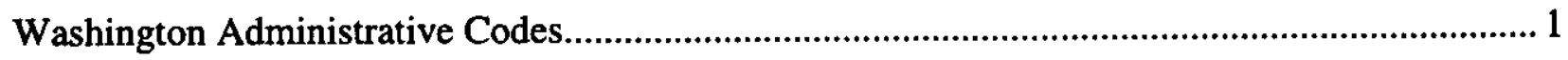

U.S. Department of Energy Directives...................................................................................... 1

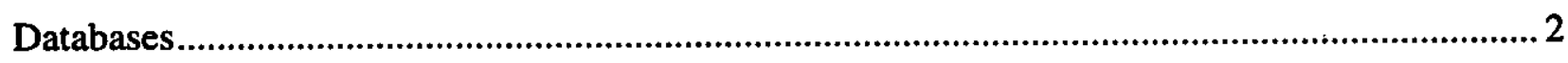

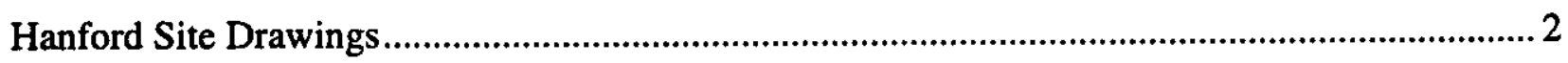

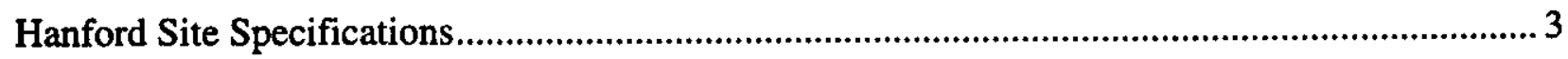

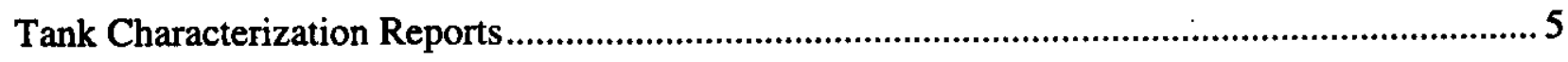

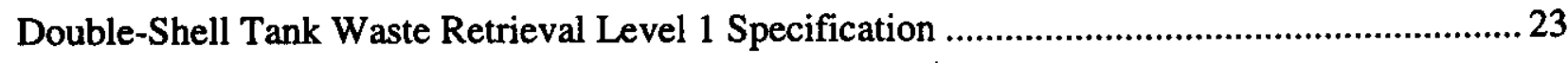

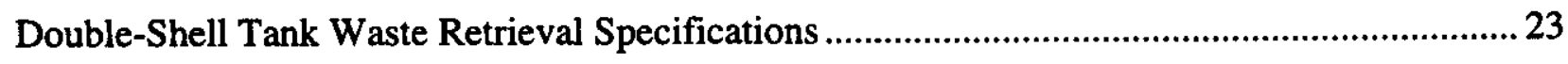

Interface Control Documents between BNFL Inc. and U.S. Department of Energy ..................... 24

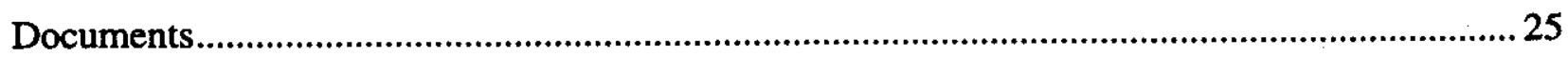


HNF-1901 REV 2

This page intentionally left blank.

G-iv 
HNF-1901 REV 2

APPENDIX G

REFERENCES

\begin{tabular}{|l|}
\hline Acts \\
\hline National Environmental Policy Act of 1969, Pub. L. 91-190, 83 Stat. 852, 42 USC 4321 et seq. \\
\hline $\begin{array}{l}\text { Resource Conservation and Recovery Act of 1976, Pub. L. 94-580, } 90 \text { Stat. 2795, } 42 \text { USC6901 } \\
\text { et seq. }\end{array}$ \\
\hline
\end{tabular}

\section{Code of Federal Regulations}

40 CFR 61.96, "National Emission Standards for Hazardous Air Pollutants; Applications to Construct or Modify," Code of Federal Regulations, as amended.

\section{Washington Administrative Codes}

WAC 173-460, "Controls for New Sources of Toxic Air Pollutants," Washington Administrative Code, as amended.

WAC 246-247, "Radiation Protection-Air Emissions," Washington Administrative Code, as amended.

\section{U.S. Department of Energy Directives}

DOE O 430.1A, 1998, Life Cycle Asset Management, U.S. Department of Energy, Washington, D.C.

DOE Order 5480.22, 1996, Technical Safety Requirements, U.S. Department of Energy, Washington, D.C.

DOE Order 5480.23, 1994, Nuclear Safety Analysis Reports, U.S. Department of Energy, Washington, D.C.

GPG-FM-010, 1996, Project Execution and Engineering Management Planning, Life Cycle Asset Management, Good Practice Guide, U.S. Department of Energy, Washington, D.C.

GPG-FM-012, 1996, Configuration and Data Management, Life Cycle Asset Management, Good Practice Guide, U.S. Department of Energy, Washington, D.C. 
HNF-1901 REV 2

\section{U.S. Department of Energy Directives}

GPG-FM-016, 1996, Baseline Development, Life Cycle Asset Management, Good Practice Guide, U.S. Department of Energy, Washington, D.C.

\section{Databases}

ARMI, n.d., Authorization-Basis Requirements Management Interface the Hanford Site Technical Baseline Database, database maintained by CH2M HILL Hanford Group, Inc., Richland, Washington.

ERMI, n.d., Environmental Requirements Management Interface, database maintained by CH2M HILL Hanford Group, Inc., Richland, Washington.

HSTD, n.d., Hanford Site Technical Baseline Database, database maintained by CH2M HILL Hanford Group, Inc., Richland, Washington.

JCS, n.d., Job Control System, database maintained by CH2M HILL Hanford Group, Inc., Richland, Washington.

\section{Hanford Site Drawings}

Drawing No. H-2-80936, Rev. 3, Area Map Drawing List (1997)

Drawing No. H-2-78870, Rev. 4, TWRS Top Drawing Index (1998)

Drawing No. H-2-79207, Rev. 2, TWRS Drawing Index Tank AZ-101 Drywell/Profile Thermocouple (1997)

Drawing No. H-2-79335, Rev. 2, TWRS - Drawing Index 4-6" Tank 101-AZ Waste Retrieval System (1998)

Drawing No. H-2-131000, Rev. 2, Drawing List (1998)

Drawing No. H-2-818423, Drawing List, Rev. 2 (1998)

Drawing No. H-2-822200, Sheets 1 and 2, Rev. 3, Drawing List (1998)

Drawing No. TWR-2086, Rev. 2, River Protection Project Level-0 Logic (2000) 


\begin{tabular}{|c|}
\hline Hanford Site Specifications \\
\hline V-W151-0002, Rev. 2, Specification for 101-AZ Mixer Pump Variable Speed Drive (1996) \\
\hline V-W151-0003, Rev. 1, Specification for Modifications for Grove Crane at 1100 (1996) \\
\hline $\begin{array}{l}\text { V-W151-0004, Rev. 1, Specification for 101-AZ Sludge Mobilization Monitor Cable and Cable } \\
\text { Reel (1996) }\end{array}$ \\
\hline $\begin{array}{l}\text { W-030-C1, Rev. 1, As-Built Revision } 1 \text { Construction Specification-Site Preparation for Tank } \\
\text { Farm Ventilation Upgrade (1998) }\end{array}$ \\
\hline W-030-C2, Rev. 0, Construction Specification Tank Farm Ventilation Upgrade (1994) \\
\hline $\begin{array}{l}\text { W-058-C1, Rev. 1, Project Turnover Rev. } 1 \text { Technical Requirements Buried Pipeline for } \\
\text { Replacement of the Cross Site Transfer System (1998) }\end{array}$ \\
\hline $\begin{array}{l}\text { W-058-C2, Rev. 2, Project Turnover Rev. } 2 \text { Construction Specification Pipeline Tie-ins for } \\
\text { Replacement of the Cross Site Transfer System (1998) }\end{array}$ \\
\hline $\begin{array}{l}\text { W-058-C3, Rev. 3, Project Turnover Rev. } 3 \text { Construction Specification Diversion Box/Vent } \\
\text { Station for Replacement of the Cross Site Transfer (1998) }\end{array}$ \\
\hline W-058-C4, Rev. 0, Construction Specification Sagebrush Mitigation 600 Area (1996) \\
\hline $\begin{array}{l}\text { W-058-C5, Rev. 1, Project Turnover Rev } 1 \text { Construction Specification Flush System for } \\
\text { Replacement of the Cross Site Transfer System (1998) }\end{array}$ \\
\hline W-058-P1, Project Turnover Rev. 3 Procurement Specification Slurry Transfer Pump (1998) \\
\hline $\begin{array}{l}\text { W-058-P10, Project Turnover Rev. } 1 \text { Procurement Specification Rupture Disk/Relief Valve } \\
\text { (1998) }\end{array}$ \\
\hline $\begin{array}{l}\text { W-058-P11, Rev. 1, Project Turnover Rev. } 1 \text { Procurement Specification Electric Circulation } \\
\text { Heating System (1998) }\end{array}$ \\
\hline $\begin{array}{l}\text { W-058-P12, Rev. 1, Project Turnover Rev. } 1 \text { Procurement Specification Chemical Feed System } \\
\text { (1998) }\end{array}$ \\
\hline $\begin{array}{l}\text { W-058-P13 Rev. } 1 \text { Project Turnover Rev. } 1 \text { Procurement Specification, Calibration and Testing } \\
\text { Laboratory Services (1998) }\end{array}$ \\
\hline $\begin{array}{l}\text { W-058-P2, Rev. 6, Project Turnover Rev. } 5 \text { Procurement Specification Process Monitor and } \\
\text { Control System (1998) }\end{array}$ \\
\hline $\begin{array}{l}\text { W-058-P5, Rev. 3, Project Turnover Rev. } 3 \text { Procurement Specification Process Instruments } \\
\text { (1998) }\end{array}$ \\
\hline
\end{tabular}


HNF-1901 REV 2

\section{Hanford Site Specifications}

W-058-P6, Rev. 2, As-Built Rev. 2 Procurement Specification Horizontal End Suction Centrifugal Pump (1998)

W-058-P8, Rev. 2, As-Built Rev. 2 Procurement Specification Compressed Air System (1998)

W-058-P9, Rev. 2, As-Built Rev. 2 Procurement Specification Air Operated Ball Values (1998)

W-151-C1, Rev. 1, As-Built Revision 1 Construction Specification for Tank 101-AZ Waste Retrieval Systems (1996)

W-151-C2, Rev. 1, As-Built Revision 1 Construction Specification for Tank 101-AZ Waste Retrieval Systems (1996)

W-151-C3, Rev. 1, As-Built Revision 1 Construction Specification for Tank 101-AZ Waste Retrieval Systems (1996)

W-320-C1, Rev. 1, As-Built Rev. I Tank 241-C-106 Sluicing Sitework/Interfarm Piping System (1998)

W-320-C2, Rev. 1, As-Built Rev. 1 Tank 241-C-106 Sluicing Equipment Removal System (1998)

W-320-C5, Rev. 1, as amended, As-Built Rev. 1 Tank 241-C-106 Sluicing C-Tank Farm (1998)

W-320-C6, Rev. 2, As-Built Rev. 2 Tank 241-C-106 Sluicing Process Building Skid Fabrication (1998)

W-320-C7, Rev. 1, As-Built Rev. 1 Tank 241-C-106 Sluicing AY Tank Farm (1998)

W-320-P1, Rev. 0, Procurement Specification Exhaust Skid Ventilation Air Cleanup Trains (1995)

W-320-P17, Rev. 1, Tank 241-C-106 Sluicing (1995)

W-320-P18 Pump, Centrifugal (1997)

W-320-P2, Rev. 1, Procurement Specification Liquid Chiller, Skid Mounted (1995)

W-320-P20, Rev. 0, Procurement Specification Sluicer, Hydraulic Drive and Controls Tank 241-C-106 (1995)

W-320-P22 Air Compressor (1997)

W-320-P23 Air Drier (1997)

W-320-P24, Rev. 0, Procurement Specification Winch, Slurry/Sluice Pump (1995) 


\begin{tabular}{|c|}
\hline Hanford Site Specifications \\
\hline W-320-P3, Rev. 0, Procurement Specification Filter, High Efficiency Metal (1995) \\
\hline W-320-P32, Rev. 0, Procurement Specification Distribution Power Panels (1995) \\
\hline W-320-P33, Rev. 0, Procurement Specification Electrical Equipment Skid AY-Farm (1995) \\
\hline W-320-P34, Rev. 0, Procurement Specification for Electrical Equipment Skid C-Farm (1995) \\
\hline W-320-P35, Rev. 0, Procurement Specification Seismic Shutdown System (1995) \\
\hline W-320-P36, Rev. 0, Procurement Specification for Enclosure and Environmental Control (1995) \\
\hline W-320-P4, Rev. 0, Procurement Specification Heat Exchanger (1995) \\
\hline W-320-P41, Rev. 0, Procurement Specification Isokinetic Air Sampling System (1995) \\
\hline W-320-P44 Seismic Detectors (1997) \\
\hline W-320-P45 Seismic Skids (1997) \\
\hline W-320-P5, Rev. 0, Procurement Specification High Efficiency Mist Eliminator (1995) \\
\hline W-320-P6, Rev. 0, Procurement Specification Fan, Recirculation Cooling (1995) \\
\hline W-320-P7 Rev. 1 Procurement Specification Electric Heating Coils (1997) \\
\hline W-320-P8, Rev. 0, Procurement Specification Moisture Separator (1995) \\
\hline $\begin{array}{l}\text { WHC-S-0037, Rev. 3, Specification for High Pressure Hot Water System Project W-151 } \\
\text { Tank 101-AZ Waste Retrieval System (1996) }\end{array}$ \\
\hline $\begin{array}{l}\text { WHC-S-0040, Rev. 1, Specification for Waste Mobilization Mixer Pump Project W-151 Tank } \\
\text { AZ-101 Waste Retrieval System (1996) }\end{array}$ \\
\hline WHC-S-0099, Rev. 2, Waste Tank Riser - Drywell Mapping Positioner (1994) \\
\hline $\begin{array}{l}\text { WHC-S-0410, Rev. 2, Procurement Specification for 241-AZ-101, W151 Suspended Fixture and } \\
\text { Weld Inspection Camera System (1996) }\end{array}$ \\
\hline
\end{tabular}

\section{Tank Characterization Reports}

Adams, M. R., 1999a, Tank Characterization Report for Double-Shell Tank 241-AN-104, HNF-SD-WM-ER-690, Rev. 1, Lockheed Martin Hanford Corporation, Richland, Washington. 
HNF-1901 REV 2

\section{Tank Characterization Reports}

Adams, M. R., 1999b, Tank Characterization Report for Double-Shell Tank 241-AN-105, HNF-SD-WM-ER-678, Rev. 1, Lockheed Martin Hanford Corporation, Richland, Washington.

Adams, M. R., 1999c, Tank Characterization Report for Double-Shell Tank 241-AW-101, HNF-SD-WM-ER-470, Rev. 2, Lockheed Martin Hanford Corporation, Richland, Washington.

Adams, M. R., 1999d, Tank Characterization Report for Single-Shell Tank 241-BY-105, HNF-SD-WM-ER-598, Rev. 1, Lockheed Martin Hanford Corporation, Richland, Washington.

Adams, M. R., 1999e, Tank Characterization Report for Single-Shell Tank 241-S-110, HNF-SD-WM-ER-642, Rev. 1, Lockheed Martin Hanford Corporation, Richland, Washington.

Adams, M. R., 1999f, Tank Characterization Report for Single-Shell Tank 241-S-111, HNF-SD-WM-ER-638, Rev. 1, Lockheed Martin Hanford Corporation for Fluor Daniel Hanford, Inc., Richland, Washington.

Adams, M. R., 1999g, Preliminary Tank Characterization Report for Single-Shell Tank 241-SX-102: Best-Basis Inventory, HNF-SD-WM-ER-661, Rev. 1, Lockheed Martin Hanford Corporation, Richland, Washington.

Adams, M. R., 1999h, Tank Characterization Report for Single-Shell Tank 241-SX-105, HNF-SD-WM-ER-644, Rev. 1, Lockheed Martin Hanford Corporation, Richland, Washington.

Adams, M. R., 1999i, Tank Characterization Report for Single-Shell Tank 241-T-110, HNF-SD-WM-ER-686, Rev. 2, Lockheed Martin Hanford Corporation, Richland, Washington.

Adams, M. R., 1999j, Tank Characterization Report for Single-Shell Tank 241-U-107, HNF-SD-WM-ER-614, Rev. 1, Lockheed Martin Hanford Corporation, Richland, Washington.

Adams, M. R., 1999k, Tank Characterization Report for Single-Shell Tank 241-U-109, WHC-SD-WM-ER-609, Rev. 1, Lockheed Martin Hanford Corporation, Richland, Washington.

Adams, M. R, 1999l, Tank Characterization Report for Single-Shell Tank 241-U-112, HNF-SD-WM-ER-720, Rev. 2, Lockheed Martin Hanford Corporation, Richland, Washington. 


\section{Tank Characterization Reports}

Adams, M. R., 2000a, Tank Characterization Report for Double-Shell Tank 241-AN-101, HNF-SD-WM-ER-578, Rev. 1, CH2M HILL Hanford Group, Inc., Richland, Washington.

Adams, M. R., 2000b, Tank Characterization Report for Double-Shell Tank 241-AN-107, WHC-SD-WM-ER-600, Rev. 1, CH2M HILL Hanford Group, Inc., Richland, Washington.

Adams, M. R., 2000c, Tank Characterization Report for Single-Shell Tank 241-C-104, HNF-SD-WM-ER-679, Rev. 1, CH2M HILL Hanford Group, Inc., Richland, Washington.

Adams, M. R., 2000d, Tank Characterization Report for Single-Shell Tank 241-U-102, HNF-SD-WM-ER-618, Rev. 1, CH2M HILL Hanford Group, Inc., Richland, Washington.

Adams, M. L., 2000e, Tank Characterization Report for Single-Shell Tank 241-U-103, HNF-SD-WM-ER-712, Rev. 2, CH2M HILL Hanford Group, Inc., Richland, Washington.

Adams, M. R., 2000f, Tank Characterization Report for Single-Shell Tank 241-U-105, HNF-SD-WM-ER-617, Rev. 1, CH2M HILL Hanford Group, Inc., Richland, Washington.

Amato, L. C., K. W. Johnson, T. T. Tran, and W. I. Winters, 1995, Tank Characterization Report for Single-Shell Tank 241-B-102, WHC-SD-WM-ER-405, Rev. 0, as amended, Westinghouse Hanford Company, Richland, Washington.

Amato, L. C., T. T. Tran, K. D. Fowler, S. R. Wilmarth, L. J. Fergestrom, and S. L. Lambert, 1998, Tank Characterization Report for Double-Shell Tank 241-AW-104, HNF-SD-WM-ER-453, Rev. 1, Fluor Daniel Hanford, Inc., Richland, Washington.

Amato, L. C., B. C. Simpson, and S. R. Wilmarth, 1999, Tank Characterization Report for Single-Shell Tank 241-AX-104, HNF-SD-WM-ER-675, Rev. 2, as amended, Fluor Daniel Hanford, Inc., Richland, Washington.

Anantatmula, R. P., and S. R. Wilmarth, 1998, Tank Characterization Report for Single-Shell Tank 241-BX-111, HNF-SD-WM-ER-653, Rev. 1, Lockheed Martin Hanford Corporation for Fluor Daniel Hanford, Inc., Richland, Washington.

Anantatmula, R. P., and S. R. Wilmarth, 1999, Tank Characterization Report for Single-Shell Tank 241-S-102, HNF-SD-WM-ER-611, Rev. 1, as amended, Lockheed Martin Hanford Corporation, Fluor Daniel Hanford, Inc., Richland, Washington. 


\section{Tank Characterization Reports}

Anantatmula, R. P., J. G. Field, and S. R. Wilmarth, 1998, Tank Characterization Report for Single-Shell Tanks 241-C-201 and C-202, Rev. 0, Fluor Daniel Hanford, Inc., Richland, Washington.

Baldwin, J. H., and R. H. Stephens, 1996, Tank Characterization Report for Double-Shell Tank 241-AP-108, WHC-SD-WM-ER-593, Rev. 0, as amended, Westinghouse Hanford Company, Richland, Washington.

Baldwin, J. H., and J. D. Franklin, 1997, Tank Characterization Report for Double-Shell Tank 241-AP-102, HNF-SD-WM-ER-358, Rev. 1, as amended, Lockheed Martin Hanford Corporation for Fluor Daniel Hanford Inc., Richland, Washington.

Baldwin, J. H., L. C. Amato, and T. T. Tran, 1995, Tank Characterization Report for Single-Shell Tank 241-SX-113, WHC-SD-WM-ER-480, Rev. 0, as amended, Westinghouse Hanford Company, Richland, Washington.

Baldwin, J. H., L. C. Amato, and B. J. Morris, 1996a, Tank Characterization Report for Single-Shell Tank 241-T-108, WHC-SD-WM-ER-554, Rev. 0, as amended, Westinghouse Hanford Company, Richland, Washington.

Baldwin, J. H., R. J. Cash, W. I. Winters, L. Amato, and T. Tran, 1996b, Tank Characterization Report for Single-Shell Tank 241-BY-108, WHC-SD-WM-ER-533, Rev. 0, as amended, Westinghouse Hanford Company, Richland, Washington.

Baldwin, J. H., R. D. Cromar, L. Fergestrom, and S. L. Lambert, 1997a, Tank Characterization Report for Single-Shell Tank 241-T-102, HNF-SD-WM-ER-700, Rev. 0, Rev. 0, as amended, Lockheed Martin Hanford Corporation for Fluor Daniel Hanford, Inc., Richland, Washington.

Baldwin, J. H., M. J. Kupfer, R. D. Cromar, R. T. Winward, and L. Fergestrom, 1997b, Tank Characterization Report for Single-Shell Tank 241-BY-112, HNF-SD-WM-ER-701, Rev. 0, as amended, Lockheed Martin Hanford Corporation for Fluor Daniel Hanford, Inc., Richland, Washington.

Bell, K. E., 1996, Tank Characterization Report for Single-Shell Tank 241-BX-103, WHC-SD-WM-ER-535, Rev. 0, as amended, Westinghouse Hanford Company, Richland, Washington.

Bell, K. E., and R. D. Cromar, 1997, Tank Characterization Report for Single-Shell Tank 241-U-108, HNF-SD-WM-ER-639, Rev. 0, as amended, Lockheed Martin Hanford Corporation for Fluor Daniel Hanford Inc., Richland, Washington. 


\section{Tank Characterization Reports}

Bell, K. E., J. D. Franklin, R. H. Stephens, R. G. Hale, C. McDonald, D. Lauhala, and M. Umphrey, 1995, Tank Characterization Report for Single-Shell Tank 241-C-107, WHC-SD-WM-ER-474, Rev. 0, as amended, Westinghouse Hanford Company, Richland, Washington.

Bell, K. E., J. Franklin, J. Stroup, and J. L. Huckaby, 1996, Tank Characterization Report for Single-Shell Tank 241-BY-106, WHC-SD-WM-ER-616, Rev. 0, Westinghouse Hanford Company, Richland, Washington.

Bell, K. E., L. Fergestrom, T. Jones, and T. Welch, 1997, Tank Characterization Report for Double-Shell Tank 241-AW-102, HNF-SD-WM-ER-363, Rev. 1, as amended, Lockheed Martin Hanford Corporation for Fluor Daniel Hanford, Inc., Richland, Washington.

Benar, C. J., J. G. Field, and L. C. Amato, 1996, Tank Characterization Report for Single-Shell Tank 241-BY-104, WHC-SD-WM-ER-608, Rev. 0, Westinghouse Hanford Company, Richland, Washington.

Benar, C. J., R. D. Cromar, and S. L. Lambert, 1997a, Tank Characterization Report for Single-Shell Tank 241-C-110, HNF-SD-WM-ER-367, Rev. 1, as amended, Lockheed Martin Hanford Corporation for Fluor Daniel Hanford, Inc., Richland, Washington.

Benar, C. J., B. A. Higley, K. W. Johnson, and L. Jensen, 1997b, Tank Characterization Report for Single-Shell Tank 241-B-111, HNF-SD-WM-ER-549, Rev. 1, as amended, Lockheed Martin Hanford Corporation for Fluor Daniel Hanford, Inc., Richland, Washington.

Benar, C. J., M. J. Kupfer, and R. D. Cromar, 1997c, Tank Characterization Report for Single-Shell Tank 241-B-109, HNF-SD-WM-ER-677, Rev. 0, as amended, Lockheed Martin Hanford Corporation for Fluor Daniel Hanford, Inc., Richland, Washington.

Brown, T. M., L. M. Sasaki, R. D. Cromar, N. G. Colton, J. L. Stroup, J. D. Franklin, and L. J. Fergestrom, 1996, Tank Characterization Report for Single-Shell Tank 241-T-109, WHC-SD-WM-ER-559, Rev. 0, as amended, Westinghouse Hanford Company, Richland, Washington.

Brown, T. M., R. D. Cromar, J. L. Stroup, and R. T. Winward, 1997, Tank Characterization Report for Single-Shell Tank 241-U-106, HNF-SD-WM-ER-636, Rev. 0, as amended, Lockheed Martin Hanford Corporation for Fluor Daniel Hanford Inc., Richland, Washington.

Conner, J. M., 1995, Tank Characterization Report for Single-Shell Tank 241-B-103, WHC-SD-WM-ER-488, Rev. 0, as amended, Westinghouse Hanford Company, Richland, Washington. 


\section{Tank Characterization Reports}

Conner, J. M., 1996, Tank Characterization Report for Single-Shell Tank 241-C-204, WHC-SD-WM-ER-479, Rev. 0, as amended, Westinghouse Hanford Company, Richland, Washington.

Conner, J. M., K. M. Hodgson, L. C. Amato, J. L. Stroup, S. R. Wilmarth, and R. T. Winward, 1997a, Tank Characterization Report for Single-Shell Tank 241-B-201, HNF-SD-WM-ER-550, Rev. 1, as amended, Lockheed Martin Hanford Corporation for Fluor Daniel Hanford, Inc., Richland, Washington.

Conner, J. M., L. W. Shelton, Jr., L. C. Amato, T. L. Welsh, and J. L. Stroup, 1997b, Tank Characterization Report for Double-Shell Tank 241-AP-101, HNF-SD-WM-ER-357, Rev. 1, as amended, Lockheed Martin Hanford Corporation for Fluor Daniel Hanford Inc., Richland, Washington.

Conner, J. M., L. Jensen, S. R. Wilmarth, and L. J. Fergestrom, 1998a, Tank Characterization Report for Single-Shell Tank 241-AZ-103, HNF-SD-WM-ER-685, Rev. 1, Fluor Daniel Hanford, Inc., Richland, Washington.

Conner, J. M., S. R. Wilmarth, and L. J. Fergestrom, 1998b, Tank Characterization Report for Single-Shell Tank 241-B-107, HNF-SD-WM-ER-723, Rev. 1, Lockheed Martin Hanford Corporation for Fluor Daniel Hanford, Inc., Richland, Washington.

Dougherty, L. F., 1995a, Tank Characterization Report for Single-Shell Tank 241-B-202, HNF-SD-WM-ER-371, Rev. 0, as amended, Westinghouse Hanford Company, Richland, Washington.

Dougherty, L. F., 1995b, Tank Characterization Report for Single-Shell Tank 241-B-112, WHC-SD-WM-ER-466, Rev. 0, as amended, Westinghouse Hanford Company, Richland, Washington.

Douglas, J. G., B. J. Morris, and T. T. Tran, 1996, Tank Characterization Report for Double-Shell Tank 241-AN-106, WHC-SD-WM-ER-569, Rev. 0, as amended, Westinghouse Hanford Company, Richland, Washington.

Douglas, J. G., L. J. Fergestrom, and S. R. Wilmarth, 1998, Tank Characterization Report for Double-Shell Tank 241-SY-102, HNF-SD-WM-ER-366, Rev. 1, as amended, Fluor Daniel Hanford, Inc., Richland, Washington.

Eggers, R. F., J. D. Franklin, B. J. Morris, and T. T. Tran, 1996, Tank Characterization Report for Single-Shell Tank 241-SX-108, WHC-SD-WM-ER-582, Rev. 0, as amended, Westinghouse Hanford Company, Richland, Washington.

Field, J. G. and S. R. Wilmarth, 1998a, Tank Characterization Report for Single-Shell Tank 241-AX-101, HNF-SD-WM-ER-649, Rev. 1, Lockheed Martin Hanford Corporation for Fluor Daniel Hanford, Inc., Richland, Washington. 


\section{Tank Characterization Reports}

Field, J. G., and S. R. Wilmarth, 1998b, Tank Characterization Report for Single-Shell Tank 241-T-105, HNF-SD-WM-ER-369, Rev. 2, as amended, Lockheed Martin Hanford Corporation for Fluor Daniel Hanford, Inc., Richland, Washington.

Field, J. G., J. Jo, and T. T. Trans, 1996a, Tank Characterization Report for Single-Shell Tank 241-B-104, WHC-SD-WM-ER-552, Rev. 0, Westinghouse Hanford Company, Richland, Washington.

Field, J. G., R. D. Schreiber, and B. C. Simpson, 1996b, Tank Characterization Report for Single-Shell Tank 241-BX-109, WHC-SD-ER-572, Rev. 0, as amended, Westinghouse Hanford Company, Richland, Washington.

Field, J. G., J. H. Baldwin, M. J. Kupfer, and L. Jensen, 1997a, Tank Characterization Report for Single-Shell Tank 241-T-111, HNF-SD-WM-ER-540, Rev. 1, as amended, Lockheed Martin Hanford Corporation for Fluor Daniel Hanford, Inc., Richland, Washington.

Field, J. G., B. A. Higley, L. Jensen, and L. L. Parkhill, 1997b, Tank Characterization Report for Single-Shell Tank 241-B-110, HNF-SD-WM-ER-368, Rev. 1, as amended, Lockheed Martin Hanford Corporation for Fluor Daniel Hanford, Inc., Richland, Washington.

Field, J. G., D. E. Place, and R. D. Cromar, 1997c, Tank Characterization Report for Single-Shell Tank 241-A-101, HNF-SD-WM-ER-673, Rev. 0, as amended, Lockheed Martin Hanford Corporation for Fluor Daniel Hanford, Inc., Richland, Washington.

Field, J. G., L. W. Shelton, and R. D. Cromar, 1997d, Tank Characterization Report for Double-Shell Tank 241-AP-107, HNF-SD-WM-ER-362, Rev. 1, as amended, Lockheed Martin Hanford Corporation for Fluor Daniel Hanford, Inc., Richland, Washington.

Field, J. G, L. W. Shelton, R. D. Cromar, and B. Morris, 1997e, Tank Characterization Report for Double-Shell Tank 241-AP-103, HNF-SD-WM-ER-359, Rev. 1, as amended, Lockheed Martin Hanford Corporation for Fluor Daniel Hanford Inc., Richland, Washington.

Field, J. G., T. L. Welsh, and T. Jones, 1997f, Tank Characterization Report for Double-Shell Tank 241-AW-106, HNF-SD-WM-ER-365, Rev. 1, as amended, Lockheed Martin Hanford Corporation for Fluor Daniel Hanford Inc., Richland, Washington.

Field, J. G., R. T. Winward, and S. R. Wilmarth, $1997 \mathrm{~g}$, Tank Characterization Report for Single-Shell Tank 241-S-109, HNF-SD-WM-ER-627, Rev. 0, as amended, Lockheed Martin Hanford Corporation for Fluor Daniel Hanford, Inc., Richland, Washington.

Field, J. G., S. R. Wilmarth, and M. D. Crippen, 1998a, Tank Characterization Report for Double-Shell Tank 241-AW-103, WHC-SD-WM-ER-455, Rev. 1, as amended, Lockheed Martin Hanford Corporation for Fluor Daniel Hanford, Inc., Richland, Washington. 


\section{Tank Characterization Reports}

Field, J. G., S. R. Wilmarth, and G. L. Miller, 1998b, Tank Characterization Report for Single-Shell Tank 241-S-106, HNF-SD-WM-ER-714, Rev. 1, as amended, Lockheed Martin Hanford Corporation for Fluor Daniel Hanford, Inc., Richland, Washington.

Field, J. G., A. M. Templeton, and S. R. Wilmarth, 1999, Tank Characterization Report for Single-Shell Tank 241-TX-104, HNF-SD-WM-ER-672, Rev. 1, Lockheed Martin Hanford Corporation for Fluor Daniel Hanford, Inc., Richland, Washington.

Hall, B. W., 1995, Tank Characterization Report for Single-Shell Tank 241-C-101, WHC-SD-WM-ER-473, Rev. 0, as amended, Westinghouse Hanford Company, Richland, Washington.

Hall, B. W., and T. T. Tran, 1995, Tank Characterization Report for Single-Shell Tank 24I-BX-105, WHC-SD-WM-ER-406, Rev. 0, Westinghouse Hanford Company, Richland, Washington.

Hansen, D. R., S. G. Metcalf, J. G. Douglas, W. I. Winters, K. W. Johnson, and J. D. Franklin, 1996, Tank Characterization Report for Double-Shell Tank 241-SY-103, WHC-SD-WM-ER-471, Rev. 1, as amended, Westinghouse Hanford Company, Richland, Washington.

Hendrickson, D. W., 1997a, Preliminary Tank Characterization Report for Single-Shell Tank 241-TX-103: Best-Basis Inventory, HNF-SD-WM-ER-704, Rev. 0, SGN Eurisys

Services for Fluor Daniel Hanford, Inc., Richland, Washington.

Hendrickson, D. W., 1997b, Preliminary Tank Characterization Report for Single-Shell

Tank 241-TY-103: Best-Basis Inventory, HNF-SD-WM-ER-703, Rev. 0, as amended, Lockheed Martin Hanford Corporation for Fluor Daniel Hanford, Inc., Richland, Washington.

Herting, D. L., T. L. Welsh, R. W. Lambie, and T. T. Tran, 1995, Tank Characterization Report for Double-Shell Tank 241-SY-101, WHC-SD-WM-ER-409, Rev. 0, as amended, Westinghouse Hanford Company, Richland, Washington.

Higley, B. A., and J. G. Field, 1997a, Preliminary Tank Characterization Report for Single-Shell Tank 241-A-103: Best Basis Inventory, HNF-SD-WM-ER-709, Rev. 0, Lockheed Martin Hanford Corporation for Fluor Daniel Hanford, Inc., Richland, Washington.

Higley, B. A., and J. G. Field, 1997b, Preliminary Tank Characterization Report for Single-Shell Tank 241-B-105: Best-Basis Inventory, HNF-SD-WM-ER-722, Rev. 0, Lockheed Martin Hanford Corporation for Fluor Daniel Hanford, Inc., Richland, Washington.

Hodgson, K. M., and T. T. Tran, 1995, Tank Characterization Report for Double-Shell Tank 241-AZ-101, WHC-SD-WM-ER-410, Rev. 0, as amended, Westinghouse Hanford Company, Richland, Washington. 


\section{Tank Characterization Reports}

Hodgson, K. M., and J. G. Field, 1997a, Preliminary Tank Characterization Report for Single-Shell Tank 241-A-104: Best Basis Inventory, HNF-SD-WM-ER-666, Rev. 0, Lockheed Martin Hanford Corporation for Fluor Daniel Hanford, Inc., Richland, Washington.

Hodgson, K. M. and J. G. Field, 1997b, Preliminary Tank Characterization Report for Single-Shell Tank 241-A-105: Best Basis Inventory, HNF-SD-WM-ER-667, Rev. 0, Lockheed Martin Hanford Corporation for Fluor Daniel Hanford, Inc., Richland, Washington.

Hu, T. A., and R. H. Stephens, 1996, Tank Characterization Report for Single-Shell Tank 241-BX-104, WHC-SD-WM-ER-599, Rev. 0, Westinghouse Hanford Company, Richland, Washington.

Hu, T. A., S. R. Wilmarth, M. D. Crippen, and L. Fergestrom, 1998a, Tank Characterization Report for Single-Shell Tank 241-SX-101, HNF-SD-WM-ER-660, Rev. 1, as amended, Lockheed Martin Hanford Corporation for Fluor Daniel Hanford, Inc., Richland, Washington.

Hu, T. A., S. R. Wilmarth, and J. G. Douglas, 1998b, Tank Characterization Report for Double-Shell Tank 241-AP-105, HNF-SD-WM-ER-360, Rev. 2, as amended, Lockheed Martin Hanford Corporation for Fluor Daniel Hanford Inc., Richland, Washington.

Hulse, N. L., L. C. Amato, and S. R. Wilmarth, 1999, Tank Characterization Report for Single-Shell Tank 241-SX-115, HNF-SD-WM-ER-684, Rev. 1, Lockheed Martin Hanford Corporation for Fluor Daniel Hanford, Inc., Richland, Washington.

Jo, J., and A. T. DiCenso, 1995, Tank Characterization Report for Single-Shell

Tank 241-TY-106, WHC-SD-WM-ER-482, Rev. 0, as amended, Westinghouse Hanford Company, Richland, Washington.

Jo, J., L. C. Amato, J. D. Franklin, and T. T. Tran, 1996a, Tank Characterization Report for Single-Shell Tank 241-T-106, WHC-SD-WM-ER-544, Rev. 0, as amended, Westinghouse Hanford Company, Richland, Washington.

Jo, J., L. C. Amato, and T. T. Tran, 1996b, Tank Characterization Report for Single-Shell Tank 241-B-203, WHC-SD-WM-ER-587, Rev. 0, Westinghouse Hanford Company, Richland, Washington.

Jo, J., B. J. Morris, and T. T. Tran, 1996c, Tank Characterization Report for Single-Shell Tank 241-A-102, WHC-SD-WM-ER-597, Rev. 0, as amended, Westinghouse Hanford Company, Richland, Washington. 


\section{Tank Characterization Reports}

Jo, J., 1997, Preliminary Tank Characterization Report for Single-Shell Tank 241-TX-108: Best-Basis Inventory, HNF-SD-WM-ER-717, Rev. 0, as amended, Lockheed Martin Hanford Corporation for Fluor Daniel Hanford, Inc., Richland, Washington.

Jo, J., and D. E. Place, 1997, Preliminary Tank Characterization Report for Single-Shell Tank 241-TX-118: Best-Basis Inventory, HNF-SD-WM-ER-718, Rev. 0, as amended, Lockheed Martin Hanford Corporation for Fluor Daniel Hanford, Inc., Richland, Washington.

Jo, J., R. D. Cromar, and R. T. Winward, 1997a, Tank Characterization Report for Single-Shell Tank 241-S-104, HNF-SD-WM-ER-370, Rev. 1, as amended, Lockheed Martin Hanford Corporation for Fluor Daniel Hanford, Inc., Richland, Washington.

Jo, J., R. T. Winward, and R. Cromar, 1997b, Tank Characterization Report for Single-Shell Tank 241-BY-111, HNF-SD-WM-ER-687, Rev. 0, as amended, Lockheed Martin Hanford Corporation for Fluor Daniel Hanford, Inc., Richland, Washington.

Jo, J., S. R. Wilmarth, and L. Fergestrom, 1998, Tank Characterization Report for Single-Shell Tank 241-BY-109, HNF-SD-WM-ER-648, Rev. 1, Lockheed Martin Hanford Corporation for Fluor Daniel Hanford, Inc., Richland, Washington.

Kruger, A. A., B. J. Morris, and L. J. Fergestrom, 1996, Tank Characterization Report for Single-Shell Tank 241-S-101, WHC-SD-WM-ER-613, Rev. 0, as amended, Westinghouse Hanford Company, Richland, Washington.

Kupfer, M. J., and W. W. Schulz, 1997, Preliminary Tank Characterization Report for Single-Shell Tank 241-SX-107: Best-Basis Inventory, HNF-SD-WM-ER-671, Rev. 0, as amended, Lockheed Martin Hanford Corporation for Fluor Daniel Hanford, Inc., Richland, Washington.

Kupfer, M. J., and R. T. Winward, 1997a, Preliminary Tank Characterization Report for Single-Shell Tank 241-A-106: Best Basis Inventory, HNF-SD-WM-ER-721, Rev. 0, as amended, Lockheed Martin Hanford Corporation for Fluor Daniel Hanford, Inc., Richland, Washington.

Kupfer, M. J., and R. T. Winward, 1997b, Preliminary Tank Characterization Report for Single-Shell Tank 241-BX-102: Best-Basis Inventory, HNF-SD-WM-ER-724, Rev. 0, as amended, Lockheed Martin Hanford Corporation for Fluor Daniel Hanford, Inc., Richland, Washington.

Kupfer, M. J., and R. T. Winward, 1997c, Preliminary Tank Characterization Report for Single-Shell Tank 241-BY-101: Best-Basis Inventory, HNF-SD-WM-ER-647, Rev, 0, as amended, Lockheed Martin Hanford Corporation for Fluor Daniel Hanford, Inc., Richland, Washington. 


\section{Tank Characterization Reports}

Kupfer, M. J., and R. T. Winward, 1997d, Preliminary Tank Characterization Report for Single-Shell Tank 241-BY-103: Best-Basis Inventory, HNF-SD-WM-ER-663, Rev. 0, as amended, Lockheed Martin Hanford Corporation for Fluor Daniel Hanford, Inc., Richland, Washington.

Kupfer, M. J., and R. T. Winward, 1997e, Preliminary Tank Characterization Report for Single-Shell Tank 241-S-103: Best-Basis Inventory, HNF-SD-WM-ER-668, Rev. 0, as amended, Lockheed Martin Hanford Corporation for Fluor Daniel Hanford, Inc., Richland, Washington.

Kupfer, M. J., and R. T. Winward, 1997f, Preliminary Tank Characterization Report for Single-Shell Tank 241-U-101: Best-Basis Inventory, HNF-SD-WM-ER-732, Rev. 0, as amended, Lockheed Martin Hanford Corporation for Fluor Daniel Hanford, Inc., Richland, Washington.

Kupfer, M. J., T. E. Jones, and R. T. Winward, 1997a, Preliminary Tank Characterization Report for Single-Shell Tank 241-TX-101: Best-Basis Inventory, HNF-SD-WM-ER-689, Rev. 0, as amended, Lockheed Martin Hanford Corporation for Fluor Daniel Hanford, Inc., Richland, Washington.

Kupfer, M. J., T. E. Jones, and R. T. Winward, 1997b, Preliminary Tank Characterization Report for Single-Shell Tank 241-TX-102: Best-Basis Inventory, HNF-SD-WM-ER-654, Rev. 0, as amended, Lockheed Martin Hanford Corporation for Fluor Daniel Hanford, Inc., Richland, Washington.

Kupfer, M. J., T. E. Jones, and R. T. Winward, 1997c, Preliminary Tank Characterization Report for Single-Shell Tank 241-TX-105: Best-Basis Inventory, HNF-SD-WM-ER-655, Rev. 0, as amended, Lockheed Martin Hanford Corporation for Fluor Daniel Hanford, Inc., Richland, Washington.

Kupfer, M. J., T. E. Jones, and R. T. Winward, 1997d, Preliminary Tank Characterization Report for Single-Shell Tank 241-TX-106: Best-Basis Inventory, HNF-SD-WM-ER-656, Rev. 0, Lockheed Martin Hanford Corporation for Fluor Daniel Hanford, Inc., Richland, Washington.

Kupfer, M. J., T. E. Jones, and R. T. Winward, 1997e, Preliminary Tank Characterization Report for Single-Shell Tank 241-TX-115: Best-Basis Inventory, HNF-SD-WM-ER-657, Rev. 0, as amended, Lockheed Martin Hanford Corporation for Fluor Daniel Hanford, Inc., Richland, Washington.

Kupfer, M. J., W. W. Schulz, and T. E. Jones, 1997f, Preliminary Tank Characterization Report for Single-Shell Tank 241-SX-109: Best-Basis Inventory, HNF-SD-WM-ER-706, Rev. 0, as amended, Lockheed Martin Hanford Corporation for Fluor Daniel Hanford, Inc., Richland, Washington. 


\section{Tank Characterization Reports}

Kupfer, M. J., W. W. Schulz, and T. E. Jones, 1997g, Preliminary Tank Characterization Report for Single-Shell Tank 241-SX-114: Best-Basis Inventory, HNF-SD-WM-ER-707, Rev. 0, as amended, Lockheed Martin Hanford Corporation for Fluor Daniel Hanford, Inc., Richland, Washington.

Kupfer, M. J., W. W. Schulz, and T. E. Jones, 1997h, Preliminary Tank Characterization Report for Single-Shell Tank 241-TY-105: Best-Basis Inventory, HNF-SD-WM-ER-652, Rev. 0, as amended, Lockheed Martin Hanford Corporation for Fluor Daniel Hanford, Inc., Richland, Washington.

Kupfer, M. J., W. W. Schulz, and R. T. Winward, 1997i, Preliminary Tank Characterization Report for Single-Shell Tank 241-SX-110: Best-Basis Inventory, HNF-SD-WM-ER-681, Rev. 0, as amended, Lockheed Martin Hanford Corporation for Fluor Daniel Hanford, Inc., Richland, Washington.

Kupfer, M. J., W. W. Schulz, and R. T. Winward, 1997j, Preliminary Tank Characterization Report for Single-Shell Tank 241-SX-111: Best-Basis Inventory, HNF-SD-WM-ER-682, Rev. 0, as amended, Lockheed Martin Hanford Corporation for Fluor Daniel Hanford, Inc., Richland, Washington.

Kupfer, M. J., W. W. Schulz, and R. T. Winward, 1997k, Preliminary Tank Characterization Report for Single-Shell Tank 241-SX-112: Best-Basis Inventory, HNF-SD-WM-ER-683, Rev. 0, as amended, Lockheed Martin Hanford Corporation for Fluor Daniel Hanford, Inc., Richland, Washington.

Kupfer, M. J., W. W. Schulz, and R. T. Winward, 1997l, Preliminary Tank Characterization Report for Single-Shell Tank 241-U-104: Best-Basis Inventory, HNF-SD-WM-ER-650, Rev. 0, as amended, Lockheed Martin Hanford Corporation for Fluor Daniel Hanford, Inc., Richland, Washington.

Kupfer, M. J., R. E. Stout, and R. T. Winward, 1997m, Preliminary Tank Characterization Report for Single-Shell Tank 241-S-105: Best-Basis Inventory, HNF-SD-WM-ER-669, Rev. 0, as amended, Lockheed Martin Hanford Corporation for Fluor Daniel Hanford, Inc., Richland, Washington.

Kupfer, M. J., R. E. Stout, and R. T. Winward, 1997n, Preliminary Tank Characterization Report for Single-Shell Tank 241-S-108: Best-Basis Inventory, HNF-SD-WM-ER-641, Rev. 0, as amended, Lockheed Martin Hanford Corporation for Fluor Daniel Hanford, Inc., Richland, Washington.

Kupfer, M. J., R. E. Stout, and R. T. Winward, 1997o, Preliminary Tank Characterization Report for Single-Shell Tank 241-S-112: Best-Basis Inventory, HNF-SD-WM-ER-670, Rev. 0, as amended, Lockheed Martin Hanford Corporation for Fluor Daniel Hanford, Inc., Richland, Washington. 


\section{Tank Characterization Reports}

Kupfer, M. J., R. E. Stout, and R. T. Winward, 1997p, Preliminary Tank Characterization Report for Single-Shell Tank 241-SX-104: Best-Basis Inventory, HNF-SD-WM-ER-643, Rev. 0, as amended, Lockheed Martin Hanford Corporation for Fluor Daniel Hanford, Inc., Richland, Washington.

Kupfer, M. J., R. E. Stout, and R. T. Winward, 1997q, Preliminary Tank Characterization Report for Single-Shell Tank 241-SX-106: Best-Basis Inventory, HNF-SD-WM-ER-645, Rev. 0, Lockheed Martin Hanford Corporation for Fluor Daniel Hanford, Inc., Richland, Washington.

Kupfer, M. J., R. E. Stout, and R. T. Winward, 1997r, Preliminary Tank Characterization Report for Single-Shell Tank 241-U-111: Best-Basis Inventory, HNF-SD-WM-ER-713, Rev. 0, as amended, Lockheed Martin Hanford Corporation for Fluor Daniel Hanford, Inc., Richland, Washington.

Lambert, S. L., 1997a, Preliminary Tank Characterization Report for Single-Shell Tank 241-C-102: Best-Basis Inventory, HNF-SD-WM-ER-651, Rev. 0, as amended, SGN Eurisys Services Corporation for Fluor Daniel Hanford, Inc., Richland, Washington.

Lambert, S. L., 1997b, Preliminary Tank Characterization Report for Single-Shell Tank 241-T-101: Best-Basis Inventory, HNF-SD-WM-ER-710, Rev. 0, as amended, SGN Eurisys Services Corporation for Fluor Daniel Hanford, Inc., Richland, Washington.

Lambert, S. L., 1997c, Preliminary Tank Characterization Report for Single-Shell Tank 241-T-103: Best-Basis Inventory, HNF-SD-WM-ER-725, Rev. 0, as amended, SGN Eurisys Services Corporation for Fluor Daniel Hanford, Inc., Richland, Washington.

Lambert, S. L., 1997d, Preliminary Tank Characterization Report for Single-Shell Tank 241-TY-101: Best-Basis Inventory, HNF-SD-WM-ER-646, Rev. 0, as amended, Lockheed Martin Hanford Corporation for Fluor Daniel Hanford, Inc., Richland, Washington.

Lambert, S. L. and D. W. Hendrickson, 1997, Preliminary Tank Characterization Report for Single-Shell Tank 241-AX-103: Best-Basis Inventory, HNF-SD-WM-ER-686, Rev. 0, prepared by SGN Eurisys Services Corporation for Fluor Daniel Hanford, Inc., Richiand, Washington.

Lechelt, J. A., L. C. Amato, and T. T. Tran, 1995, Tank Characterization Report for Single-Shell Tank 241-C-203, WHC-SD-WM-ER-478, Rev. 0, as amended, Westinghouse Hanford Company, Richland, Washington. 


\section{Tank Characterization Reports}

Lindquist, C. J., and S. R. Wilmarth, 1999, Tank Characterization Report for Single-Shell Tank 241-SX-103, HNF-SD-WM-ER-662, Rev. 1, Lockheed Martin Hanford Corporation for Fluor Daniel Hanford, Inc., Richland, Washington.

McCain, D. J., B. C. Simpson, and L. C. Amato, 1996, Tank Characterization Report for Single-Shell Tank 241-B-106, WHC-SD-WM-ER-601, Rev. 0, as amended, Westinghouse Hanford Company, Richland, Washington.

McCain, D. J., M. J. Kupfer, R. D. Cromar, J. L. Stroup, and L. Fergestrom, 1997, Tank Characterization Report for Single-Shell Tank 241-BY-107, HNF-SD-WM-ER-637, Rev. 0, as amended, Fluor Daniel Hanford, Inc., Richland, Washington.

McCain, D. J., S. R. Wilmarth, and L. Fergestrom, 1998, Tank Characterization Report for Single-Shell Tank 241-T-112, HNF-SD-WM-ER-699, Rev. 1, Lockheed Martin Hanford Corporation for Fluor Daniel Hanford, Inc., Richland, Washington.

Milliken, N. J., 1995a, Tank Characterization Report for Single-Shell Tank 241-BX-101, WHC-SD-WM-ER-408, Rev. 0, as amended, Westinghouse Hanford Company, Richland, Washington.

Milliken, N. J., 1995b, Tank Characterization Report for Single-Shell Tank 241-U-202, WHC-SD-WM-ER-484, Rev. 0, as amended, Westinghouse Hanford Company, Richland, Washington.

Place, D. E., 1997a, Preliminary Tank Characterization Report for Single-Shell Tank 241-TX-109: Best-Basis Inventory, HNF-SD-WM-ER-640, Rev. 0, as amended, SGN Eurisys Services Corporation for Fluor Daniel Hanford, Inc., Richland, Washington.

Place, D. E., 1997b, Preliminary Tank Characterization Report for Single-Shell Tank 241-TX-110: Best-Basis Inventory, HNF-SD-WM-ER-658, Rev. 0, as amended, SGN Eurisys Services Corporation for Fluor Daniel Hanford, Inc., Richland, Washington.

Place, D. E., 1997c, Preliminary Tank Characterization Report for Single-Shell Tank 241-TX-111: Best-Basis Inventory, HNF-SD-WM-ER-659, Rev. 0, as amended, SGN Eurisys Services Corporation for Fluor Daniel Hanford, Inc., Richland, Washington.

Place, D. E., 1997d, Preliminary Tank Characterization Report for Single-Shell Tank 241-TX-112: Best-Basis Inventory, HNF-SD-WM-ER-715, Rev. 0, as amended, SGN Eurisys Services Corporation for Fluor Daniel Hanford, Inc., Richland, Washington. 


\section{Tank Characterization Reports}

Place, D. E., 1997e, Preliminary Tank Characterization Report for Single-Shell

Tank 241-TX-113: Best-Basis Inventory, HNF-SD-WM-ER-716, Rev. 0, as amended, SGN Eurisys Services Corporation for Fluor Daniel Hanford, Inc., Richland, Washington.

Place, D. E., 1997f, Preliminary Tank Characterization Report for Single-Shell

Tank 241-TX-114: Best-Basis Inventory, HNF-SD-WM-ER-708, Rev. 0, as amended, Lockheed Martin Hanford Corporation for Fluor Daniel Hanford, Inc., Richland, Washington.

Place, D. E., 1997g, Preliminary Tank Characterization Report for Single-Shell Tank 241-TX-116: Best-Basis Inventory, HNF-SD-WM-ER-705, Rev. 0, as amended, SGN Eurisys Services Corporation for Fluor Daniel Hanford, Inc., Richland, Washington.

Place, D. E., 1997h, Preliminary Tank Characterization Report for Single-Shell Tank 241-TX-117: Best-Basis Inventory, HNF-SD-WM-ER-711, Rev. 0, as amended, SGN Eurisys Services Corporation for Fluor Daniel Hanford, Inc., Richland, Washington.

Place, D. E., 1997i, Preliminary Tank Characterization Report for Single-Shell Tank 241-TY-102: Best-Basis Inventory, HNF-SD-WM-ER-719, Rev. 0, as amended, SGN Eurisys Services Corporation for Fluor Daniel Hanford, Inc., Richland, Washington.

Raphael, G. F., and T. T. Tran, 1995, Tank Characterization Report for Single-Shell Tank 241-U-204, WHC-SD-WM-ER-486, Rev. 0, as amended, Westinghouse Hanford Company, Richland, Washington.

Rasmussen, J. H. E., S. R. Wilmarth, and L. J. Fergestrom, 1998, Tank Characterization Report for Single-Shell Tank 241-BX-110, HNF-SD-WM-ER-566, Rev. 1, Fluor Daniel Hanford, Inc., Richland, Washington.

Rollosson, D. I., L. C. Amato, N. L. Hulse, and S. R. Wilmarth, 1999, Tank Characterization Report for Double-Shell Tank 241-AN-102, HNF-SD-WM-ER-545, Rev. 2, Lockheed Martin Hanford Corporation for Fluor Daniel Hanford, Inc., Richland, Washington.

Ryan, G. W., 1995a, Tank Characterization Report for Double-Shell Tank 241-AY-102, WHC-SD-WM-ER-454, Rev. 0, as amended, Westinghouse Hanford Company, Richland, Washington.

Ryan, G. W., 1995b, Tank Characterization Report for Double-Shell Tank 241-AZ-102, WHC-SD-WM-ER-411, Rev. 0, as amended, Westinghouse Hanford Company, Richland, Washington. 


\section{Tank Characterization Reports}

Ryan, G. W., 1995c, Tank Characterization Report for Single-Shell Tank 241-TY-104, WHC-SD-WM-ER-481, Rev. 0, as amended, Westinghouse Hanford Company, Richland, Washington.

Sasaki, L. M., J. G. Douglas, R. H. Stephens, L. C. Amato, and T. T. Tran, 1996a, Tank Characterization Report for Single-Shell Tank 241-B-204, WHC-SD-WM-ER-581, Rev. 0, as amended, Westinghouse Hanford Company, Richland, Washington.

Sasaki, L. M., J. G. Field, L. C. Amato, J. L. Stroup, 1996b, Tank Characterization Report for Single-Shell Tank 241-TX-107, WHC-SD-WM-ER-584, Rev. 0, as amended, Westinghouse Hanford Company, Richland, Washington.

Sasaki, L. M., T. T. Tran, L. C. Amato, G. P. Westleigh, and J. L. Stroup, 1996c, Tank Characterization Report for Single-Shell Tank 241-BX-106, WHC-SD-WM-ER-570, Rev. 0, as amended, Westinghouse Hanford Company, Richland, Washington.

Sasaki, L. M., J. D. Franklin, J. L. Stroup, L. Jensen, and R. T. Winward, 1997a, Tank Characterization Report for Single-Shell Tank 241-T-104, HNF-SD-WM-ER-372, Rev. 1, as amended, Lockheed Martin Hanford Corporation for Fluor Daniel Hanford, Inc., Richland, Washington.

Sasaki, L. M., M. J. Kupfer, L. C. Amato, B. J. Morris, J. L. Stroup, R. D. Cromar, R. T. Winward, 1997b, Tank Characterization Report for Single-Shell Tank 241-BY-102, HNF-SD-WM-ER-630, Rev. 0, as amended, Lockheed Martin Hanford Corporation for Fluor Daniel Hanford, Inc., Richland, Washington.

Sasaki, L. M., J. A. Lechelt, N. L. Hulse, and S. R. Wilmarth, 1997c, Tank Characterization Report for Single-Shell Tank 241-T-107, HNF-SD-WM-ER-382, Rev. 1, as amended, Lockheed Martin Hanford Corporation for Fluor Daniel Hanford, Inc., Richland, Washington.

Sasaki, L. M., S. R. Wilmarth, and C. J. Lindquist. 1998, Tank Characterization Report for Double-Shell Tank 241-AW-105, HNF-SD-WM-ER-364, Rev. 2, Lockheed Martin Hanford Corporation for Fluor Daniel Hanford Inc., Richland, Washington.

Schreiber, R. D., 1996, Tank Characterization Report for Single-Shell Tank 241-C-106, WHC-SD-WM-ER-645, Rev. 0, as amended, Westinghouse Hanford Company, Richland, Washington.

Schreiber, R. D., 1997, Tank Characterization Report for Single-Shell Tank 241-B-108, HNF-SD-WM-ER-674, Rev. 0, prepared by Lockheed Martin Hanford Corporation for Fluor Daniel Hanford, Inc., Richland, Washington. 


\section{Tank Characterization Reports}

Schreiber, R. D., J.G. Kristofzski, J. D. Matheson, M. W. Urie, and T. T. Tran, 1995a, Tank Characterization Report for Single-Shell Tank 241-U-203, WHC-SD-WM-ER-485, Rev. 0, as amended, Westinghouse Hanford Company, Richland, Washington.

Schreiber, R. D., J. G. Kristofzski, M. W. Urie, and T. T. Tran, 1995b, Tank Characterization Report for Single-Shell Tank 241-U-201, WHC-SD-WM-ER-483, Rev. 0, as amended, Westinghouse Hanford Company, Richland, Washington.

Schreiber, R. D., J. G. Douglas, R. D. Cromar, T. L. Welsh, B. C. Simpson, L. J. Fergestrom, and R. M. Ozanich, 1996a, Tank Characterization Report for Single-Shell Tank 241-C-106, Rev. 0, Westinghouse Hanford Company, Richland, Washington.

Schreiber, R. D., J. G. Douglas, and T. T. Tran, 1996b, Tank Characterization Report for Single-Shell Tank 241-B-101, WHC-SD-WM-ER-528, Rev. 0, as amended, Westinghouse Hanford Company, Richland, Washington.

Sederburg, J. P., 1995a, Tank Characterization Report for Single-Shell Tank 241-AX-102, WHC-SD-WM-ER-472, Rev. 0, Westinghouse Hanford Company, Richland, Washington.

Sederburg, J. P., 1995b, Tank Characterization Report for Single-Shell Tank 241-BX-108, WHC-SD-WM-ER-407, Rev. 0, Westinghouse Hanford Company, Richland, Washington.

Sederburg, J. P., 1995c, Tank Characterization Report for Single-Shell Tank 241-C-108, WHC-SD-WM-ER-503, Rev. 0, as amended, Westinghouse Hanford Company, Richland, Washington.

Simpson, B. C., 1998, Tank Characterization Report for Single-Shell Tanks 241-T-201, -T-202, $-T-203$, and $-T-204, \mathrm{HNF}-1501$, Rev. 0, as amended, Lockheed Martin Hanford Corporation for Fluor Daniel Hanford, Inc., Richland, Washington.

Simpson, B. C., G. S. Anderson, S. A. Hartley, J. G. Hill, M. M. King, A. T. DiCenso, and J. L. Stroup, 1995, Tank Characterization Report for Single-Shell Tank 241-C-111, WHC-SD-WM-ER-475, Rev. 0, as amended, Westinghouse Hanford Company, Richland, Washington.

Simpson, B. C., R. D. Cromar, and R. D. Schreiber, 1996a, Tank Characterization Report for Single-Shell Tank 241-BY-110, WHC-SD-WM-ER-591, Rev. 0, as amended, Westinghouse Hanford Company, Richland, Washington.

Simpson, B. C., J. G. Field, D. W. Engel, D. S. Daly, 1996b, Tank Characterization Report for Single-Shell Tank 241-S-107, WHC-SD-WM-ER-589, Rev. 0, as amended, Westinghouse Hanford Company, Richland, Washington. 


\section{Tank Characterization Reports}

Simpson, B. C., B. Morris, R. D. Cromar, R. E. Stoudt, and J. L. Stroup, 1997a, Tank Characterization Report for Single-Shell Tank 241-C-109, HNF-SD-WM-ER-402, Rev. 1, as amended, Lockheed Martin Hanford Corporation for Fluor Daniel Hanford, Inc., Richland, Washington.

Simpson, B. C., L. Parkhill, R. D. Cromar, J. L. Stroup, R. E. Stout, 1997b, Tank Characterization Report for Single-Shell Tank 241-C-112, HNF-SD-WM-ER-541, Rev. 1, as amended, Lockheed Martin Hanford Corporation for Fluor Daniel Hanford, Inc., Richland, Washington.

Stephens, R. H., 1997, Tank Characterization Report for Single-Shell Tank 241-U-110, HNF-SD-WM-ER-551, Rev. 1, as amended, Lockheed Martin Hanford Corporation for Fluor Daniel Hanford Inc., Richland, Washington.

Thompson, R. R. and R. H. Stephens, 1996, Tank Characterization Report for Double-Shell Tank 241-AY-101, WHC-SD-WM-ER-605, Rev. 0, as amended, Westinghouse Hanford Company, Richland, Washington.

Thompson, R. R., L. W. Shelton, R. H. Stephens, and T. L. Welsh, 1997, Tank Characterization Report for Double-Shell Tank 241-AP-106, HNF-SD-WM-ER-361, Rev. 1, as amended, Lockheed Martin Hanford Corporation for Fluor Daniel Hanford Inc., Richland, Washington.

Tusler, L. A., L. C. Amato, and T. T. Tran, 1995, Tcink Characterization Report for Single-Shell Tank 241-C-105, WHC-SD-WM-ER-489, Rev. 0, Westinghouse Hanford Company, Richland, Washington.

Wilkins, N. E., J. G. Field, L. W. Shelton, and T. L. Welsh, 1997, Tank Characterization Report for Double-Shell Tank 241-AN-103, HNF-SD-WM-ER-702, Rev. 0, Lockheed Martin Hanford Corporation for Fluor Daniel Hanford, Inc., Richland, Washington.

Winkelman, W. D., and J. A. Franklin, 1996, Tank Characterization Report for Double-Shell Tank 241-AP-104, WHC-SD-WM-ER-596, Rev. 0, Westinghouse Hanford Company, Richland, Washington.

Winkelman, W. D. and B. J. Morris, 1996, Tank Characterization Report for Single-Shell Tank 241-BX-112, WHC-SD-WM-ER-602, Rev. 0, as amended, Westinghouse Hanford Company, Richland, Washington.

Winkelman, W. D., B. J. Morris, and K. M. Hodgson, 1997, Tank Characterization Report for Single-Shell Tank 241-BX-107, HNF-SD-WM-ER-539, Rev. 1, prepared by Lockheed Martin Hanford Corporation for Fluor Daniel Hanford, Inc., Richland, Washington. 


\section{Tank Characterization Reports}

Winters, W. I., K. E. Bell, R. H. Stephens, L. C. Amato, and T. T. Tran, 1996, Tank Characterization Report for Single-Shell Tank 241-C-103, WHC-SD-WM-ER-558, Rev. 0, as amended, Westinghouse Hanford Company, Richland, Washington.

\section{7.

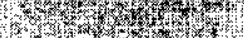

CHG, 2000, System Specification for the Double-Shell Tank System, HNF-SD-WM-TRD-007, Rev. 0, Numatec Hanford Corporation for CH2M HILL Hanford Group, Inc., Richland, Washington.

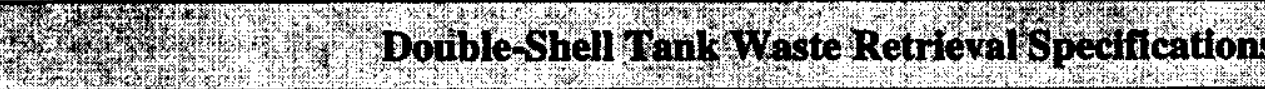

CHG, 2000, Double-Shell Tank Diluent and Flush Subsystem Specification, HNF-4163, Rev. 0, Numatec Hanford Corporation for CH2M HILL Hanford Group, Inc., Richland, Washington.

CHG, 2000, Double-Shell Tank Maintenance and Recovery Subsystem Definition Report, HNF-4159, Rev. 0, Numatec Hanford Corporation for CH2M HILL Hanford Group, Inc., Richland, Washington.

CHG, 2000, Double-Shell Tank Mixer Pump Subsystem Specification, HNF-4164, Rev. 0, Numatec Hanford Corporation for CH2M HILL Hanford Group, Inc., Richland, Washington.

CHG, 2000, Double-Shell Tank Monitor and Control Subsystem, HNF-4155, Rev. 0, Numatec Hanford Corporation for CH2M HILL Hanford Group, Inc., Richland, Washington.

CHG, 2000, Double-Shell Tank Process Waste Sampling Subsystem Specification, HNF-4154, Rev. 0, Numatec Hanford Corporation for CH2M HILL Hanford Group, Inc., Richland, Washington.

CHG, 2000, Double-Shell Tank Transfer Piping Subsystem Specification, HNF-4161, Rev. 0, Numatec Hanford Corporation for CH2M HILL Hanford Group, Inc., Richland, Washington.

CHG, 2000, Double-Shell Tank Transfer Pump Subsystem Specification, HNF-4162, Rev. 0, Numatec Hanford Corporation for CH2M HILL Hanford Group, Inc., Richland, Washington. 


\section{Double-Shell Tank Waste Retrieval Specinications}

CHG, 2000, Double-Shell Tank Transfer Valving Subsystem Specification, HNF-4160, Rev. 0, Numatec Hanford Corporation for CH2M HILL Hanford Group, Inc., Richland, Washington.

CHG, 2000, Double-Shell Tank Utilities Subsystem Specification, HNF-4157, Rev. 0, Numatec Hanford Corporation for CH2M HILL Hanford Group, Inc., Richland, Washington.

CHG, 2000, Double-Shell Tank Ventilation Subsystem Specification, HNF-5196, Rev. 0, Numatec Hanford Corporation for CH2M HILL Hanford Group, Inc., Richland, Washington.

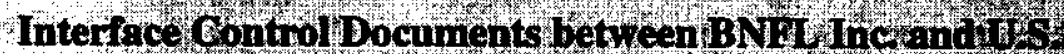

BNFL, 2000, Interface Control Document for Raw Water, BNFL-5193-ID-01, Rev. 4, as amended, BNFL Inc., Richland, Washington.

BNFL, 2000, Interface Control Document for Potable Water, BNFL-5193-ID-02, Rev. 4, as amended, BNFL Inc., Richland, Washington.

BNFL, 2000, Interface Control Document for Radioactive Solid Waste, BNFL-5193-ID-03, Rev. 5, as amended, BNFL Inc., Richland, Washington.

BNFL, 2000, Interface Control Document for Dangerous Waste, BNFL-5193-ID-04, Rev. 3, as amended, BNFL Inc., Richland, Washington.

BNFL, 2000, Interface Control Document for Nonradioactive, Nondangerous Liquid Effluents, BNFL-5193-ID-05, Rev. 4, as amended, BNFL Inc., Richland, Washington.

BNFL, 2000, Interface Control Document for Radioactive, Dangerous Liquid Effluents, BNFL-5193-ID-06, Rev. 4, as amended, BNFL Inc., Richland, Washington.

BNFL, 2000, Interface Control Document for Nondangerous Solid Waste, BNFL-5193-ID-07, Rev. 3, as amended, BNFL Inc., Richland, Washington.

BNFL, 2000, Interface Control Document for Liquid Sanitary Waste, BNFL-5193-ID-08, Rev. 3, as amended, BNFL Inc., Richland, Washington.

BNFL, 2000, Interface Control Document for Land for Siting, BNFL-5193-ID-09, Rev.4, as amended, BNFL Inc., Richland, Washington.

BNFL, 2000, Interface Control Document for Deactivated Facility and Site, BNFL-5193-ID-10, Rev. 3, as amended, BNFL Inc., Richland, Washington. 
Interface Control Documents between BNFL Inc. and U.S. Department of Energy

BNFL, 2000, Interface Control Document for Electricity, BNFL-5193-ID-11, Rev. 4, as amended, BNFL Inc., Richland, Washington.

BNFL, 2000, Interface Control Document for Roads, BNFL-5193-ID-12, as amended, Rev. 4, BNFL Inc., Richland, Washington.

BNFL, 2000, Interface Control Document for Immobilized High-Level Waste, BNFL-5193-ID-14, Rev. 4, as amended, Draft, BNFL Inc., Richland, Washington.

BNFL, 2000, Interface Control Document for Immobilized Low-Activity Waste, BNFL-5193-ID-15, Rev. 4, as amended, Draft, BNFL Inc., Richland, Washington.

BNFL, 2000, Interface Control Document for Entrained Solids, BNFL-5193-ID-16, Rev. 3, BNFL Inc., Richland, Washington.

BNFL, 2000, Interface Control Document for Low-Activity Waste Feed, BNFL-5193-ID-19, Rev. 4, as amended, BNFL Inc., Richland, Washington.

BNFL, 2000, Interface Control Document for High-Level Waste Feed, BNFL-5193-ID-20, Rev. 4, as amended, BNFL Inc., Richland, Washington.

BNFL, 2000, Interface Control Document for Air Emissions, BNFL-5193-ID-22, Rev. 3, as amended, BNFL Inc., Richland, Washington.

BNFL, 2000, Interface Control Document for Waste Treatability Samples, BNFL-5193-ID-23, Rev. 3, as amended, BNFL Inc., Richland, Washington.

BNFL, 2000, Interface Control Document for Emergency Response, BNFL-5193-ID-25, Rev. 3, as amended, BNFL Inc., Richland, Washington.

BNFL, 2000, Interface Control Document for Permitting, BNFL-5193-ID-26, Rev. 3, as amended, BNFL Inc., Richland, Washington.

\section{Documents}

Alm, A. L., 1996, "Approval of Critical Decisions for Phase 1 Immobilized High-Level and Low-Activity Waste Interim Storage and Tank Farm Restoration and Safe Operations Projects (Projects W-464, W-465, and W-314)," (letter to J. Wagoner, Manager, U.S. Department of Energy, Richland Operations Office, Richland, Washington, December 26), U.S. Department of Energy, Washington, D.C. 


\section{Documents}

Ashworth, S. C., and D. A. Burbank, 1998, Design Requirements Document for Project W-520, Immobilized Low-Activity Waste Disposal, HNF-2211, Rev. 0, COGEMA Engineering Corporation, Richland, Washington.

Bailey, J. W., 1998a, Functional Design Criteria for Tank 241-C-106 Waste Retrieval, Project W-320, HNF-SD-W320-FDC-001, Rev. 5, Numatec Hanford Corporation for Fluor Daniel Hanford, Inc., Richland, Washington.

Bailey, J. W., 1998b, Project W-320, 241-C-106 Sluicing, Master Calculation List, HNF-2527, Rev. 0, Numatec Hanford Corporation for Fluor Daniel Hanford, Inc., Richland, Washington.

Bailey, J. W., 1998c, Project W-320, 241-C-106 Waste Retrieval Spare Parts List, HNF-2404, Rev. 1, Numatec Hanford Corporation for Fluor Daniel Hanford, Inc., Richland, Washington.

Bailey, J. W., and R. R. Bevins, 1997, Preliminary Engineering Analysis for Safety Class and Safety Significant WRSS Equipment, HNF-1559, Rev. 2, Numatec Hanford Corporation for Fluor Daniel Hanford, Inc., Richland, Washington.

Bauer, J. D., 1994a, Notice of Construction Application Pursuant to Washington Administrative Code 173-460 for Ventilation Upgrades, 241-AY and 241-AZ Tank Farms, (Correspondence 9400853 to J. Stohr, Washington Department of Ecology, March 2), U.S. Department of Energy, Richland Operations Office, Richland, Washington.

Bauer, J. D., 1994b, Notice of Construction Application Pursuant to Washington Administrative Code 246-247 for Ventilation Upgrades, 241-AY and 241-AZ Tank Farms, (Correspondence 9400852 to A. W. Conklin, Washington Department of Health, March 2), U.S. Department of Energy, Richland Operations Office, Richland, Washington.

Bevins, R. R., 1997, Severe Environmental Qualification and Life Expectancy of Immersible Pump System, HNF-SD-W320-ER-005, Rev. 0, Numatec Hanford Corporation for Fluor Daniel Hanford, Inc., Richland, Washington.

Bevins, R. R., 1998, Project W-320, Tank 241-C-106 Waste Retrieval Sluicing System Testing Plan, WHC-SD-W320-TP-001, Rev. 1, Westinghouse Hanford Company, Richland, Washington.

Boes, K. A., 1996a, Conceptual Design Report for Tank Farm Restoration and Safe Operations, Project W-314, WHC-SD-W314-CDR-001, Rev. 1, Fluor Daniel Hanford, Inc., Richland, Washington. 


\section{Documents}

Boes, K. A., 1996b, Preliminary Design Requirements Document for Project W-314, Tank Farm Restoration and Safe Operations, WHC-SD-W314-DRD-001, Rev. 1, Westinghouse Hanford Company, Richland, Washington.

Bourger, F. H., 1994, Hazard Categorization Report for the 200 Area Effluent Treatment Facility, WHC-SD-C018H-HC-002, Rev. 0, Westinghouse Hanford Company, Richland, Washington.

Bourger, F. H., and J. C. Conner, 1992, Preliminary Safety Analysis Report for Project W151, Tank 241-AZ-101 Waste Retrieval System, WHC-SD-W151-PSAR-001, Rev. 0, Westinghouse Hanford Company, Richland, Washington.

Bowman, T. J., 1999, Acceptance Test Procedure for Cathodic Protection, Rectifier 31 , WHC-SD-W030-ATP-001, Rev. 1, Fluor Daniel Hanford, Inc., Richland, Washington.

Brantley, W. M., 1996, Functional Design Criteria for Project W-058, Replacement of the Cross-Site Transfer System, WHC-SD-W058-FDC-001, Rev. 4, Westinghouse Hanford Company, Richland, Washington.

Burbank, D. A., 1996, Alternatives Generation and Analysis Report for Immobilized LowActivity Waste Interim Storage Architecture, WHC-SD-W465-AGA-001, Rev. 0, Westinghouse Hanford Company, Richland, Washington.

Burbank, D. A., 1999, River Protection Project Immobilized Low-Activity Waste Disposal Plan, HNF-1517, Rev. 1, Lockheed Martin Hanford Corporation for Fluor Daniel Hanford, Inc., Richland, Washington.

Burgard, K. C., 1998, Conceptual Design Report for Immobilized High-Level Waste Interim Storage Facility (Phase 1), HNF-2298, Rev. 1, Fluor Daniel Hanford, Inc., Richland, Washington.

Calmus, R. B., 1996a, Design Requirements Document for Interim Store Phase I Solidified High-Level Waste, Function 4.2.4.1.2, WHC-SD-WM-DRD-012, Rev. 0, Westinghouse Hanford Company, Richland, Washington.

Calmus, R. B., 1996b, HLW Interim Storage Architecture Selection - Decision Report, WHC-SD-WM-TA-183, Rev. 0, Westinghouse Hanford Company, Richland, Washington.

Calmus, R. B., 1999, River Protection Project Immobilized High-Level Waste Interim Storage Plan, HNF-1751, Rev. 1, Lockheed Martin Hanford Corporation for Fluor Daniel Hanford, Inc., Richland, Washington. 


\section{Documents}

Calmus, R. B., and J. R. Barker, 1999, Immobilized High-Level Waste Interim Storage Alternatives Generation and Analysis Decision Report, HNF-3899, Rev. 0, as amended, Fluor Daniel Hanford, Inc., Richland, Washington.

Campbell, T. A., 1998, 242-A Evaporator Safety Analysis Report, HNF-SD-WM-SAR-023, Rev. 3, Waste Management Federal Services Hanford, Inc., for Fluor Daniel Hanford, Inc., Richland, Washington.

Campbell, T. A., 2000, 200 Area Effluent Treatment Facility Auditable Safety Analysis Report, HNF-SD-ETF-ASA-001, Rev. 4, Fluor Hanford, Inc., for CH2M HILL Hanford Group, Inc., Richland, Washington.

Carlson, A. B., P. J. Certa, A. A. Dykes, J. K. Liming, B. K. Olson, J. G. Stampelos, and M. M. Jennings, 1999, Waste Feed Delivery Technical Basis, Volume IV Waste Feed Delivery Operations and Maintenance Concept, HNF-1939, Vol. IV, Rev. 0, Fluor Daniel Hanford, Inc., Richland, Washington.

Carothers, K. G., S. D. Estey, N. W. Kirch, L. A., Stauffer, and J. W. Bailey 1999, Tank 241-C-106 Waste Retrieval Sluicing System Process Control Plan, HNF-SD-WM-PCP-013, Rev. 2, as amended Lockheed Martin Hanford Corporation for Fluor Daniel Hanford, Inc., Richland, Washington.

Castleberry, J. L., 1998, Spare Parts List W-030 Tank Farm Ventilation Upgrade, HNF-1759, Rev. 1, Lockheed Martin Hanford Corporation for Fluor Daniel Hanford, Inc., Richland, Washington.

CHG, 2000a, Integrated Environment, Safety, and Health Management System Description for the Tank Farm Contractor, RPP-MP-003, Rev. 1, CH2M HILL Hanford Group, Inc., Richland, Washington.

CHG, 2000b, RPP Administration, HNF-IP-0842, CH2M HILL Hanford Group, Inc., Richland, Washington.

CHG, 2000c, Tank Waste Remediation System Final Safety Analysis Report, HNF-SD-WM-SAR-067, Rev. 1, as amended, CH2M HILL Hanford Group, Inc., Richland, Washington.

CHG, 2000d, Tank Waste Remediation System Technical Safety Requirements, HNF-SD-WM-TSR-006, Rev. 1, as amended, CH2M HILL Hanford Group, Inc., Richland, Washington.

Claghorn, R. D., 1997, Decision Document for the Final Disposition of Cesium and Strontium Capsules, HNF-SD-WM-RPT-294, Rev. 0, Numatec Hanford Corporation for Fluor Daniel Hanford, Inc., Richland, Washington. 


\section{Documents}

Claghorn, R. D., 1998, Performance Requirements for the Double-Shell Tank System: Phase 1, HNF-2168, Rev. 0, Numatec Hanford Corporation for Fluor Daniel Hanford, Inc., Richland, Washington.

Clifton, F. T., 1994, Project W030 Final Review Report, WHC-SD-W030-DRR-005, Rev. 0, Westinghouse Hanford Company, Richland, Washington.

Clifton, F. T., 1995a, Acceptance Test Procedure for Cathodic Protection, Rectifier 11, WHC-SD-W030-ATP-003, Rev. 0, Westinghouse Hanford Company, Richland, Washington.

Clifton, F. T., 1995b, Acceptance Test Procedure for Cathodic Protection, Rectifier 41, WHC-SD-W030-ATP-002, Rev. 0, Westinghouse Hanford Company, Richland, Washington.

Clifton, F. T., 1996a, Acceptance Test Procedure - Tank Farm and Miscellaneous Instrumentation, WHC-SD-W030-ATP-004, Rev. 0, Westinghouse Hanford Company, Richland, Washington.

Clifton, F. T., 1996b, Acceptance Test Procedure - Tank Farm Ventilation Upgrade W030; Primary Vent Filter Train, WHC-SD-W030-ATP-006, Rev. 0, Westinghouse Hanford Company, Richland, Washington.

Coleman, L., J. Colgan, W. Cox, B. Crea, P. Powell, and R. Webb, 1997, Tank Farms Operations Administrative Controls, HNF-IP-1266, Rev. 1, as amended, Lockheed Martin Hanford Corporation for Fluor Daniel Hanford, Inc.

This document is revised uniquely in that certain sections have revision numbers yet the document has no overall revision. It is available on the internet at http://aptfpg02.rl.gov/1266_Procedures/1266.htm.

Colosi, K. A., 1995, Acceptance Test Procedure Backup Power System, WHC-SD-W030-ATP-007, Rev. 0, Westinghouse Hanford Company, Richland, Washington.

Crane, A. F., 1998, 200 Area Treated Effluent Disposal Facility Interface Control, HNF-SD-W049H-ICD-001, Rev. 5, Rust Federal Services Hanford, Inc., for Fluor Daniel Hanford, Inc., Richland, Washington.

Crass, D. W., 1996a, W-151 Steam Coil Fatigue Analysis for Mixer Pump Jet Loads, WHC-SD-W151-DA-006, Rev. 0, Westinghouse Hanford Company, Richland, Washington. 


\section{Documents}

Crass, D. W., 1996b, W-151 Transfer Pump Stress Analysis for Mixer Pump Jet Loads, WHC-SD-W151-DA-007, Rev. 0, Westinghouse Hanford Company, Richland, Washington.

Crass, D. W., 1997, Formal Design Review Report Project W-151 Mixer Pump Procurement, HNF-SD-W151-DRR-002, Rev. 0, Lockheed Martin Hanford Corporation for Fluor Daniel Hanford, Inc., Richland, Washington.

Dallas, M. D., 1997, FY 2000 Annual Work Plan for Infrastructure Programs WBS 6.2, HNF-SP-1 169-98, Rev. 2, DynCorp Tri-Cities Services, Inc., for Fluor Daniel Hanford, Inc., Richland, Washington.

Deffenbaugh, M. L., 1996, "Environmental Requirements Checklist for the High-Level Waste Storage Project Canister Storage Building," (letter 70100-96-004 to K. C. Burgard, November 4), Lockheed Martin Hanford Corporation, Richland, Washington.

Deffenbaugh, M. L., 1998, Environmental Permits and Approvals Plan for High-Level Waste Interim Storage, Project W-464, HNF-SD-ENV-EE-002, Rev. 1, Lockheed Martin Hanford Corporation for Fluor Daniel Hanford, Inc., Richland, Washington.

Deffenbaugh, M. L., J. D. Guberski, C. J. Grando, V. L. Armstrong, J. E. Mercado, and M. W. Cline, 1997, Permitting Plan for the Immobilized Low-Activity Waste Project, HNF-SD-ENV-EE-003, Rev. 0, Lockheed Martin Hanford Corporation for Fluor Daniel Hanford, Inc., Richland Washington.

Dexter, M. L., 1999, RPP Environmental Permits and Related Documentation, HNF-4474, Rev. 4, CH2M HILL Hanford Group, Inc., Richland, Washington.

DOE, 1996, Waste Acceptance - Systems Requirements Document, DOE/RW-0351P, Rev. 2, U.S. Department of Energy, Washington, D.C.

DOE and Ecology, 1996, Tank Waste Remediation System, Hanford Site, Richland, Washington, Final Environmental Impact Statement, DOE/EIS-0189, Washington State Department of Ecology, Olympia, Washington, and U.S. Department of Energy, Washington, D.C.

Domnoske-Rauch, L. A., 2000, Tank Farms Essential Drawing Plan, HNF-SD-WM-PC-002, Rev. 12, CH2M HILL Hanford Group, Inc., Richland, Washington.

Duncan, D. R., 1995, Interface Control Document Between the Tank Waste Remediation System and the Solid Waste Disposal Division, WHC-SD-WM-PICD-003, Rev. 0, Westinghouse Hanford Company, Richland, Washington.

Dykes, A. A., J. K. Liming, B. K. Olson, 1999, Waste Feed Delivery System Phase I Preliminary Reliability, Availability, Maintainability Analysis, HNF-2863, Rev. 1, Numatec Hanford Corporation for Lockheed Martin Hanford Corporation, Richland, Washington. 


\section{Documents}

Ecology, EPA, and DOE, 1996, Hanford Federal Facility Agreement and Consent Order,

2 vols., Washington State Department of Ecology, Olympia, Washington;

U.S. Environmental Protection Agency, Washington, D.C.; and U.S. Department of Energy, Washington, D.C.

FDH, 1998, Hanford Site Solid Waste Acceptance Criteria, HNF-EP-0063, Rev. 5, Fluor Daniel Hanford, Inc., Richland, Washington.

FDH, 1999, Solid Waste Integrated Forecast Technical (SWIFT) Report: FY 2000 to FY 2046, HNF-EP-0918, Rev. 6, Fluor Daniel Hanford, Inc., Richland, Washington.

Galbraith, J. D., and P. M. Daling (PNNL), 1997, Decision Document: Phase 1 Intermediate Waste Feed Staging System Design Requirements, HNF-SD-WM-TI-800, Rev. 0, Numatec Hanford Corporation for Fluor Daniel Hanford, Inc., Richland, Washington.

Galioto, T. M., 1997a, 242AL Liquid Effluent Retention Facility Auditable Safety Analysis, HNF-SD-LEF-ASA-002, Rev. 1, as amended, Fluor Daniel Hanford, Inc., Richland, Washington.

Galioto, T. M., 1997b, Liquid Effluent Retention Facility Final Hazard Category Determination, HNF-SD-WM-SAD-040, Rev. 1, Fluor Daniel Hanford, Inc., Richland, Washington.

Gilbert, J. L., 1998, Acceptance for Beneficial Use, Project W-058, HNF-SD-W058-ABU-001, Rev. 1, Numatec Hanford Corporation for Fluor Daniel Hanford, Inc., Richland, Washington.

Graves, C. E., 1998, Design Basis Document, Project W-320, Tank 241-C-106, Sluicing Project Rebaselining Change Request New Scope, HNF-SD-W320-DB-001, Rev. 2, Numatec Hanford Corporation for Fluor Daniel Hanford, Inc., Richland, Washington.

Halverson, T. G., 2000, Draft Project Execution Plan for the Tank Farm Contractor, RPP-6017, Rev. 0, CH2M HILL Hanford Group, Inc., Richland, Washington.

Hammers, J. S., 1999a, Project W-314 241-AN-A Valve Pit Upgrade Acceptance for Beneficial Use, HNF-SD-W314-ABU-002, Rev. 0, Numatec Hanford Corporation for Lockheed Martin Hanford Corporation, Richland, Washington.

Hammers, J. S., 1999b, Project W-314 241-AN-B Valve Pit Upgrade Acceptance for Beneficial Use, HNF-SD-W314-ABU-003, Rev. 2, as amended, Numatec Hanford Corporation for Lockheed Martin Hanford Corporation, Richland, Washington.

Hammers, J. S., 1999c, Project W-314 Specific Test and Evaluation Plan 24I-AN-A Valve Pit, HNF-1733, Rev. 4, as amended, Numatec Hanford Corporation for Lockheed Martin Hanford Corporation, Richland, Washington. 


\section{Documents}

Hammers, J. S., 1999d, Test and Evaluation Plan for Project W-314 Tank Farm Restoration and Safe Operation, HNF-SD-W314-TEP-001, Rev. 3, Numatec Hanford Corporation for Lockheed Martin Hanford Corporation, Richland, Washington.

Hanson, C. A., 1996, Memorandum of Agreement (MOA) - Utilization of Canister Storage Building (CSB) Vaults 2 and 3 for Immobilized High-Level Tank Waste, (memorandum 96-SFD-104 to Jackson Kinzer, Assistant Manager, Office of Tank Waste Remediation System, April 18), U.S. Department of Energy, Richland Operations Office, Richland, Washington.

Harris, J. P. III, 2000, River Protection Project Double-Shell Tank Waste Retrieval Authorization Basis Amendment Task Plan, HNF-1722, Rev. 2, CH2M HILL Hanford Group, Inc., Richland, Washington.

Hecht, S. L., 2000, Preliminary Heat Transfer Studies for the DST Transfer Piping, HNF-5442, Rev. 0, prepared by Fluor Hanford Corporation for CH2M HILL Hanford Group, Inc., Richland, Washington.

Hill, L. F., 1995, Acceptance Test Procedure for W030 Monitor and Control System Software, WHC-SD-W030-ATP-011, Rev. 0, Westinghouse Hanford Company, Richland, Washington.

Jacobs, E. R., 1996, "Final CSB High-Level Waste Supplemental Report," (letter FRF049 to J. J. Jones, Westinghouse Hanford Company, September 19), Fluor Daniel, Inc., Richland, Washington.

Jacobson, R. W., 1997, Alternative Generation and Analysis Report, Tank Farm Monitoring and Master Pump Shutdown, Tank Farm Restoration and Safe Operation, W-314, HNF-SD-W314-AGA-007, Rev. 0, Lockheed Martin Hanford Corporation for Fluor Daniel Hanford, Inc., Richland, Washington.

Julyk, L. J., 1997, Evaluation of the Effect of Project W-151 Mixer Pump Jets on In-Tank Equipment Considering Potential Sludge Buildup on Equipment in Waste Tank 241-AZ-101, Hanford Site, Richland, Washington, HNF-SD-W151-DA-008, Rev. 0, Fluor Daniel Northwest, Inc., for Fluor Daniel Hanford, Inc., Richland, Washington.

Keller, C. M., 1997, Functional Design Criteria for the Tank Farm Ventilation Upgrade, Project W-030, HNF-SD-600-FDC-001, Rev. 4, Numatec Hanford Corporation for Fluor Daniel Hanford, Inc., Richland, Washington.

Kidder, R. J., 1996, Replacement of the Cross-Site Transfer System Preliminary Safety Analysis Report, WHC-SD-W058-PSAR-001, Rev.1, Westinghouse Hanford Company, Richland, Washington. 
HNF-1901 REV 2

\section{Documents}

Kirkbride, R. A., 2000, Tank Farm Contractor Operation and Utilization Plan, HNF-SD-WM-SP-012, Rev. 2, CH2M HILL Hanford Group, Inc., Richland, Washington.

Kohlman, E. H., 1993, Project W-151 Supplemental Design Requirements, WHC-SD-W151-SDRD-001, Rev. 0, Westinghouse Hanford Company, Richland, Washington.

Kupfer, M. J., A. L. Boldt, B. A. Higley, K. M. Hodgson, L. W. Shelton, B. C. Simpson, R. A. Watrous, S. L. Lambert, D. E. Place, R. M. Orme, G. L. Borsheim, N. G. Colton, M. D. LeClair, R. T. Winward, and W. W. Schulz, 1997, Standard Inventories of Chemicals and Radionuclides in Hanford Site Tank Wastes, HNF-SD-WM-TI-740, Rev. 0, as amended, prepared by Lockheed Martin Hanford Corporation for Fluor Daniel Hanford, Inc., Richland, Washington.

Lambert, D. L., 1990, Tank 101-AZ Waste Retrieval System Project W-151, WHC-SD-W151-CDR-001, Rev. 0, Westinghouse Hanford Company, Richland, Washington.

Leonard, M. W., 2000, Engineering-Basis Document Review Supporting Double-Shell Tank System Specification, HNF-3350, Rev. 0, CH2M HILL Hanford Group, Inc., Richland, Washington.

LMHC, 1999a, Agreement in Principle Between Lockheed Martin Hanford Corporation and DynCorp Tri-Cities Services, Inc., Updated for Fiscal Year 2000, Lockheed Martin Hanford Corporation, Richland, Washington.

LMHC, 1999b, Agreement in Principle Between Lockheed Martin Hanford Corporation and Waste Management Federal Services of Hanford, Inc., Updated for Fiscal Year 2000, Lockheed Martin Hanford Corporation, Richland, Washington.

Mann, F. M., C. R. Eiholzer, Y. Chen, N. W. Kline, A. H. Lu, B. P. McGrail, and P. D. Rittmann, 1997, Hanford Low-Level Tank Waste Interim Performance Assessment, HNF-EP-0884, Rev. 1, Fluor Daniel Hanford, Inc., Richland, Washington.

Mattichak, R. W., 1996a, Conceptual Design Letter Report for Project W-454, AW Jumper Manifold Upgrade, WHC-SD-W454-CDR-001, Rev. 0, Westinghouse Hanford Company, Richland, Washington.

Mattichak, R. W., 1996b, Functional Design Criteria for AW Jumper Manifold Upgrade 241-AW Tank Farm Project W-454, WHC-SD-W454-FDC-001, Rev. 1, Westinghouse Hanford Company, Richland, Washington. 
HNF-1901 REV 2

\section{Documents}

Moody, D. A., 1996, 241-AZ-101 Mixer Pump Support Assembly, Extension Riser, and Spray Wash System Design Verification, WHC-SD-W151-DA-005, Rev. 0, Westinghouse Hanford Company, Richland, Washington.

Nordquist, E. M., 1989, Conceptual Design Report, Tank Farm Ventilation Upgrade Cathodic Protection System, WHC-SD-W030-CDR-001, Rev. 0, Westinghouse Hanford Company, Richland, Washington. (Available in Project File only.)

Nordquist, E. M., 1995, Mixer Pump Test Specification Project W-151, WHC-SD-W151-TS-001, Rev. 0, Westinghouse Hanford Company, Richland, Washington.

Nordquist, E. M., 1996, Project W-151 Test Plan, WHC-SD-W151-TP-003, Rev. 0, Westinghouse Hanford Company, Richland, Washington.

Nordquist, E. M., 1997a, Cathodic Protection Acceptance Test Procedure, HNF-SD-W151-ATP-002, Rev. 1, Numatec Hanford Corporation for Fluor Daniel Hanford, Inc., Richland, Washington.

Nordquist, E. M., 1997b, Document Required for Acceptance for Beneficial Use of Project W-151, Tank 101-AZ Waste Retrieval System, HNF-SD-WM-ABU-023, Rev. 1, Numatec Hanford Corporation for Fluor Daniel Hanford, Inc., Richland, Washington.

Nordquist, E. M., 1997c, Project W-151 Checkout - Testing Report, HNF-SD-W151-TRP-003, Rev. 0, Numatec Hanford Corporation for Fluor Daniel Hanford, Inc., Richland, Washington.

Nordquist, E. M., 1997d, Project W-151 Project Field Verification Documentation, HNF-SD-W151-FVP-001, Rev. 0, as amended, Numatec Hanford Corporation for Fluor Daniel Hanford, Inc., Richland, Washington.

Nordquist, E. M., 1997e, Tank 101-AZ Waste Retrieval System Functional Design Criteria, HNF-SD-W151-FDC-001, Rev. 4, Numatec Hanford Corporation for Fluor Daniel Hanford, Inc., Richland, Washington.

Orme, R. M., 1999a, Waste Feed Delivery Technical Basis, Volume II, Addendum 1-1, "Waste Feed Delivery Flow Sheet for 241-AZ-101," HNF-1939, Rev. 0a, Numatec Hanford Corporation for Fluor Daniel Hanford, Inc., Richland, Washington.

Orme, R. M., 1999b, Waste Feed Delivery Technical Basis, Volume II, Addendum 2-1, "Waste Feed Delivery Flow Sheet for 241-AN-105," HNF-1939, Rev. 0b, Numatec Hanford Corporation for Fluor Daniel Hanford, Inc., Richland, Washington. 


\section{Documents}

Orme, R. M., 1999c, Waste Feed Delivery Technical Basis, Volume II, Addendum 3-1, "Waste Feed Delivery Flow Sheet for 241-AN-104," HNF-1939, Rev. Oc, prepared by Numatec Hanford Corporation for Fluor Daniel Hanford, Inc., Richland, Washington.

ORP, 1998, TWRS Privatization Contract, DE-AC06-RL13308, U.S. Department of Energy, Richland Operations Office, Richland, Washington.

ORP, 2000a, River Protection Project Mission Analysis Report, DOE/ORP-2000-10, Rev. 0, U.S. Department of Energy, Office of River Protection, Richland, Washington, Washington.

ORP, 2000b, DOE/ORP-2000-06 River Protection Project - Project Management Plan, DOE/ORP-2000-06, U.S. Department of Energy, Richland Operations Office, Richland

O'Toole, S. M., 2000, Systems Engineering Management Plan for the Tank Farm Contractor, HNF-SD-WM-SEMP-002, Rev. 2, CH2M HILL Hanford Group, Inc., Richland, Washington.

Pacquet, E. A., 1997, Project W-058 Startup Test Plan, HNF-SD-W058-SUP-002, Rev. 1, Numatec Hanford Corporation for Fluor Daniel Hanford, Inc., Richland, Washington.

Papp, I. G., 1998, Waste Feed Delivery Technical Basis, Volume II, "Waste Feed Delivery Flow Sheet," HNF-1939, Rev. 0, Numatec Hanford Corporation for Fluor Daniel Hanford, Inc., Richland, Washington.

Parazin, R. J., 1998a, Design Requirements Document for TWRS Privatization Phase 1 Liquid Effluent Transfer Systems, HNF-SD-WM-DRD-014, Rev. 1, as amended, Numatec Hanford Corporation for Fluor Daniel Hanford, Inc., Richland, Washington.

Parazin, R. J., 1998b, Design Requirements Document for TWRS Privatization Phase 1 Raw and Potable Water Supply Systems, HNF-SD-WM-DRD-015, Rev. 1, Numatec Hanford Corporation for Fluor Daniel Hanford, Inc., Richland, Washington.

Parazin, R. J., 1998c, Design Requirements Document for TWRS Privatization Phase 1 Site Development, , HNF-SD-WM-DRD-013, Rev. 2, Numatec Hanford Corporation for Fluor Daniel Hanford, Inc., Richland, Washington.

Parazin, R. J., 1998d, TWRS Privatization Phase 1, Master Site Plan, HNF-SD-TWR-DSD-001, Rev. 1, Numatec Hanford Corporation for Fluor Daniel Hanford, Inc., Richland, Washington.

Powell, P.A., 2000, Environmental Program Description for the Tank Farm Contractor, HNF-1773, Rev. 3, CH2M HLL Hanford Group, Inc., Richland, Washington. 


\section{Documents}

Rasmussen, J. E., 1997, "Radioactive Air Emissions Notice of Construction (NOC) Project W-314, Tank Farm Restoration and Safe Operations," (letter 97-EAP-760 to

A. W. Conklin, Washington State Department of Health and J. Leitch, U.S Environmental Protection Agency, December 8) U.S. Department of Energy, Richland Operations Office, Richland, Washington.

Rasmussen, O. R., 1999, Waste Feed Delivery Technical Basis, Volume III, "Waste Feed Delivery System Description," HNF-1939, Rev. OA, prepared by Lockheed Martin Hanford Corporation, Richland, Washington.

Raymond, R. E., 1998, Tank Waste Remediation System Technical Baseline Summary Description, HNF-2016, Rev. 0, Lockheed Martin Hanford Corporation for Fluor Daniel Hanford, Inc., Richland, Washington.

Reep, I. E., 1992, Conceptual Design Report Replacement of the Cross-Site Transfer, WHC-SD-W058-CDR-001, Rev. 0, Westinghouse Hanford Company, Richland, Washington.

Rieck, C. A., 1994, Conceptual Design Report, Initial Tank Retrieval Systems for Project W-211, WHC-SD-W211-CDR-001, Westinghouse Hanford Company, Richland, Washington.

Rieck, C. A., 1997a, Controlled Volume Metering Pump, Procurement Specification W211-AP24-P3, Rev. 0, Numatec Hanford Corporation for Fluor Daniel Hanford, Inc., Richland, Washington.

Rieck, C. A., 1997b, Diluent/Flush Pump, Procurement Specification W211-AP24-P5, Rev. 0, Numatec Hanford Corporation for Fluor Daniel Hanford, Inc., Richland, Washington.

Rieck, C. A., 1997c, Functional Design Criteria, Project W-211, Initial Tank Retrieval Systems, HNF-SD-W211-FDC-001, Rev. 3, Numatec Hanford Corporation for Fluor Daniel Hanford, Inc., Richland, Washington.

Rieck, C. A., 1997d, Mobile Water Heater/Boiler Package, Procurement Specification W211-AP24-P2, Rev. 0, Numatec Hanford Corporation for Fluor Daniel Hanford, Inc., Richland, Washington.

Rieck, C. A., 1997e, Steel Storage Tanks, Procurement Specification W211-AP24-P4, Rev. 0, Numatec Hanford Corporation for Fluor Daniel Hanford, Inc., Richland, Washington.

Rieck, C. A., 1998, Safety Assessment for Initial Tank Retrieval Systems-Project W-211, HNF-SD-W211-PSAD-001, Rev. 0, Numatec Hanford Corporation for Fluor Daniel Hanford, Inc., Richland, Washington. 


\section{Documents}

Rieck, C. A., and M. E. McKinney, 1996a, Retrieval Control System Enclosures, Procurement Specification W211-P3, Rev. 0, Numatec Hanford Corporation for Fluor Daniel . Hanford, Inc., Richland, Washington.

Rieck, C. A., and M. E. McKinney, 1996b, Waste Mobilization Mixer Pump, Procurement Specification W211-P005, Rev. 0, Numatec Hanford Corporation for Fluor Daniel Hanford, Inc., Richland, Washington.

Rieck, C. A., and M. E. McKinney, 1997, Procurement Specification, Slurry Transfer Pump, Specification W211-P001, Rev. 1, Numatec Hanford Corporation for Fluor Daniel Hanford, Inc., Richland, Washington.

Rifaey, S. H., 1998, Tank Waste Remediation System Engineering Plan, HNF-1947, Rev. 0, Lockheed Martin Hanford Corporation for Fluor Daniel Hanford, Inc., Richland, Washington.

RL, 1993, Hanford Facility Dangerous Waste Part A Permit Application, DOE/RL-88-21, as amended, U.S. Department of Energy, Richland Operations Office, Richland, Washington.

RL, 1996, Recommendation 93-5 Implementation Plan, DOE/RL 94-0001, U.S. Department of Energy, Richland Operations Office, Richland, Washington.

Shade, J. W., C. T. Kincaid, G. A. Whyatt, M. G. Piepho, K. Rhoads, J. A. Voogd, J. H. Westsik, M. D. Freshley, 1994, Performance Assessment of Grouted Double-Shell Tank Waste Disposal at Hanford, WHC-SD-WM-EE-004, Rev. 1, Westinghouse Hanford Company, Richland, Washington.

Shade, J. W., 1997, TWRS Phase I Privatization Site Environmental Baseline and Characterization Plan, HNF-SD-TWR-EV-001, Rev. 0, prepared by Numatec Hanford Corporation for Fluor Daniel Hanford, Inc., Richland, Washington.

Shaw, C. P., 1992, Mixer Pump Study for Project W-151, WHC-SD-WM-ES-195, Rev. 0, Westinghouse Hanford Company, Richland, Washington.

Singh, G., 1997a, Conceptual Design Report, TWRS Privatization Phase I, Electrical Power System Subproject W-503, HNF-SD-W503-CDR-001, Rev. 0, Numatec Hanford Corporation for Fluor Daniel Hanford, Inc., Richland, Washington.

Singh, G., 1997b, Conceptual Design Report, TWRS Privatization Phase 1, Liquid Effluent Transfer Systems Subproject W-506, HNF-SD-W506-CDR-001, Rev. 0, Numatec Hanford Corporation for Fluor Daniel Hanford, Inc., Richland, Washington. 


\begin{tabular}{|c|}
\hline Documents \\
\hline $\begin{array}{l}\text { Singh, G., 1997c, Conceptual Design Report, TWRS Privatization Phase I, Raw and Potable } \\
\text { Water, Subproject W-504, HNF-SD-W504-CDR-001, Rev. 0, Numatec Hanford } \\
\text { Corporation for Fluor Daniel Hanford, Inc., Richland, Washington. }\end{array}$ \\
\hline $\begin{array}{l}\text { Singh, G., 1997d, Conceptual Design Report, TWRS Privatization Phase 1, Site Development } \\
\text { and Roads, Subproject W-505, HNF-SD-W505-CDR-001, Rev. 0, Numatec Hanford } \\
\text { Corporation for Fluor Daniel Hanford, Inc., Richland, Washington. }\end{array}$ \\
\hline $\begin{array}{l}\text { Singh, G., 1997e, Design Requirements Document, Design Requirements for the Phase } 1 \\
\text { Privatization Electrical Power System, WHC-SD-WM-DRD-011, Rev. 1, Numatec } \\
\text { Hanford Corporation for Fluor Daniel Hanford, Inc., Richland, Washington. }\end{array}$ \\
\hline $\begin{array}{l}\text { Singh, G., and D. L. Fort, 1997, Summary Conceptual Design Report for Tank Waste } \\
\text { Remediation System Privatization Phase } 1 \text { Infrastructure Support, Project W-519, } \\
\text { HNF-1938, Rev. 0, Numatec Hanford Corporation for Fluor Daniel Hanford, Inc., } \\
\text { Richland, Washington. }\end{array}$ \\
\hline $\begin{array}{l}\text { Smith, D. F., and T. J. Conrads, 2000, Functional Analysis for Double-Shell Tank Subsystems, } \\
\text { HNF-5136, Rev. 0, Numatec Hanford Corporation for CH2M HILL Hanford Group, Inc., } \\
\text { Richland, Washington. }\end{array}$ \\
\hline $\begin{array}{l}\text { Staehr, T. W., 1999, Mixer Pump Test Plan for Double-Shell Tank AZ-101, } \\
\text { HNF-SD-WM-PTP-027, Rev. 4, as amended, COGEMA Engineering Corporation for } \\
\text { Fluor Daniel Hanford, Inc., Richland, Washington. }\end{array}$ \\
\hline $\begin{array}{l}\text { Taylor, W. J., 1998, “Contract No. DE-AC06-96RL13200 - Waste Disposal Division (WDD) } \\
\text { Multi-Year Work Plan (MYWP) Update Guidance for Fiscal Year } 1999 \text { (FY99),” } \\
\text { (letter 98-WDD-103 to R. D. Hanson, Fluor Daniel Hanford, Inc., September 21), } \\
\text { U.S. Department of Energy, Richland Operations Office, Richland, Washington. }\end{array}$ \\
\hline $\begin{array}{l}\text { Tollefson, K. S., and R. D. Potter, 2000, Waste Feed Delivery Environmental Permits and } \\
\text { Approvals Plan, HNF-2401, Rev. 1, CH2M HILL Hanford Group, Inc., } \\
\text { Richland, Washington. }\end{array}$ \\
\hline $\begin{array}{l}\text { Troyer, G. L., 1995, Project W-151 Flexible Receiver Radiation Detector System Acceptance } \\
\text { Test Plan, WHC-SD-W151-ATP-001, Rev. 1, Westinghouse Hanford Company, } \\
\text { Richland, Washington. }\end{array}$ \\
\hline $\begin{array}{l}\text { Warnick, T. L., 1997a, Project W-314 AB Valve Pit Upgrade Acceptance for Beneficial Use, } \\
\text { HNF-SD-W314-ABU-009, Rev. 0, Fluor Daniel Northwest for Fluor Daniel } \\
\text { Hanford, Inc., Richland, Washington. }\end{array}$ \\
\hline $\begin{array}{l}\text { Warnick, T. L., 1997b, Project W-314 AX-B Valve Pit Upgrade Acceptance for Beneficial Use, } \\
\text { HNF-SD-W314-ABU-005, Rev. 0, Fluor Daniel Northwest for Fluor Daniel } \\
\text { Hanford, Inc., Richland, Washington. }\end{array}$ \\
\hline
\end{tabular}




\section{Documents}

Warnick, T. L., 1997c, Project W-314 AZ-02A Pump Pit Upgrade Acceptance for Beneficial Use, HNF-SD-W314-ABU-007, Rev. 0, Fluor Daniel Northwest for Fluor Daniel Hanford, Inc., Richland, Washington.

Warnick, T. L., 1997d, Project W-314 Master Pump Shutdown Upgrade Acceptance for Beneficial Use, HNF-SD-W314-ABU-001, Rev. 0, Fluor Daniel Northwest for Fluor Daniel Hanford, Inc., Richland, Washington.

Warnick, T. L., 1997e, Project W-314 SN-630 Transfer Line (AZ-02A to AN-B) Acceptance for Beneficial Use, HNF-SD-W314-ABU-004, Rev. 0, Fluor Daniel Northwest for Fluor Daniel Hanford, Inc., Richland, Washington.

Warnick, T. L., 1997f, Project W-314 SN-634 Transfer Line (AB to AX-B) Acceptance for Beneficial Use, HNF-SD-W314-ABU-008, Rev. 0, Fluor Daniel Northwest for Fluor Daniel Hanford, Inc., Richland, Washington.

Warnick, T. L., 1997g, Project W-314 SN-632 Transfer Line (AX-B to AZ-02A) Acceptance for Beneficial Use, HNF-SD-W314-ABU-006, Rev. 0, Fluor Daniel Northwest for Fluor Daniel Hanford, Inc., Richland, Washington.

Weir, W. R., 2000, Configuration Management Plan for the Tank Farm Contractor, HNF-1900, Rev. 1, CH2M HLL Hanford Group Inc., Richland, Washington.

Winkelman, W. D., M. R. Adams, T. M. Brown, J. W. Hunt, D. J. McCain, and L. J. Fergestrom, 1997, Fiscal Year 1997 - 1998 Waste Information Requirements Document, HNF-SD-WM-PLN-126, Rev.0, as amended, Lockheed Martin Hanford Corporation for Fluor Daniel Hanford, Inc., Richland, Washington.

Zaman, S. H., 1999, TWRS Facility Safety Equipment List, HNF-SD-WM-SEL-040, Rev. 4, as amended, Lockheed Martin Hanford Corporation, Richland, Washington.

Ziada, A. H., 1993, Stress Analysis of 4- to 6-Inch and 42-Inch Flexible Receiver, WHC-SD-W151-DA-003, Rev. 0, Westinghouse Hanford Company, Richland, Washington.

Ziada, A. H., 1994, W-151 Mixer Pump Energy Absorption Cylinder Analysis, WHC-SD-W151-DA-004, Rev. 0, Westinghouse Hanford Company, Richland, Washington. 


\section{HNF-1901 REV 2}

This page intentionally left blank. 